\title{
Environmental Summary of the F- and H-Area Seepage Basins Groundwater Remediation Project, Savannah River Site
}

by

G. P. Friday

Westinghouse Savannah River Company

Savannah River Site

Aiken, South Carolina 29808

RECEIVED

JAN 301998

OSTI

This paper was prepared in connection with work done under the above contract number with the U.S. Department of Energy. By acceptance of this paper, the publisher and/or recipient acknowledges the U.S. Government's right to retain a nonexclusive, royalty-free license in and to any copyright covering this paper, along with the right to reproduce and to authorize others to reproduce all or part of the copyrighted paper. 
WSRC-TR-97-0130

\section{ENVIRONMENTAL SUMMARY OF THE F- AND H- AREA SEEPAGE BASINS GROUNDWATER REMEDIA- TION PROJECT, SAVANNAH RIVER SITE}

G.P. Friday

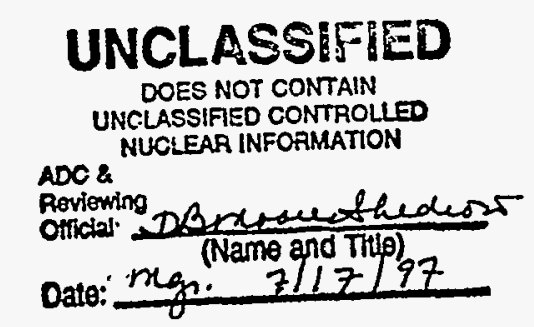

Westinghouse Savannah River Company

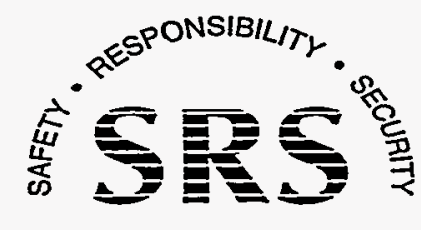
Savannah River Site Aiken, South Carolina 29808 


\section{Disclaimer}

\section{DISCLAIMER}

This report was prepared as an account of work sponsored by an agency of the United States Government. Neither the United States Government nor any agency thereof, nor any of their employees, makes any warranty, express or implied, or assumes any legal liability or responsibility for the accuracy, completeness, or usefulness of any information, apparatus, product, or process disclosed, or represents that its use would not infringe privately owned rights. Reference herein to any specific commercial product, process, or service by trade name, trademark, manufacturer, or otherwise does not necessarily constitute or imply its endorsement, recommendation, or favoring by the United States Government or any agency thereof. The views and opinions of authors expressed herein do not necessarily state or reflect those of the United States Government or any agency thereof.

This report has been reproduced directly from the best available copy.

Available to DOE and DOE contractors from the Office of Scientific and Technical Information, P.O. Box 62, Oak Ridge, TN 37831; prices available from (615) 576-8401.

Available to the public from the National Technical Information Service, U.S. Department of Commerce; 5285 Port Royal Road, Springfield, VA 22161.

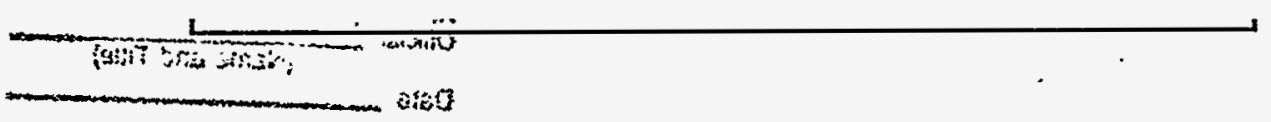




\section{DISCLAIMER}

Portions of this document may be illegible electronic image products. Images are produced from the best available original document. 


\section{TABLE OF CONTENTS}

$\underline{\text { Section }}$

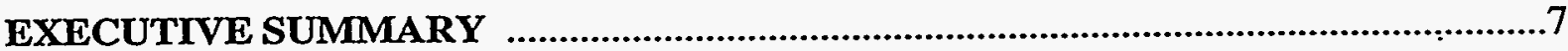

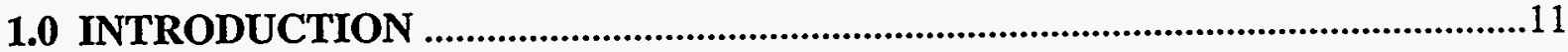

1.1 Background ......................................................................................................11

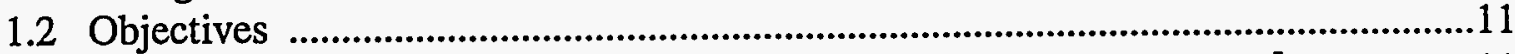

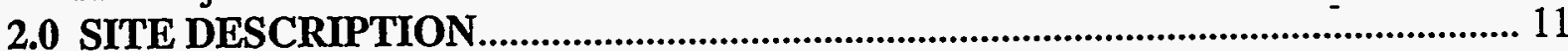

$2.1 \mathrm{~F}$-and $\mathrm{H}-\mathrm{Area}$ Seepage Basins and History of Operations ..........................................11

2.2 Description of the Environment ..................................................................................13

3.0 BASELINE ENVIRONMENT OVERVIEW ............................................................14

3.1 Abiotic Investigations ........................................................................................... 14

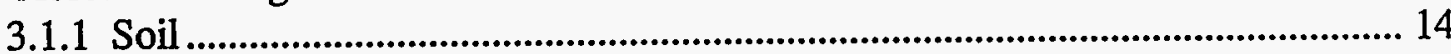

3.1.2 Sediment .............................................................................................. 15

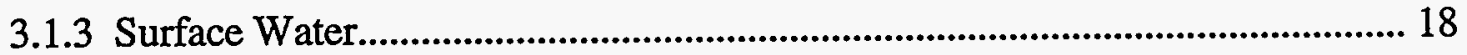

3.1.4 Water Table Monitoring ................................................................................... 30

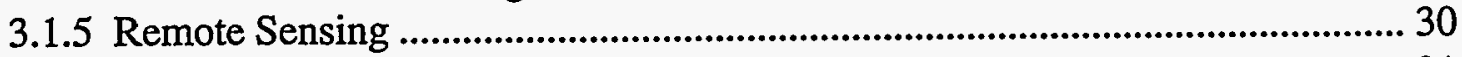

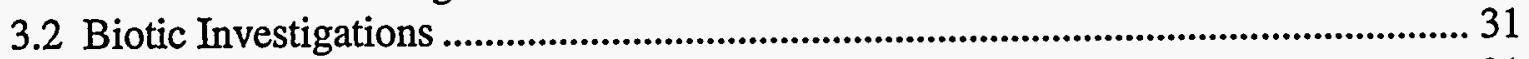

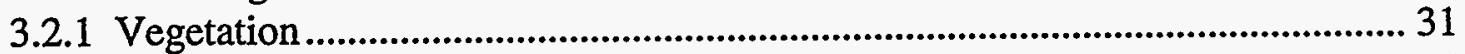

3.2.2 Macroinvertebrates ........................................................................................ 36

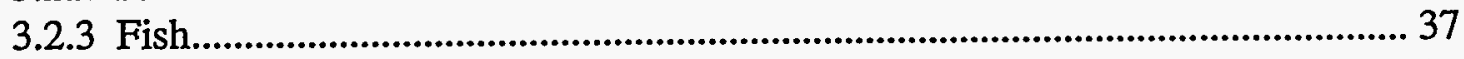

3.2.4 Herpetofauna and Small Mammals.................................................................... 37

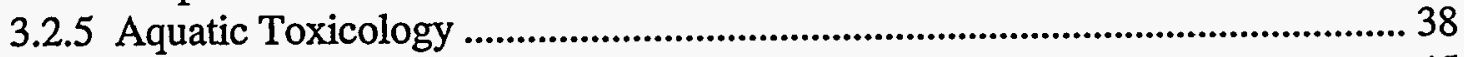

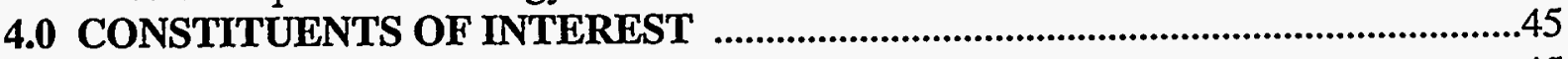

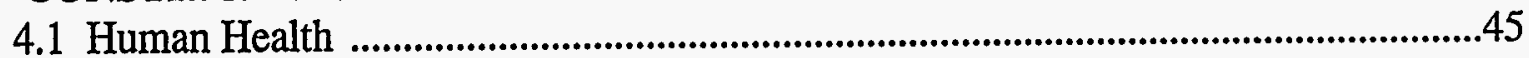

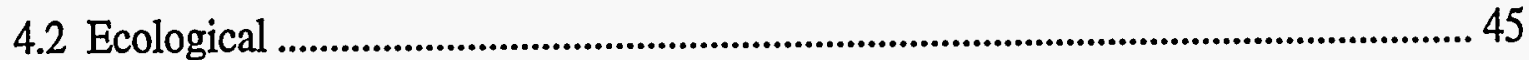

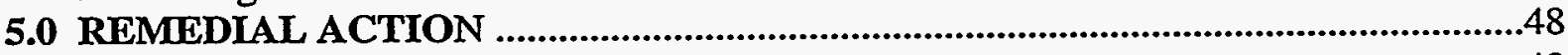

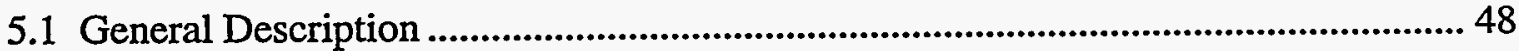

5.2 Potential Environmental Effects ................................................................................49

5.3 Evaluating the Remedial Action ................................................................................48

6.0 SUMMARY AND CONCLUSIONS ..........................................................................5 52

6.1 Baseline Environment ...........................................................................................52

6.2 Constituents of Interest ..................................................................................... 53

6.3 Remedial Action ...................................................................................................... 54

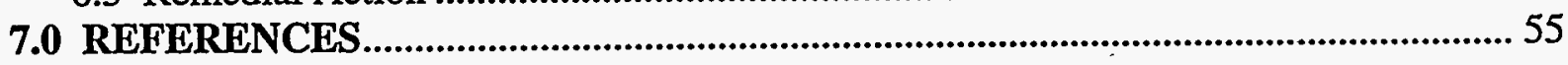

\section{APPENDICES}

A - Coordinates for Sampling and Well Locations.......................................................... A-1

B - Sediment and Surface Water Statistics for 1995 and 1996............................................ B-1

C - Piezometer Data, January-August 1996........................................................................... - 


\section{LIST OF TABLES}

Table

Page

1 Radioactivity (pCi/g dry wt) in surficial soil (0-8 cm depth) at F- and H-Areas, 1995. .15

2 List of constituents in sediment that exceeded background and ecological screening values, 1995 . .17

3 Semi-annual sampling locations for surface water, 1989-1996.

4 Constituents in surface water whose 95\% UCI exceeded background, ecological, and human health benchmarks at Fourmile Branch (FMB) and the F-and H-Area seeplines, 1995.

5 Constituents in surface water along the Old F-Area Effluent Ditch that exceeded Primary Drinking Water Standards or Maximum Contaminant Levels, 1994-1996.

6 Mean radioactivity $(\mathrm{pCi} / \mathrm{mL})$ and $95 \%$ upper confidence intervals (UCI) of tritium at the F-and H-Area Seeplines and Fourmile Branch, 1989-1996....... 25

7 Mean conductivity $(\mu \mathrm{S} / \mathrm{cm})$ and $95 \%$ upper confidence intervals (UCI) at the F-and H-Area Seeplines and Fourmile Branch, 1989-1996................................28

8 Germination (\%) and root elongation (mm) results, 1990-1994. ..........................33

9 Body burdens of selected constituents in shrews (Blarina carolinensis) in the vicinity of the FHSB, 1995. ...................................................................38

10 Distribution of aquatic toxicity sampling locations, $1990-1994$. .........................39

11 No Observed Effect Concentrations (NOECs) for Toxicity Testing Locations, 1990-1994.

12 Constituents of interest to human health in water as identified from three screening protocols. . .46

13 Ecological constituents of interest in sediment and surface water. .......................47

A-1 Sediment sampling locations and SRS site coordinates, 1995. ........................ A-2

A-2 Surface water sampling locations and SRS site coordinates, 1989-1996......... A-3

A-3 SRS site coordinates for piezometers in the F-and $\mathrm{H}$-Areas. ............................A-4

A-4 Site grid coordinates used to delineate jurisdictional wetlands, 1993. .............. A-5

A-5 Toxicity sampling locations and site grid coordinates, 1990-1994. .................. A-15

A-6 Coordinates for Extraction and Injection Wells at F-Area. ............................ A-16

A-7 Coordinates for Extraction and Injection Wells at $\mathrm{H}$-Area. ........................... A-17

B-1 Mean concentration and 95\% upper confidence intervals (UCI) of non-radiological constituents in sediment, 1995.

B-2 Mean radioactivity ( $\mathrm{pCi} / \mathrm{g}$ ) and $95 \%$ upper confidence intervals (UCI) of radioisotopes in sediment, 1995.

B-3 Mean concentrations $(\mu \mathrm{g} / \mathrm{L})$ and $95 \%$ upper confidence intervals of non-radiological constituents in surface water, 1995.

B-4 Mean radioactivity ( $\mathrm{pCi} / \mathrm{L}$ ) and $95 \%$ upper confidence intervals (UCL) for radiological constituents in surface water, 1995. B-6

B-5 Mean concentration $(\mu \mathrm{g} / \mathrm{L})$ and $95 \%$ upper confidence intervals of non-radiological constituents in surface water, 1996. B-8

B-6 Mean radioactivity (pCi/L) and 95\% upper confidence intervals (UCL) for radionuclides constituents in surface water 1996. 


\section{LIST OF TABLES (Cont.)}

Table

C-1 Construction information for the $\mathrm{F}$ - and $\mathrm{H}$-Area wetlands piezometer network.

C-2 Monthly Water Level Measurements, January-August, 1996.

C-3

C-3 Water Level Measurements for the Period of January 1996 to August 1996.... C-4 


\section{LIST OF FIGURES}

Figure

Page

1 General Site Map of the F- and H-Area and Fourmile Branch, Savannah River Site. . .12

2 Distribution of sediment and surface water sampling locations, $1995 \ldots \ldots \ldots . . . . . . . .16$

3 The Savannah River Site showing the location of Fourmile Branch. ...................18

$4 \quad$ Flow Measurement Stations 01 and 02, Fourmile Branch. ...................................19

5 Maximum, mean, and minimum flow measurements at Station 01. ....................19

6 Maximum, mean, and minimum flow measurements at Station 02. .................... 20

7 Distribution of surface water sampling locations, 1989-1996............................ 21

8 Mean radioactivity ( $\mathrm{pCi} / \mathrm{mL}$ ) and $95 \%$ confidence intervals of tritium at the F-Area Seepline, 1989-1996.

9 Mean radioactivity $(\mathrm{pCi} / \mathrm{mL})$ and $95 \%$ confidence intervals of tritium at the H-Area Seepline, 1989-1996.

10 Tritium radioactivity $(\mathrm{pCi} / \mathrm{mL})$ at the $\mathrm{F}$-and $\mathrm{H}$-Area Seeplines and Fourmile Branch, 1989-1996.

11 Boxplots for $\mathrm{pH}$ at the F-and H-Area Seeplines and Fourmile Branch, 1989-1996.

12 Mean and 95\% confidence interval of conductivity $(\mu S / \mathrm{cm})$ at the F-Area Seepline, 1989-1996.

13 Mean and $95 \%$ Confidence Intervals $(95 \%)$ of conductivity $(\mu \mathrm{S} / \mathrm{cm})$

at the H-Area Seepline, 1989-1996.

14 Distribution of piezometers at the F-and H-Area Seeplines.

15 Distribution of jurisdictional wetlands below the $\mathrm{F}$-and $\mathrm{H}$-Areas as determined by field surveys in 1993. 32

Percent survival of seedlings in four wetland areas, 1994-1996.

Distribution of toxicity sampling locations, 1990-1994.

Distribution of extraction and injection wells for F-Area. 


\title{
Executive Summary
}

From 1955 to 1988, the F-and H-Area facilities discharged hazardous and radioactive chemicals into seven seepage basins, contaminating the underlying soils and upper aquifers. These radioactive and chemical contaminants continue to migrate via the groundwater, eventually surfacing in the wetlands of Fourmile Branch, a tributary of the Savannah River. The basins were certified closed in 1991 in accordance with RCRA regulations which also stipulated continued monitoring of the groundwater. In 1992, the State_of South Carolina Department of Health and Environmental Control (SCDHEC) issued a RCRA Part B postclosure care permit that required a corrective action plan to remediate groundwater contamination. The remedial action seeks to remove the contamination by extracting groundwater using extraction wells, treating the water using reverse osmosis technology, and injecting the treated water back into the aquifer. This report summarizes the results of nearly 70 investigations of the baseline environment, describes the remedial action, and identifies constituents of interest that pose potential risk to human health and the environment. It also proposes an approach for evaluating the effectiveness of the remedial action.

\section{Characterization of the Baseline Environment}

\begin{abstract}
Abiotic Investigations
Abiotic investigations have included sampling and analyses of soil, sediment, and surface waters. Studies of soil and sediment in the vicinity of the F- and H-Areas have been performed primarily as part of the routine monitoring and surveillance efforts reported in annual SRS environmental reports. In soil, elevated concentrations of antimony and zinc were reported. Radioisotopes of cesium, plutonium, and strontium were also found in soils. The maximum radioactivity was $1.01 \mathrm{pCi} / \mathrm{g}$ of Cs-137 near H-Area in 1994 and 1995. The most recent and comprehensive sampling and analyses of sediment near the seepage basins occurred in 1995 . The majority of non-radiological constituents had concentrations that exceeded background levels. Fourmile Branch had four constituents whose 95\% upper confidence intervals exceeded EPA thresholds. Arsenic was the only constituent that exceeded threshold levels at both seeplines and Fourmile Branch. Although no radiological screening values have been issued by EPA, tritium had the highest radioactivity of the constituents that were measured. The mean tritium activity ranged from $82 \mathrm{pCi} / \mathrm{g}$ at the H-Area seepline to $289 \mathrm{pCi} / \mathrm{g}$ in Fourmile Branch.
\end{abstract}

Surface water in the vicinity of the seepage basins consists primarily of the waters of Fourmile Branch and shallow pools associated with the seeplines. The average flow of Fourmile Branch from 1977 to 1991 at Road A-12 was $5.9 \mathrm{~m}^{3} / \mathrm{s}\left(208 \mathrm{ft}^{3} / \mathrm{s}\right)$. Surface water associated with the seeplines varies seasonally and is influenced by precipitation and water elevation of the Savannah River. Three programs were initiated in the 1990's to examine surface water chemistry: (1) semi-annual sampling of the F- and H-Area seeplines and Fourmile Branch for metals, radionuclides, volatile compounds, inorganic constituents and physical parameters, (2) quarterly surveys of tritium, $\mathrm{pH}$, and specific electrical conductance at both seeplines, and (3) quarterly sampling of wetland surface waters along the old F-Area effluent ditch for tritium and volatile organic compounds.

Semi-Annual Program - Results of the semi-annual sampling program indicated that surface waters at the F- and H-Area seeplines and Fourmile Branch contained contaminants associated with the seepage basins. Analytical results from the 1996 sampling program are incomplete. However, based on the results of the 1995 sampling effort, 25 non-radiological constituents had concentrations that exceeded both human health and ecological benchmarks. Radioisotopes whose activity levels exceeded drinking water standards or maximum concentration levels were Cs-137, I-129, Np-237, Ra-228, Sr-90, tritium, and U-238.

Tritium Program - Tritium, $\mathrm{pH}$, and specific electrical conductance were measured in surface water at both seeplines in 1989 and also from 1992 to 1996. Water samples were taken from Fourmile Branch since 1992. Tritium levels at both seeplines and Fourmile Branch have declined since the initial sampling events. The mean radioactivity of tritium at the F-Area seepline declined from $3357 \mathrm{pCi} / \mathrm{mL}$ in 1989 to $1484 \mathrm{pCi} / \mathrm{mL}$ in 1996. Mean radioactivity of tritium at the H-Area seepline declined from $8402 \mathrm{pCi} / \mathrm{mL}$ in 1989 to $994 \mathrm{pCi} /$ 
mL in 1996. From 1992 to 1996, the mean radioactivity of tritium in Fourmile Branch ranged from $853 \mathrm{pCi}$ $\mathrm{mL}$ in 1992 to $145 \mathrm{pCi} / \mathrm{mL}$ in 1996. Since 1989, the radioactivity of tritium at both seeplines and Fourmile Branch markedly exceeded the drinking water standard of $20 \mathrm{pCi} / \mathrm{mL}$; levels were highest at the H-Area seepline, intermediate at the F-Area seepline, and lowest in Fourmile Branch.The pH of surface water at the seeplines and Fourmile Branch ranged between 2.9 and 7.0 from 1989 to 1996 . This compares to a range of between 6.0 and 8.5 for groundwater within the United States and 4.9 to 7.7 for the coastal plain of South Carolina. Median $\mathrm{pH}$ values were lowest at the $\mathrm{F}$-Area seepline, intermediate at the H-Area seepline, and highest in Fourmile Branch. Specific electrical conductance provides an indication of ion concentration and has been used as a general indicator of plume differentiation between the seepage basins and the burial ground at SRS. From 1989 to 1996 , the mean conductivity ranged from $65 \mu \mathrm{S} / \mathrm{cm}$ in Fourmile Branch to $354 \mu \mathrm{S} / \mathrm{cm}$ at the F-Area seepline. Conductivity and tritium radioactivity were correlated at both seeplines.

Old F-Area Ditch -Results of surface water sampling showed that tritium and volatile organic compounds, presumably from the old burial ground, had migrated to the wetlands along the old F-Area ditch. In addition to tritium, 1,2-dichloroethylene, tetrachloroethylene, trichloroethylene, and vinyl chloride had concentrations that exceeded primary drinking water standards or maximum contaminant levels from 1994 to 1996.

Piezometers - To further characterize the baseline environment, a network of 20 piezometers (12 in F-Area and 8 in H-Area) was installed in January and May 1996. The objective of this program was to establish baseline hydraulic head data and to permit the monitoring of water table elevations before, during, and after remedial action. From January to August 1996, water table levels were relatively stable. Additional piezometers will be established in a reference area in 1997 so that changes in water table behavior attributable to natural processes can be distinguished from those that might be attributable to the extraction wells.

\section{Biotic Investigations}

Biotic investigations have included studies of the flora, fauna, and aquatic toxicity near the seepage basins and Fourmile Branch. In the spring of 1993, the jurisdictional wetlands downgradient from the seepage basins and north of Fourmile Branch were delineated and mapped in accordance with U.S. Army Corps of Engineers protocol. In addition to being ecologically and hydrologically important, wetlands are protected by several regulations and executive orders. There is a policy of "not net loss" of wetlands at the SRS.

Vegetative stress and mortality of bottomland hardwood forest in the wetlands was observed in 1988, and appears to be a result of chemical contaminants in the substrate, altered hydrology, and drought. A series of studies, including seed germination and revegetation investigations, was initiated to assess vegetative conditions and potential impacts to the wetlands along Fourmile Branch. Seed germination studies of toxicity in seepline soil leachates showed reduced effects over time on lettuce seed germination and growth as compared to control samples from an uncontaminated site. This implies that natural water transport reduced soil toxicity, and that further reductions in contaminant concentrations are possible with subsequent hydrological events. Revegetation of stressed areas by natural succession has been poor or marginal in both F- and H-Areas. An effort to test the ability of the impacted wetlands to sustain growth of the native tree species was initiated in 1994. In an effort to reestablish the climax species of the area, swamp tupelo seedlings were planted in four areas along the seepline. Percent survival of tupelo seedlings generally declined in three areas from 1994 to 1996.

Studies of macroinvertebrates in 1993 indicated stressed environmental conditions in Fourmile Branch. These were due to low dissolved oxygen concentrations rather than discharges from the seepage basins. In 1995, macroinvertebrate communities in Fourmile Branch near Road C were perturbed compared to other SRS streams even though oxygen levels were near acceptable limits. Species diversity of fish in Fourmile Branch was similar to other SRS sites, but analysis of fish tissue contained metals including aluminum, chromium, mercury, selenium, and zinc. Comprehensive studies are scheduled for 1997. Body burdens of constituents in shrews captured in 1995 were generally higher in the vicinity of the basins than at background locations.

Since 1990 , a series of aquatic toxicity studies was performed at 11 seepline locations and five locations in 
Fourmile Branch. In addition, surface water from five reference locations was also tested. Of the eleven seepline locations that were sampled in 1993 and 1994, only two showed no evidence of toxicity. The remaining seepline locations showed toxic responses on at least one occasion. Notably, the degree of toxicity appeared to vary temporally, likely as a result of rainfall which would dilute the concentrations of toxic constituents at the seepline. Concurrent sampling of reference seepline locations that were not influenced by any known source of contamination also showed a high percentage of toxic responses, thus indicating that unimpacted groundwater in portions of the SRS is toxic to the standard test organism. However, the reference locations were generally less toxic than the F-and H-Area seeplines. Of the tests conducted between 1990 and 1994, only a single test conducted on Fourmile Branch showed evidence of toxicity.This indicated that the groundwater discharging into the wetlands down gradient from the F- and H-Area seepage basins was not producing toxic responses in the receiving stream, Fourmile Branch.

Toxicity Identification Evaluations- The toxicity testing conducted at the seeplines from 1990 through 1994 produced reasonably consistent results indicating that some component of the groundwater in both this region of the SRS, and at reference locations, was causing toxic responses. In 1995, the SRS performed a Toxicity Identification and Evaluation (TIE) at the seepline to determine which constituents were causing the observed responses. The results of the testing for the F-Area seepline indicated that aluminum and cadmium were the most likely contributors to the toxic response, with naturally occurring iron as an additional potential contributor. At the H-Area seepline, the results of the TIE were inconclusive, but the results suggested the presence of a volatile toxicant. Testing further indicated that toxicity at the H-Area seepline had declined over time. Testing at a reference seepline location and Fourmile Branch indicated that naturally high levels of iron in ground water were responsible for the toxicity at both locations. Elevated aluminum and cadmium concentrations at the F-Area seepline are either a result of historic discharges to the basin or, more likely, a result of leaching of these constituents from the soil matrix by the acidic groundwater conditions under the basins. The nature and source of the volatile constituent in the H-Area seepline waters is unresolved, but might be due to elevated concentrations of ammonia.

\section{Constituents of Interest}

Because this report summarizes several investigations that have used different screening protocols, chemicals potentially posing risk to the environment were broadly categorize as "constituents of interest." These included constituents that met the following criteria: (1) they were identified as a constituent of potential concern in the screening level risk assessment for the F- and H-Area groundwater unit, (2) they were identified as being of concern by an independent peer review, or (3) concentrations exceeded a regulatory threshold value such as the primary and secondary drinking water standards, EPA Region III risk-based concentrations, or an ecological screening value issued by EPA Region IV. Non-radiological constituents of interest to human health or the environment in surface water included aluminum, antimony, arsenic, beryllium, cadmium, chloride, copper, iron, manganese, mercury, nitrate, nitrite, silver, and thallium. Radiological constituents of interest to human health or the environment in surface water included americium-241, carbon-14, cesium-137, curium-243, iodine-129, radium-226, radium-228, strontium-90, technetium-99, tritium, and uranium-238. Ecological constituents of interest in sediment were arsenic, cadmium, chromium, copper, iron, lead, mercury, nickel, and silver. Because screening levels for sediment have not been issued for human health, sediment constituents of interest could not be identified. The concentrations of all constituents varied by area and by year. The constituents listed above are comprehensive based on studies to date and should receive consideration for future monitoring studies and risk assessment.

\section{Remedial Action}

The remedial action that is proposed for the F-and H-Areas consists of a pump-and-treat technology that utilizes reverse osmosis. Under this scenario, extraction wells would pump contaminated groundwater to the surface for treatment. The treatment system will reduce heavy metals, nitrates, and some radionuclides to groundwater protection standards. Although tritium cannot be removed by this approach, the well system is designed to control seepage into the wetlands by the groundwater. The treated water, which would retain radioactive tritium, would be reinjected into the aquifer until the tritium decays naturally to acceptable levels. Potential effects associated with this remedial action include alteration of wetland and aquatic habitat. 
Environmental Summary

WSRC-TR-97-0130 


\subsection{Introduction}

With the ending of the cold war, the mission of the Savannah River Site (SRS) changed from one of producing nuclear defense materials to facility decontamination, environmental restoration, and waste management. In response to the Resource Conservation and Recovery Act (RCRA) and Superfund Reauthorization Act (SA$\mathrm{RA}$ ), environmental restoration became one of the principal programs at SRS. Its goal is to safely and costeffectively remediate inactive waste and groundwater units while managing risk and protecting human health and the environment.

Radiological and non-radiological materials have been used at facilities and laboratories throughout the SRS. Perhaps the most important was the General Separations Area (GSA), an industrial complex comprised of FArea, $\mathrm{H}$-Area, and the Burial Ground Complex. The F-and $\mathrm{H}$-Area facilities discharged hazardous and radioactive materials into seven seepage basins from 1955 to 1988, contaminating,the underlying soils and aquifers. Although the seepage basins are currently inactive, radioactive and chemical contaminants migrate via the groundwater, eventually reaching the surface in the wetlands of Fourmile Branch; a tributary of the Savannah River. This report summarizes what is known about the baseline environment, describes the remedial action, and identifies constituents that pose potential risk to human health and the environment.

\subsection{Background}

Environmental studies have been conducted in the vicinity of the F-and H-Area Seepage Basins (FHSB) since the 1960's. The basins were certified closed in 1991 in accordance with RCRA regulations which also stipulated continued monitoring of the groundwater. In 1992, the State of South Carolina Department of Health and Environmental Control (SCDHEC) issued a RCRA Part B postclosure care permit that required a corrective action plan to remediate groundwater contamination. The remedial action seeks to remove the contamination by extracting groundwater using extraction wells, treating the water using reverse osmosis technology, and injecting the treated water back into the aquifer.

\subsection{Objectives}

The principal goal of this report is to summarize existing information pertaining to the baseline environment at FHSB. Characterization of the baseline environment is based on data and information collected in the 1990's. Specific objectives include the following:

- comprehensively identify existing environmental data and characterize the baseline environment

- summarize the results of abiotic and biotic investigations that have been conducted to date

-identify constituents of potential interest

- describe potential impacts to the environment from the proposed remedial action

-identify performance measures that can be used to gauge the effectiveness of remedial action

\subsection{Site Description}

\subsection{F-and $\mathbf{H}$-Area Seepage Basins and History of Öperations}

The FHSB consists of seven seepage basins located within the General Separations Area of the SRS (Figure 1). The basins, which occupy approximately 9 ha (23 acres), have been covered with impermeable clay caps and closed under RCRA authority. The nearest stream, Fourmile Branch, is located approximately $400 \mathrm{~m}$ $(1300 \mathrm{ft}$ ) from the H-Area Basins and approximately $600 \mathrm{~m}$ (1970 ft) from the F-Area Basins. The Savannah River is located approximately $13 \mathrm{~km}$ (8 miles) from the FHSB. 


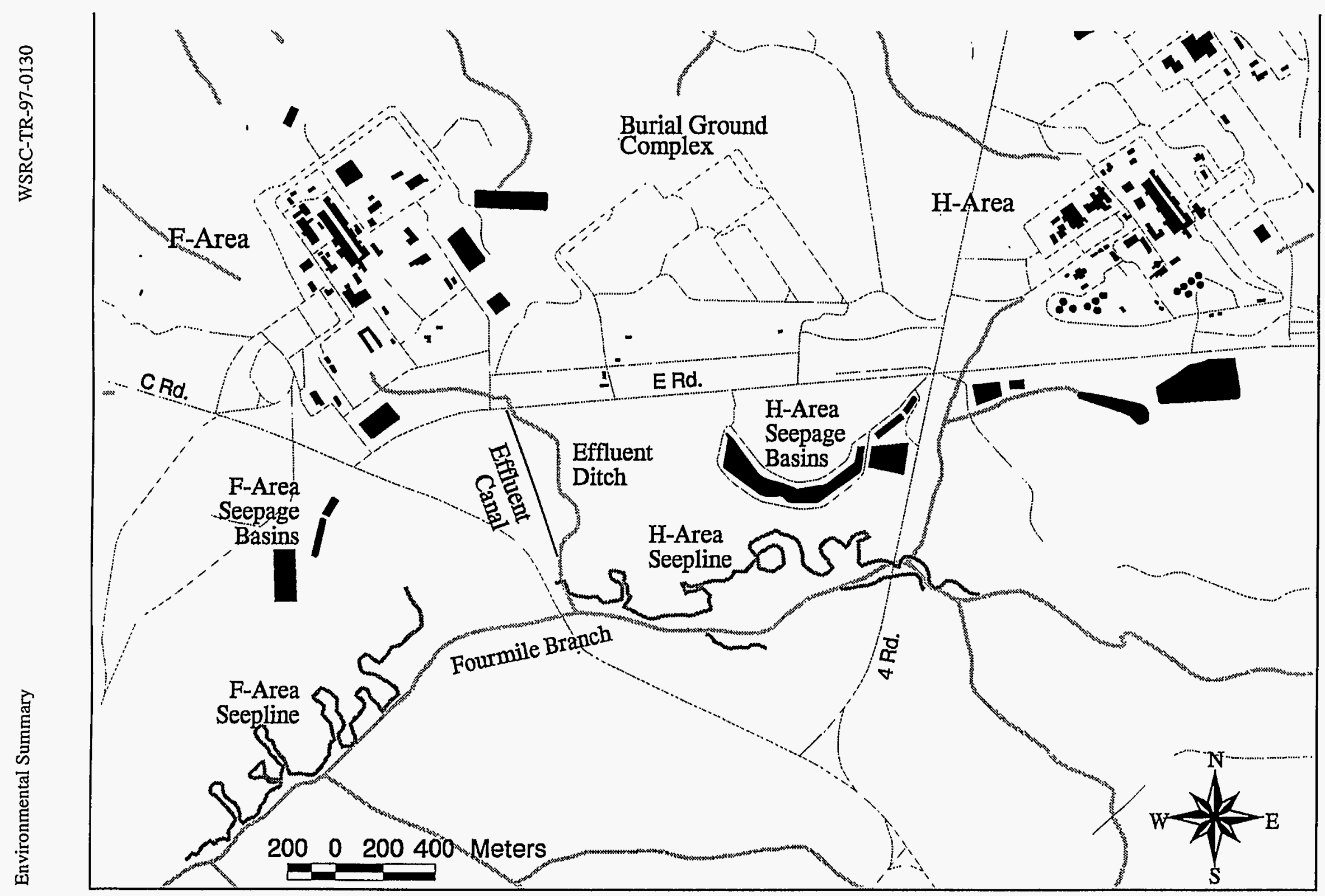

FIGURE 1. General Site Map of the F- and H-Area and Fourmile Branch, Savannah River Site. 
The FHSB consists of two principal areas: (1) the western area which contains the three F-Area Seepage Basins and (2) the eastern area which contains four H-Area Seepage Basins. The F-Area basins cover approximately 7 acres whereas the $\mathrm{H}$-Area basins cover approximately 16 acres.

The F- and H-Area Seepage Basins were constructed and began operations in 1955. The F-Area Seepage Basins consisted of three unlined basins that were hydraulically connected by vitrified clay process sewers. The seepage basins received process waste water from the F-Area Separations Facilities for a period of 33 years. The major sources of waste were cooling water from tritium facilities, nitric acid recovery overheads, general purpose evaporator overheads, and retention basin transfers (Killian et al., 1987a).Discharges to the basins ceased in November 1988, and closure caps were placed over the basins to minimize infiltration through the basin sediments in 1990 .

The H-Area Seepage Basins also consisted of three unlined basins that were constructed in 1955. In 1962, however, one basin was made inactive and replaced by a fourth basin. The basins received process waste water from the H-Area Separations Facilities until 1988. The main sources of waste water included those listed for the F-Area Seepage Basins, overheads from the two H-Area Tank Farm evaporators, and liquids from the Receiving Basin for Offsite Fuels Facility (Killian et al., 1987b). Discharges to the basins terminated in November 1988. Closure caps were placed over the seepage basins in 1991 to minimize infiltration through the basin sediments.

\subsection{Description of the Environment}

The F-and H-Area occupies approximately 194 acres on a nearly flat divide between Upper Three Runs Creek to the north and Fourmile Branch to the south. Ground surface elevations range from approximately 270 feet above mean sea level (MSL) to approximately 300 feet above MSL. The surface topography generally slopes to the south. Engineered ditches send surface runoff to Fourmile Branch. The bed of Upper Three Runs Creek is about 140 feet below the divide surface; the channel of Fourmile Branch is about 90 feet below the divide surface. A mixture of brushland, sparse forest, and grassland occupies areas to the east, north, and west of the F/H Area. The environment in the vicinity of the FHSB provides habitat for a diverse flora and fauna. Immediately downslope from the basins is old field herbaceous/scrub brush habitat which transitions into upland forest. The upland forest integrades into lowland forest vegetation at the seepline where the groundwater surfaces and flows into the wetlands. The wetland habitat also includes the Fourmile Branch stream community.

Fourmile Branch, a second order blackwater stream, forms the southern boundary of the FHSB environment. From 1955 through 1985, it received cooling water discharge from $C$ Reactor which modified and reduced the original bottomland forest. The waters of Fourmile Branch at SRS Road A-7 (downstream of the point at which constituents from the F- and H-Areas discharge, yet upstream of thermal effluents from C-Reactor) have low alkalinity, suspended solids, and chemical oxygen demand. Concentrations of nutrients in the stream, particularly nitrates (as nitrogen) are generally an order of magnitude higher than in all other SRS streams. These elevated levels of nitrates have been attributed to outcropping of nitrates from shallow groundwater south of the F- and H-Area Seepage Basins. 


\subsection{Baseline Environment Overview}

Baseline refers to existing conditions in the absence of any remedial action. Environmental studies in the vicinity of the FHSB have included sampling and analyses of the abiotic and biotic media. These investigations, which began in the 1950's and continue to date, were summarized by Rogers and Associates (RAEC 1995) in the Five Year Ecological Monitoring Plan. To comprehensively and thoroughly characterize the environment, data should be relatively recent and include both abiotic and biotic components. This section characterizes the baseline environment using existing information and emphasizes data collected since 1990.

\subsection{Abiotic Investigations}

Abiotic investigations include studies of the physical, non-living environment. Numerous samples of soil, sediment, groundwater, surface water, and air have been collected and analyzed at the SRS. With the exception of air and groundwater, the following sections summarize the more recent investigations near F- and HAreas.

\subsubsection{Soil}

Surface and subsurface soil have been sampled and analyzed as part of several independent studies within the Fourmile Branch watershed. Rogers (1990) classified and mapped the soils of the SRS including the FHSB area. Haselow et al. (1990) collected soil cores along the Fourmile Branch seepline bordering the F- and $\mathrm{H}$ Areas in 1988 and 1989. These were analyzed for metals, inorganics, and radionuclides. The concentrations of all inorganics and most metals were below the maximum background concentration (RAEC 1995). Haselow et al. (1990) concluded that Am-241, Cm-241, Co-60, I-129, Ra-226, and Pu-238 may exceed background concentrations (RAEC 1995).

In spring 1990, soil from the Fourmile Branch corridor was analyzed for gamma-emitting radionuclides as part of the SRS monitoring program (WSRC 1991a). Additional samples were subsequently taken in support of the F-Area and H-Area Retention Basin work plans (RAEC 1995). Soil samples in the vicinity of F- and $\mathrm{H}$-Areas were also collected under the radiological monitoring program at the SRS and analyzed for gammaemitting radioisotopes such as cesium, plutonium, and strontium. In 1994, the highest concentration of Cs137 detected on-site ( $n=24$ locations) was $1.01 \mathrm{pCi} / \mathrm{g}$ from a sample taken near H-Area (WSRC 1995a). Pu238 was detected at single locations at F-Area and at the Burial Ground (WSRC 1995a). Strontium in soil exceeded the lower limit of detection at a single location in 1994.

In March 1994, Dixon (1994) collected four surficial soil samples from the wetlands at the old F-Area effluent ditch. Samples were analyzed for metals, volatile organic compounds, and gross radiological indicators. Barium, beryllium, and zinc were detected in each sample whereas antimony was detected in three samples. Concentrations of barium and beryllium were within expected ranges. Concentrations of zinc and antimony; however, were elevated. Five volatile organic compounds were detected. Tritium, the only radionuclide that was detected in significant quantities, was present in all four samples.

In 1995, soil samples were collected from 18 locations including $F$ - and H-Areas and two reference sites 100 miles from SRS (WSRC 1996). Samples were analyzed for gamma-emitting radioisotopes, Sr-89, Sr-90, Pu238, and Pu-239. The highest concentration of Cs-137 detected on the SRS was $1.01 \mathrm{pCi} / \mathrm{g}$ near H-Area (Table 1). This equaled the maximum concentration detected in 1994 (WSRC 1995a). Concentrations of Cs-137 in 1995 ranged from $0.25 \mathrm{pCi} / \mathrm{g}$ to $0.42 \mathrm{pCi} / \mathrm{g}$ at the site perimeter, and from $0.29 \mathrm{pCi} / \mathrm{g}$ to $0.35 \mathrm{pCi} / \mathrm{g}$ at the 100 mile radius locations (WSRC 1996). Radioactivity of cesium, strontium, and plutonium in soil at a depth of 0-8 cm for F-Area, H-Area, and two control sites in 1995 are shown in Table 1. 
TABLE 1. Radioactivity (pCi/g dry wt) in surficial soil (0-8 $\mathrm{cm}$ depth) at F- and H-Areas, 1995 (WSRC 1996).

\begin{tabular}{lcccc}
\hline \hline Location & Sr-89,90 & Cs-137 & Pu-238 & Pu-239 \\
\hline F-Area & & & & - \\
2000 feet east & $3.43 \mathrm{E}-02$ & $9.74 \mathrm{E}-01$ & $6.76 \mathrm{E}-02$ & $6.16 \mathrm{E}-01$ \\
2000 feet north & $0.26 \mathrm{E}-02$ & $1.14 \mathrm{E}-01$ & $4.23 \mathrm{E}-02$ & $1.04 \mathrm{E}-01$ \\
2000 feet south & $0.67 \mathrm{E}-02$ & $1.56 \mathrm{E}-01$ & $8.81 \mathrm{E}-03$ & $1.26 \mathrm{E}-02$ \\
2000 feet west & $0.68 \mathrm{E}-02$ & $6.83 \mathrm{E}-01$ & $6.64 \mathrm{E}-02$ & $8.83 \mathrm{E}-02$ \\
H-Area & & & & \\
2000 feet east & $1.31 \mathrm{E}-02$ & $4.6 \mathrm{E}-01$ & $6.31 \mathrm{E}-03$ & $1.77 \mathrm{E}-02$ \\
2000 feet north & $0.70 \mathrm{E}-02$ & $1.01 \mathrm{E}+00$ & $2.86 \mathrm{E}-02$ & $9.23 \mathrm{E}-02$ \\
2000 feet south & $2.35 \mathrm{E}-02$ & $7.8 \mathrm{E}-01$ & $8.14 \mathrm{E}-03$ & $4.33 \mathrm{E}-02$ \\
2000 feet west & $2.9 \mathrm{E}-02$ & $2.96 \mathrm{E}-01$ & $6.8 \mathrm{E}-03$ & $3.31 \mathrm{E}-02$ \\
100-Mile Radius & & & & \\
Clinton, SC & $7.41 \mathrm{E}-02$ & $2.92 \mathrm{E}-01$ & $5.78 \mathrm{E}-04$ & $6.81 \mathrm{E}-03$ \\
Savannah, GA & $1.94 \mathrm{E}-02$ & $3.55 \mathrm{E}-01$ & $4.18 \mathrm{E}-04$ & $6.29 \mathrm{E}-03$ \\
\hline
\end{tabular}

\subsubsection{Sediment}

Sediment is the fine, inundated material that lies at the bottom of impoundments, streams, and rivers. It occurs at both seeplines where shallow pools and saturated conditions exist and also in Fourmile Branch. Radionuclides and certain chemicals typically concentrate in the uppermost strata of sediment, posing potential exposure to invertebrates, other aquatic organisms, and vertebrates such as fish which occupy higher trophic levels.

Sediment in Fourmile Branch was collected in 1987 at five locations and analyzed for metals, organics, pesticides, and polychlorinated biphenyls (E.I. du Pont 1988). These locations and three additional samples were also analyzed for radionuclides. In 1989, Haselow (1990) sampled streambed sediments at six locations in Fourmile Branch to support the preparation of the Part B Postclosure Care Permit for the F- and H-Area Seepage Basins. This study showed that downstream sampling locations had higher concentrations than upstream locations because of particulate transport by Fourmile Branch. Comparisons of sediment concentrations to background soils showed that cadmium and copper exceeded maximum background values.

Sediment from the streambed of Fourmile Branch was collected from three locations in 1994 (WSRC 1995a). Of the 22 sampling locations that were used in the SRS environmental monitoring program, Fourmile Branch had the highest concentration of $\mathrm{Pu}-238, \mathrm{Pu}-239, \mathrm{Sr}-89$, and $\mathrm{Sr}-90$. Co-60 was also detected in sediment from Fourmile Branch.

In 1995, the maximum strontium-89,90 concentration measured at SRS was in Fourmile Branch (WSRC 1996). This level, however, was lower than the concentration found in 1994. Between May and September 1995, RUST Environment \& and Infrastructure collected sediment samples (Figure 2) from the F-and H-Area seeplines, Fourmile Branch, and background locations (WSRC 1995b). Coordinates for the sediment sampling locations are given in Appendix A, Table A-1. Samples were analyzed by General Engineering Laboratories and data validation was performed by BAT Associates, Inc. (WSRC 1995b). The mean and upper 95\% confidence intervals for non-radiological and radiological constituents in sediment collected in 1995 from these four areas are presented in Appendix B, Tables B-1 and B-2, respectively. 


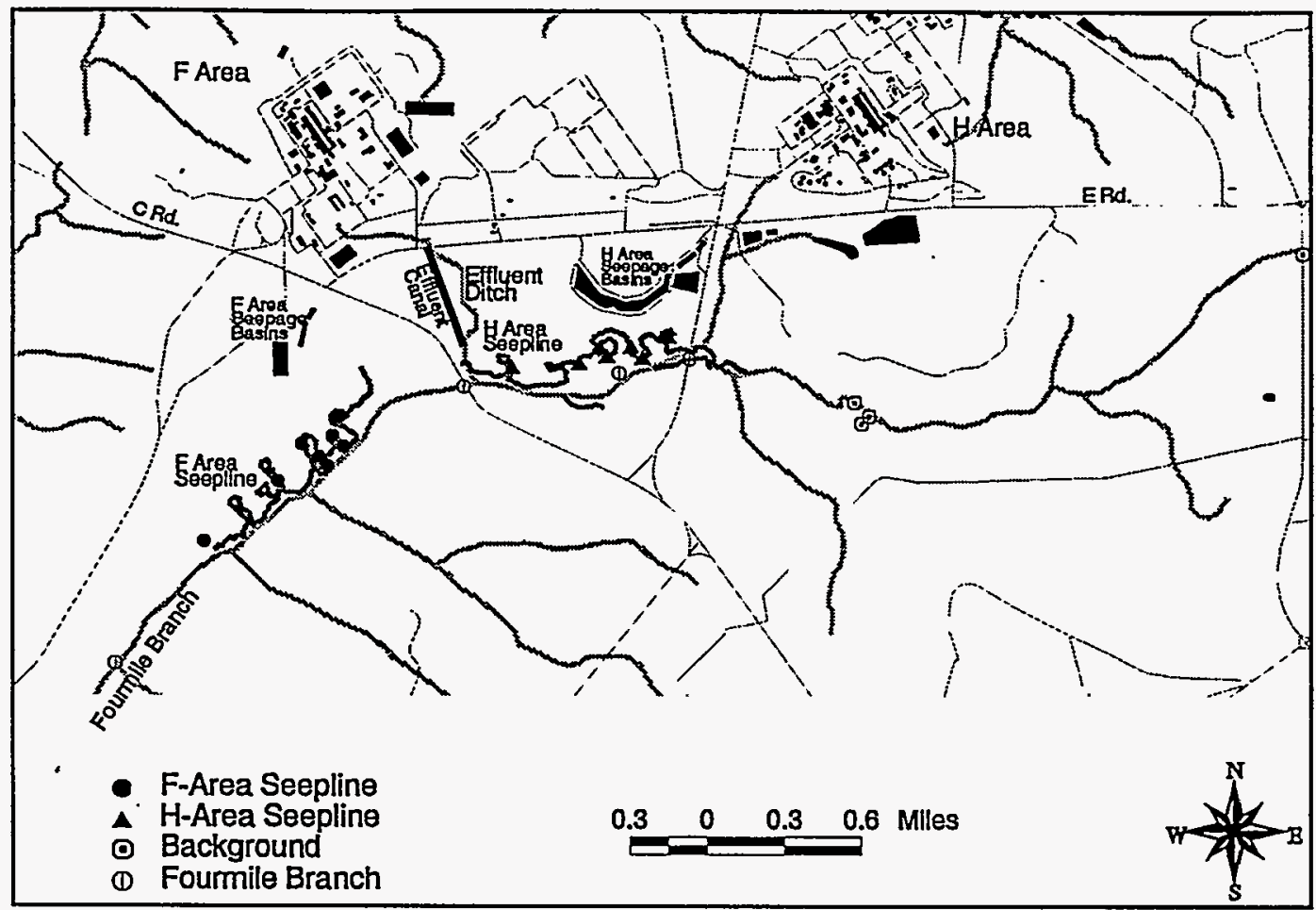

FIGURE 2. Distribution of sediment and surface water sampling locations, 1995 (WSRC 1995b).

The majority of non-radiological constituents in sediment collected in 1995 had $95 \%$ upper confidence intervals that exceeded background concentrations (Table 2). When compared to EPA Region IV ecological sediment screening values (EPA 1995), Fourmile Branch had seven constituents whose $95 \%$ upper confidence intervals exceeded EPA threshold values. The F-Area seepline had three constituents (arsenic, cadmium, and silver) that exceeded threshold values whereas the $\mathrm{H}$-Area seepline had two (arsenic and copper). Arsenic was the only constituent that exceeded the sediment screening level at all three areas. The concentration of copper, nickel, and zinc did not exceed ecological screening values at the seeplines but did so in Fourmile Branch.

Although radiological sediment screening values for human health and ecology have not been issued by EPA, activity levels for 44 radioisotopes, gross alpha, and non-volatile beta were reported for 1995 (Table B-2). Of these, tritium contributed the highest radioactivity of the constituents measured in sediment. The mean radioactivity of tritium ranged from $-0.45 \mathrm{pCi} / \mathrm{g}$ at background locations to $289 \mathrm{pCi} / \mathrm{g}$ at Fourmile Branch. Other radioisotopes having activity levels higher than $10 \mathrm{pCi} / \mathrm{g}$ in 1995 included Tc-99, Cs-137, Ni-63, Sr-90. 
TABLE 2. List of constituents in sediment that exceeded background and ecological (EPA 1995) screening values, 1995.

\begin{tabular}{|c|c|c|c|c|c|c|}
\hline \multirow[t]{2}{*}{ Constituent } & \multicolumn{3}{|c|}{ 95\% UCI Exceeded Background } & \multicolumn{3}{|c|}{ 95\% UCI Exceeded Ecological } \\
\hline & $\begin{array}{l}\text { F-Area } \\
\text { Seepline }\end{array}$ & $\begin{array}{l}\text { H-Area } \\
\text { Seepline }\end{array}$ & $\begin{array}{c}\text { Fourmile } \\
\text { Branch }\end{array}$ & $\begin{array}{l}\text { F-Area } \\
\text { Seepline }\end{array}$ & $\begin{array}{c}\text { H-Area } \\
\text { Seepline }\end{array}$ & $\begin{array}{c}\text { Fourmile } \\
\text { Branch }\end{array}$ \\
\hline Aluminum & $\because \because \bullet$ & $\therefore$ & $6: \div$ & 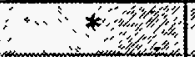 & $\therefore *$ & *. \\
\hline Ammonia as $\mathrm{N}$ & $\bullet$ & $\bullet$ & $\bullet$ & * & * & * \\
\hline Antimony & $\cdot$ & $\therefore$ & $4:-3$ & $\therefore \quad$, & sin & \\
\hline Arsenic & & $\bullet$ & $\bullet$ & $\bullet$ & $\bullet$ & $\bullet$ \\
\hline Barium & $\bullet$ & $\because$ & $\because$ & $*$ & $*$ & $*$ \\
\hline Beryllium & $\bullet$ & $\bullet$ & $\bullet$ & $*$ & $*$ & * \\
\hline Cadmium & $?$ & $\because$ & $\therefore$ & $\begin{array}{l}-\infty \\
-3\end{array}$ & & $\bullet$ \\
\hline Calcium & $\bullet$ & $\bullet$ & $\bullet$ & * & $*$ & * \\
\hline Chloride & in & $\because$ & 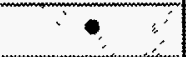 & $*$ & * & * \\
\hline Chromium & & & $\bullet$ & & & \\
\hline Cobalt & $\bullet$ & 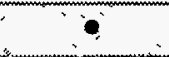 & $\dot{\varphi}$ & * & $*$ & $*$ \\
\hline Copper & $\bullet$ & $\bullet$ & $\bullet$ & & & - \\
\hline Cyanide & $\therefore \cdots$ & 1" & 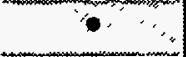 & 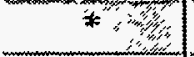 & $\because *$ & $*$ \\
\hline Iron & & & $\bullet$ & * & * & * \\
\hline Lead: & 4 & 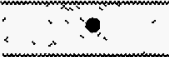 & $\because \ldots$ & $y^{\prime} \vee:$ & $\therefore$ & \\
\hline Magnesium & $\bullet$ & $\bullet$ & $\bullet$ & * & $*$ & * \\
\hline Manganese & $\because 2$ & - & 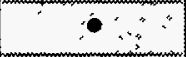 & 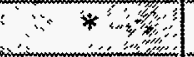 & $*$ & * \\
\hline Mercury & & $\bullet$ & $\bullet$ & & $\bullet$ & $\bullet$ \\
\hline Nickel & 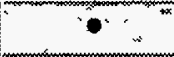 & $\div$ & 6 & 3 & $\because$ & - \\
\hline Nitrate & $\bullet$ & $\bullet$ & $\bullet$ & $*$ & $*$ & * \\
\hline Nitrate/Nitrite & 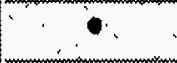 & 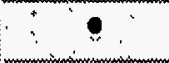 & $\bullet$ & * & 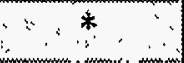 & $*$ \\
\hline Potassium & $\bullet$ & $\bullet$ & $\bullet$ & $*$ & $*$ & $*$ \\
\hline Selenium & $x y=$ & 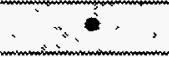 & $\bullet$ & 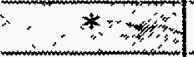 & $\therefore *$ & $*$ \\
\hline Silver & $\bullet$ & $\bullet$ & $\bullet$ & $\bullet$ & & $\bullet$ \\
\hline Sodium & $\because$ & $\div$ & $\because$ & * & 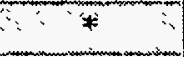 & $*$ \\
\hline Thallium & $\bullet$ & $\bullet$ & $\bullet$ & * & * & * \\
\hline Tin $\cdots$ & $\%$ & $\because \because$ & $\because \vdots$ & 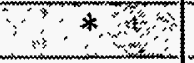 & * : & $\therefore * *$ \\
\hline Vanadium & & & $\bullet$ & $*$ & $*$ & $*$ \\
\hline Zíne & $\because$ & $\because$ & $\because$ & & $\because \because$ & $\bullet$ \\
\hline
\end{tabular}

* - EPA has not issued a screening value for this constituent. 


\subsubsection{Surface Water}

Surface water in the vicinity of the FHSB consists primarily of the waters of Fourmile Branch and shallow pools associated with the seeplines. Fourmile Branch (Figure 3) originates near the center of SRS and flows southwesterly for approximately $24 \mathrm{~km}$ (Wike et al. 1994). The Fourmile Branch watershed covers approximately $57 \mathrm{~km}^{2}$ and drains several facilities including C-Area, F-and $\mathrm{H}$-Areas, and the Solid Waste Disposal Facility. The headwaters of Fourmile Branch is a small blackwater stream that has been relatively unimpacted by SRS operations (Specht 1987). In its lower reaches, Fourmile Branch broadens and flows through a delta that was formed by the deposition of sediments. Downstream of the delta Fourmile Branch becomes one main channel that flows primarily into the Savannah River. Some water, however, flows west and enters Beaver Dam Creek. When the Savannah River floods, water from Fourmile Branch flows along the northern boundary of the floodplain swamp and joins with Steel Creek and Pen Branch instead of flowing directly into the Savannah River (Specht 1987).

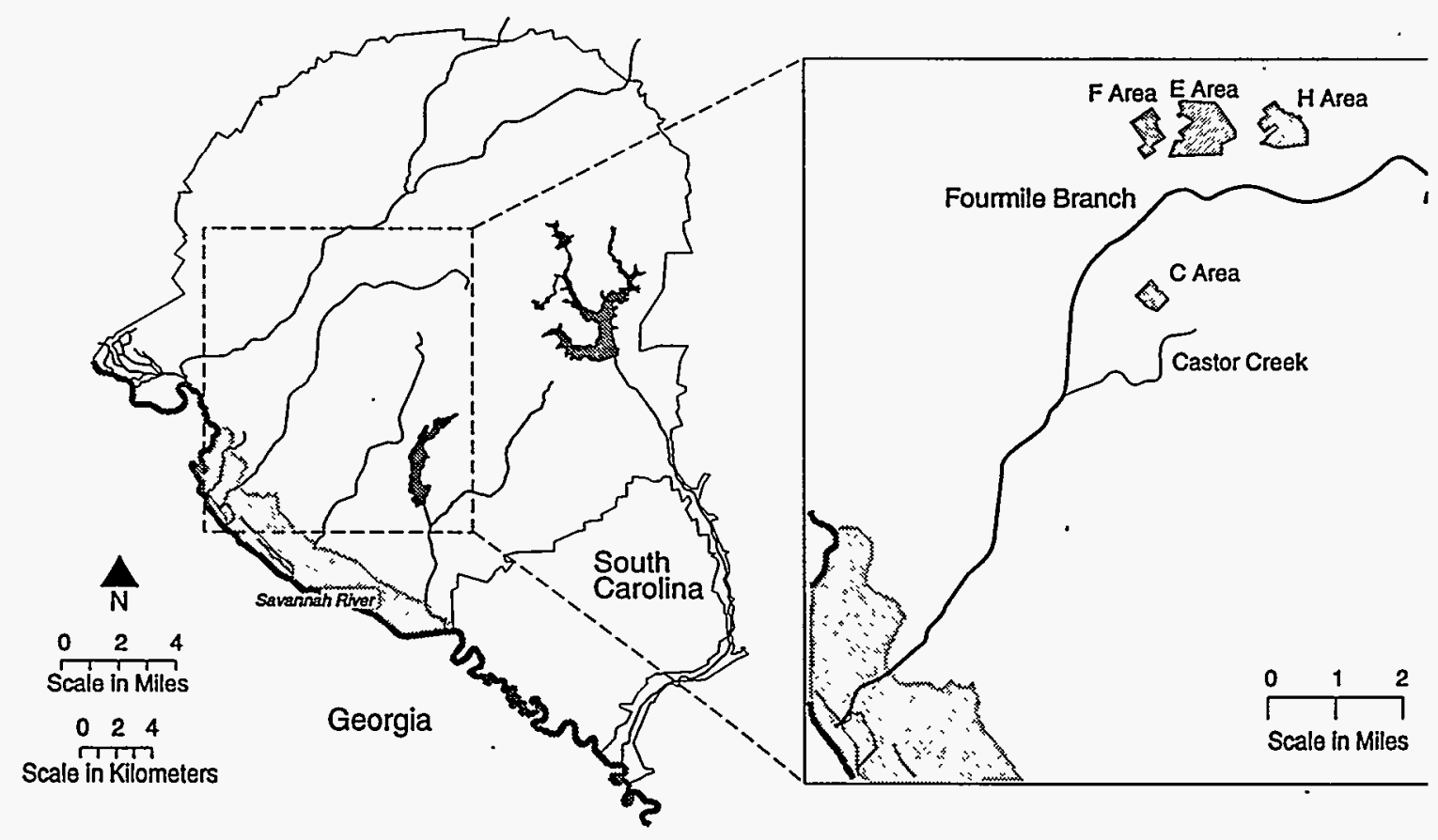

FIGURE 3. The Savannah River Site showing the location of Fourmile Branch.

\subsubsection{Flow Measurements}

The U. S. Geological Survey measured SRS stream flow at two locations on Fourmile Branch (Figure 4). Records for the most downstream station (Fourmile Branch at Road A-12.2) date back to November 1976. In water year 1991, the mean flow of Fourmile Branch at Road A-12.2 was $1.8 \mathrm{~m}^{3} / \mathrm{s}\left(63.1 \mathrm{ft}^{3} / \mathrm{s}\right)$. Over the period of record (water years 1977-1991) at Road A-12.2, the mean flow was $5.9 \mathrm{~m}^{3} / \mathrm{s}\left(208 \mathrm{ft}^{3} / \mathrm{s}\right)$, the 7-day low flow was $0.22 \mathrm{~m}^{3} / \mathrm{s}\left(7.6 \mathrm{ft}^{3} / \mathrm{s}\right)$, and the $7 \mathrm{Q} 10$ was $0.31 \mathrm{~m}^{3} / \mathrm{s}\left(11.1 \mathrm{ft}^{3} / \mathrm{s}\right)$. The maximum, minimum, and mean daily flows for the periods of record at both locations are shown in Figures 5 and 6. 


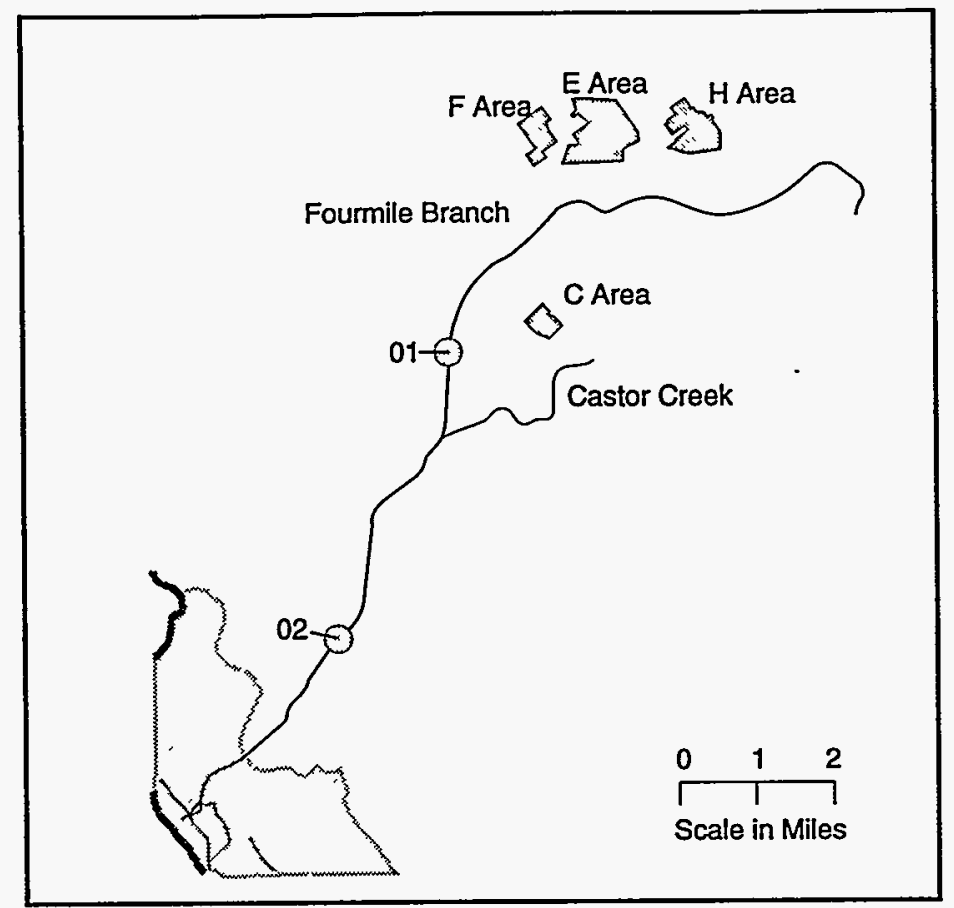

FIGURE 4. Flow Measurement Stations 01 and 02, Fourmile Branch (Wike et al. 1994).

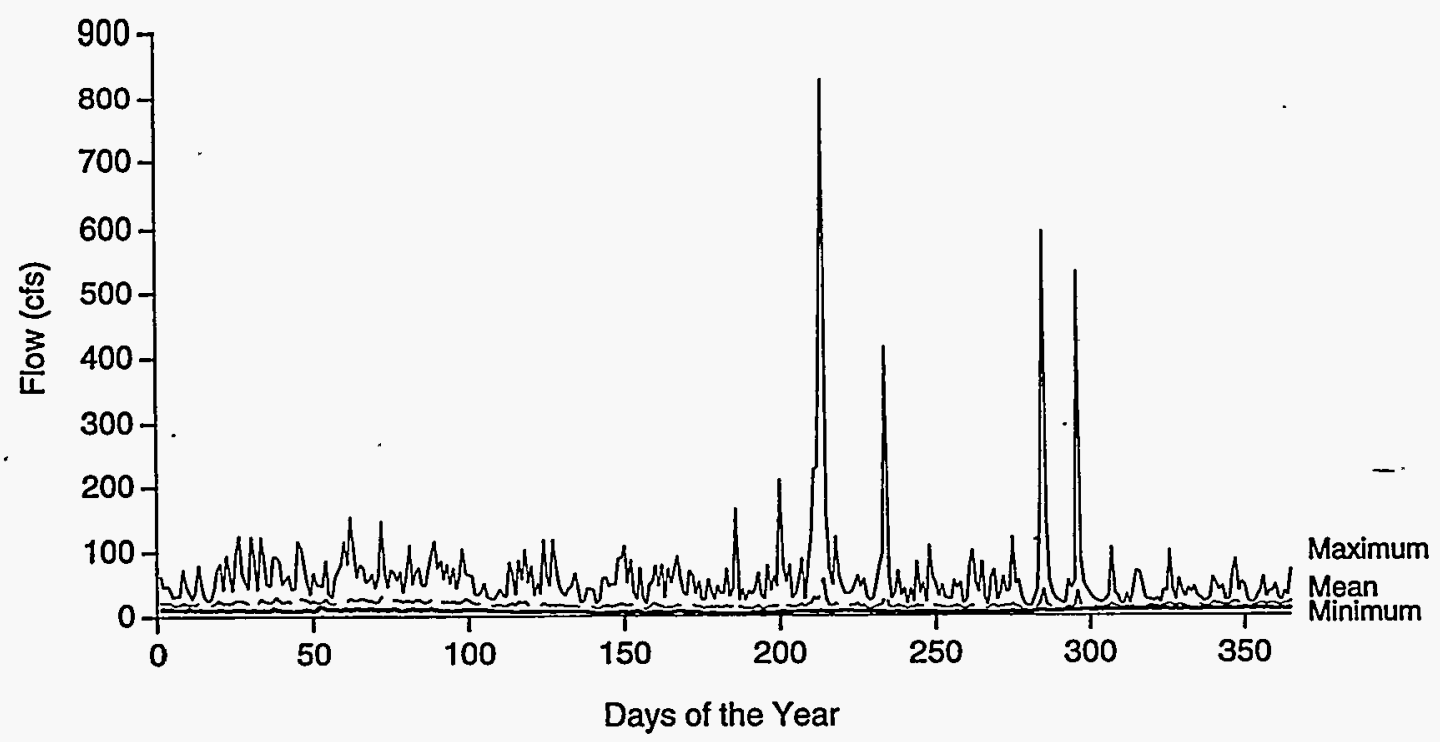

FIGURE 5. Maximum, mean, and minimum flow measurements at Station 01 (Wike et al. 1994). 


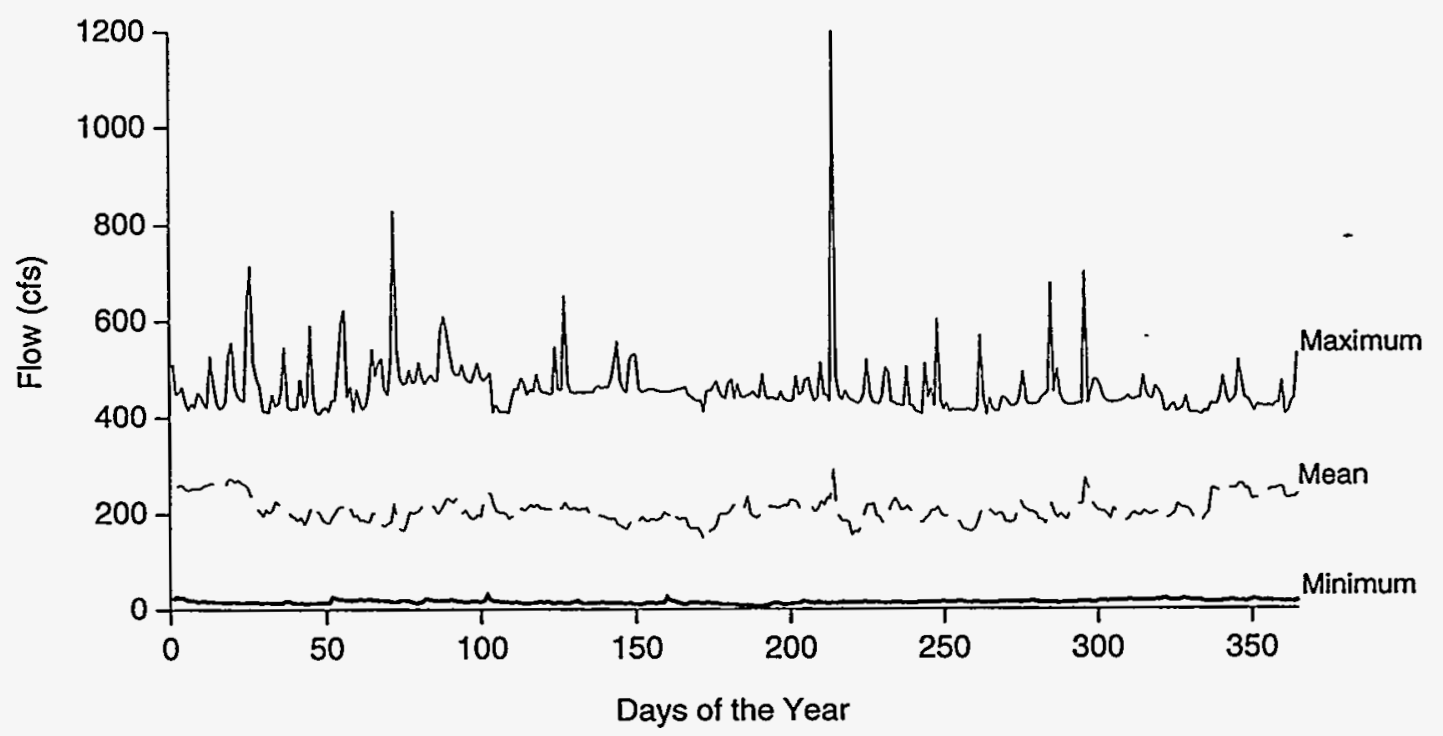

FIGURE 6. Maximum, mean, and minimum flow measurements at Station 02 (Wike et al. 1994).

\subsubsection{Surface Water Chemistry}

Numerous studies have examined surface water chemistry of the F-and H-Area seeplines and Fourmile Branch. These investigations have ranged from routine monitoring of radionuclides and chemicals to special studies designed to more fully characterize specific areas. In the late 1980's, several investigators examined surface water chemistry in the vicinity of the FHSB (Looney 1988, Haselow et al. 1990). In the 1990's, three programs were implemented in the vicinity of F-and H-Areas: (1) semi-annual sampling of the F-and H-Area Seeplines and Fourmile Branch, (2) quarterly tritium surveys of the F-and H-Area seeplines, and (3) quarterly sampling of wetland surface waters along the old F-Area effluent ditch. These programs are summarized below.

\section{Semi-Annual Sampling Program (1992-1990)}

A semi-annual sampling program was initiated in 1992 to examine the presence and concentration of contaminants associated with the seepage basins in surface water at the F-and H-Area seeplines and Fourmile Branch. Beginning in 1994, however, sampling was done annually through 1996. Surface water investigations that were conducted during this period are described below. Sampling locations (Figure 7) were relatively consistent each year, but sometimes varied depending on environmental conditions (Table 3 ).

In July 1992, Dixon and Rogers (1993) began examining surface water from the F-and H-Area seeplines and Fourmile Branch as the first of three semi-annual sampling events designed to characterize the surface water in the vicinity of the FHSB. Samples were collected in July 1992 by Normandeau Associates, Inc. under a subcontract to Metcalf and Eddy, Inc. The samples were analyzed for RCRA Appendix IX metals, radionuclides, volatile compounds, and inorganic constituents and physical parameters. Concentrations of constituents were compared to primary drinking water standards (PDWS), secondary drinking water standards (SDWS), and maximum contaminant levels (MCLs). Statistical comparisons to background concentrations were also performed. In order to evaluate trending, comparisons were also made with the 1989 results reported by Haselow et al., 1990. Results indicated that most of the non-radiological constituents, particularly sodium and aluminum, had declined at the seeplines and in Fourmile Branch. The concentrations of some radionuclides were unchanged from levels reported earlier. 


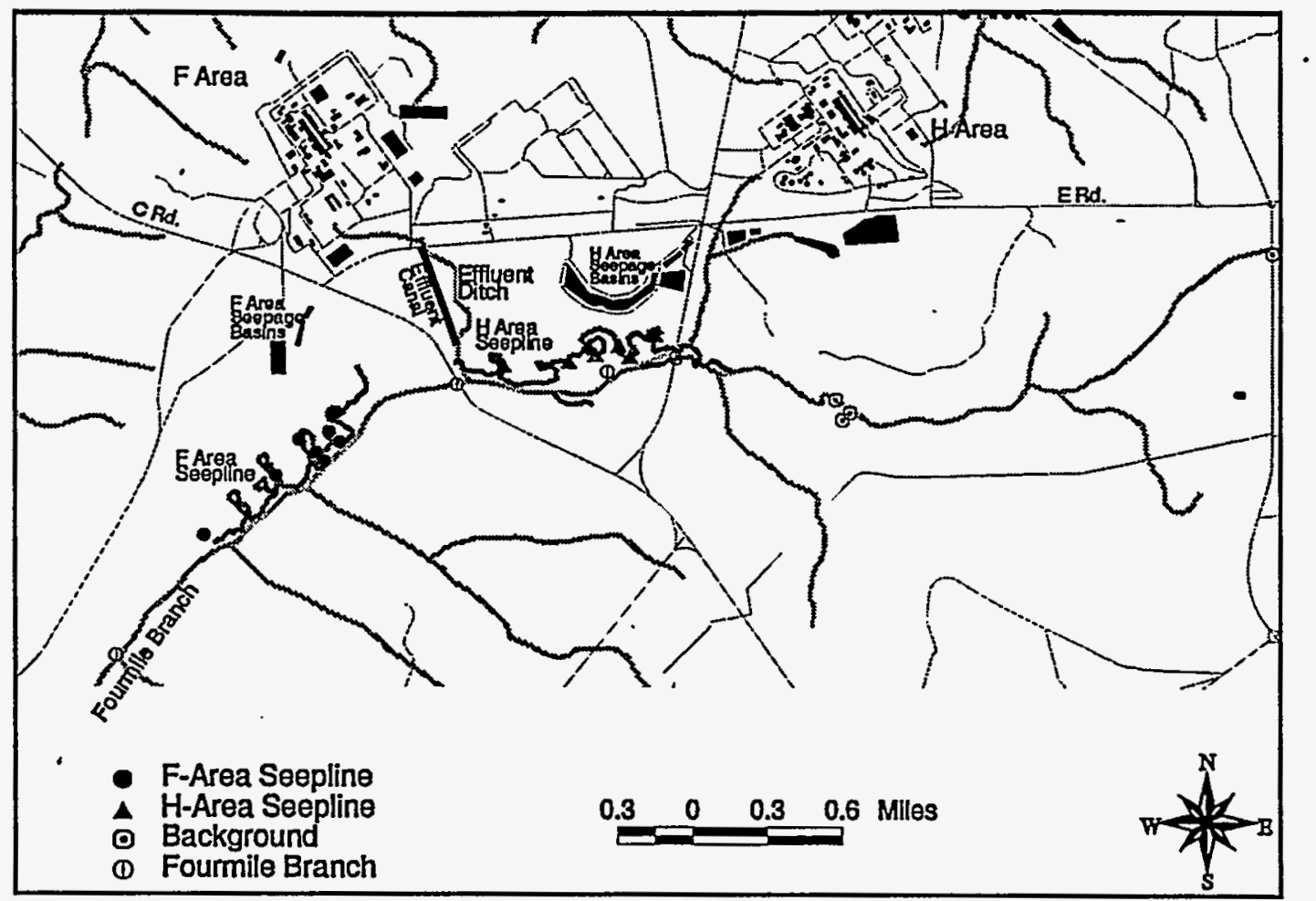

FIGURE 7: Distribution of surface water sampling locations, 1989-1996.

The semi-annual sampling program continued in 1993 (Chappell et al. 1996). Normandeau Associates, Inc. collected samplès between 25 January and 4 February 1993; and also between 19-22 July 1993 (Metcalf and Eddy 1993 a,b). In 1994, semi-annual sampling was discontinued, and a single sampling effort was conducted between 11-21 April (Metcalf and Eddy 1994). Samples collected in 1993 and 1994 were analyzed for Appendix IX metals, radionuclides, selected volatile organic compounds, and inorganic constituents and parameters. Chappel et al. (1995) reported that the F-and H-Area seeplines and Fourmile Branch continued to be influenced by contaminants migrating from the F-and H-Area seepage basins. Concentrations of many constituents, however, had declined from 1989 levels reported by Haselow et al. (1990).

In 1995, RUST Environment \& Infrastructure, under subcontract to the Environmental Monitoring-Section of WSRC, collected surface water samples (Figure 2) near the F-and H-Area seeplines (WSRC 1995b). This sampling event was in addition to that done under the semi-annual sampling program. Laboratory analyses and data validation were performed by General Engineering Laboratories and BAT Associates, Inc., respectively (WSRC 1995b). Samples were analyzed for metals, radionuclides, inorganic constituents, and other parameters (Appendix B, Tables B3 and B4). Table 4 compares $95 \%$ upper confidence intervals for nonradiological constituents in surface water with background, ecological, and human health benchmarks. Ecological benchmarks were chronic ambient water quality criteria issued by EPA Region IV (EPA 1995). Human health benchmarks included risk-based concentrations (EPA 1997), maximum contaminants levels (MCLs), primary drinking water standards (PDWS), and secondary drinking water standards (SDWS). Based on the results of the 1995 data, 17 non-radiological constituents had concentrations that exceeded ecological and human health benchmarks (Table 4). Radiological constituents in surface water that exceeded PDWS, MCLs, and SDWS standards in 1995 were Am-241, Cs-134, Cs-137, Co-57, Co-60, Eu-154, I-129, Na-22, Np-237, Ra-226, Ra-228, Ru-106, Sb-125, Sr-90, Th-228, Th-230, Th-232, tritium, U-235, and U-238 (Table $\mathrm{B}-4)$. 
TABLE 3. Semi-annual sampling locations for surface water, 1989-1996.

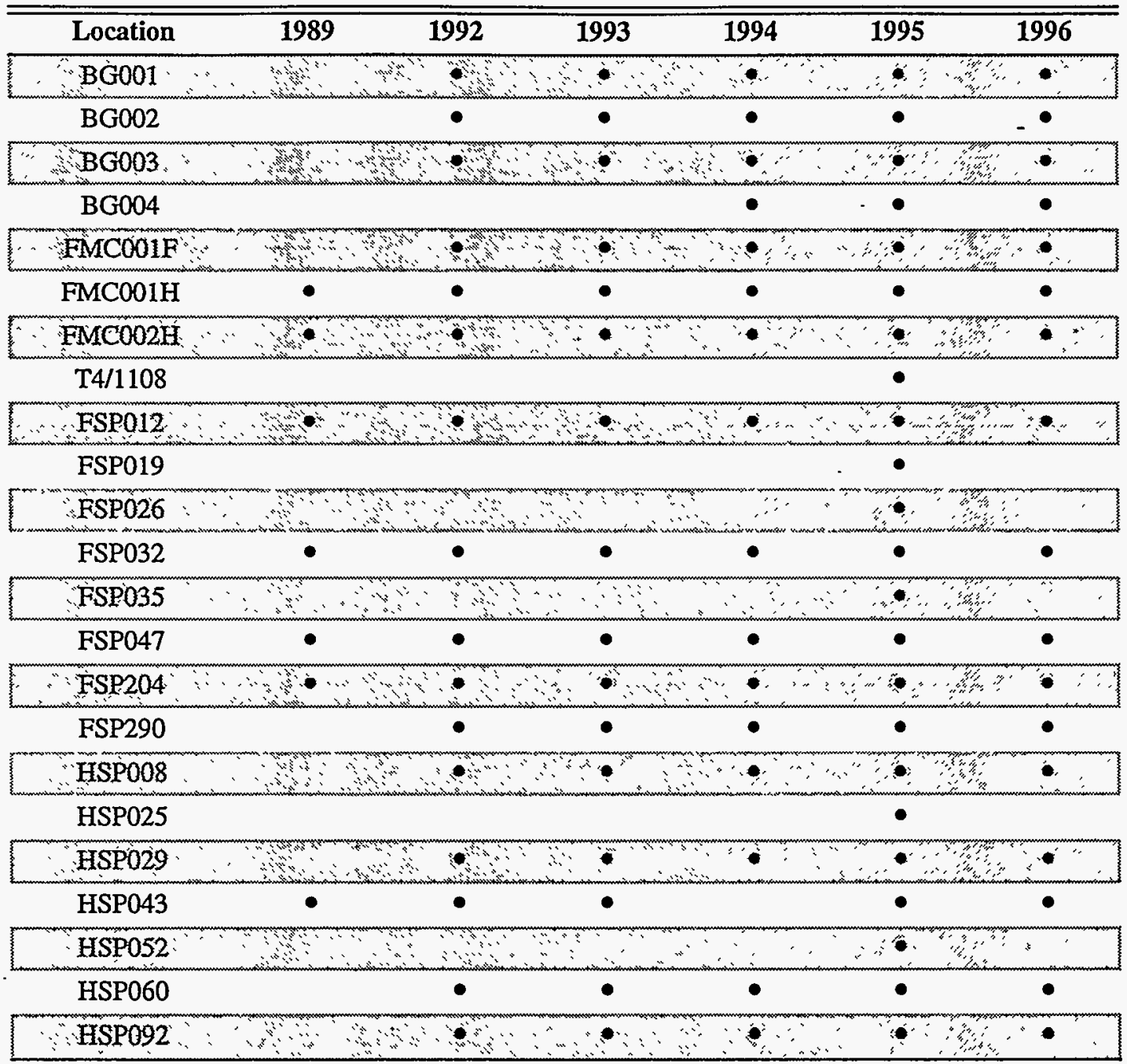

In April 1996, organic and inorganic analyses were discontinued because none of the constituents exceeded primary drinking water standards (PDWS), secondary drinking water standards (SDWS), or maximum contaminant levels (MCLs). The analytical results for the 1996 sampling and analyses program have not been completed. Preliminary results for non-radiological and radiological constituents are presented in Appendix $\mathrm{B}$, Tables B-5 and B-6.

\section{Old F-Area Ditch}

The old F-Area ditch is a natural drainage pathway that historically received discharges and surface runoff from F-and H-Areas. In 1994, a quarterly sampling program was initiated to examine tritium and volatile organic compounds (VOCs) in water collected from a series of shallow wells located along the old F-Area effluent ditch (Figure 1). In 1995, sampling was reduced to a single event in September. Sampling was also conducted in March and October, 1996. A summary of these investigations is given below.

In March 1994, Dixon et al. (1994a) collected samples from seven locations in the wetlands along the old FArea effluent ditch and also at two background locations in the vicinity of Upper Three Runs Creek. Both shallow wells and buckets were used. Results indicated that tritium and volatile organic compounds, presumably originating from the old burial ground $(643-\mathrm{E})$, had reached the wetlands. These findings are consistent 
TABLE 4. Constituents in surface water whose 95\% UCI exceeded background, ecological, and human health benchmarks at Fourmile Branch (FMB) and the F-and H-Area seeplines, 1995.

\begin{tabular}{|c|c|c|c|c|c|c|c|}
\hline \multirow[t]{2}{*}{ Constituent } & Exceeded Bàckground & \multicolumn{3}{|c|}{ Exceeded Human Health } & \multicolumn{3}{|c|}{ Exceeded Ecological } \\
\hline & FMB FSP HSP & FMB & FSP & HSP & FMB & FSP & HSP \\
\hline Aluminum & 6 & $\bullet$ & $\bullet$ & $\bullet$ & $\bullet$ & $\bullet$ & $\bullet$ \\
\hline Ammonia as $N$ & & $\bullet$ & & . & $\cdot *$ & $\star$ & * \\
\hline Antimony & & & & - & . & $\therefore$ & \\
\hline Arsenic & $\div$ & & & & & & \\
\hline Barium & & & & & * & * & * \\
\hline Beryllium & & $\bullet$ & - & - & & $\bullet$ & $\bullet$ \\
\hline Cadmium & & $\bullet$ & $\bullet$ & & $\bullet$ & $\bullet$ & $\bullet$ \\
\hline Calcium & & * & * & * & * & * & * \\
\hline Chloride & & & & & & & 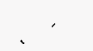 \\
\hline Chromium & 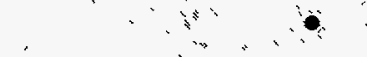 & & & & v & $\bullet$ & $\bullet$ \\
\hline Cobalt & & & & & * & * & * \\
\hline Copper & 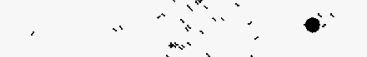 & & & & & $\bullet$ & - \\
\hline Cyanide & & & & & $\bullet$ & $\bullet$ & $\bullet$ \\
\hline Iron & & $\bullet$ & $\bullet$ & $\bullet$ & $\bullet$ & $\bullet$ & - \\
\hline Lead & & & & & - & - & - \\
\hline Magnesium & & * & * & * & * & * & * \\
\hline Manganese & & $\bullet$ & $\bullet$ & $\bullet$ & $\star$ & $\star^{\prime}$ & \\
\hline Mercury & & & & & & - & \\
\hline Nickel & 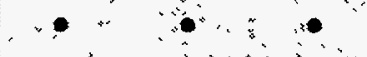 & & & & & $\therefore$ & \\
\hline Nitrate & & $\bullet$ & & & * & * & \\
\hline Nitrate/Nitrite & 1 & * & * & * & * & * & $*$ \\
\hline Potassium & $\because \cdots$ & * & * & * & * & $*$ & $*$ \\
\hline Selenium & & & & & - & ". & 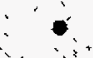 \\
\hline Silver & & & & & $\because$ & $\because$ & $\because$ \\
\hline Sodium & 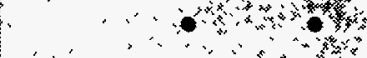 & * & * & * & * & * & * \\
\hline Thallium & & $\bullet$ & $\bullet$ & - & 6 & & \\
\hline Tin & $\therefore$ & & & & $*$ & $*$ & $*$ \\
\hline Vanadium & 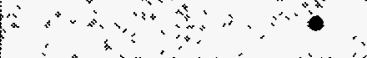 & & & & * & * & $*$ \\
\hline Zinc & 8 & & & & & $\bullet$ & $\because$ \\
\hline
\end{tabular}

* EPA has not issued a screening value for this constituent.

with results from monitoring wells in the vicinity of 643-E. Dixon et al. (1994a) also compared tritium concentrations in shallow wells with buckets and concluded that the sampling devices had intercepted different groundwater flow paths.

Results from sampling in May (Dixon and Cummins 1994), August (Cummins and Dixon 1994), and November (Cummins and Dixon 1995) were consistent with the March 1994 findings with the exception of detecting 
additional constituents. Because the use of both buckets and point wells to collect samples was not providing significantly different information and to maximize cost savings, buckets were discontinued beginning in November 1994. Sampling continued in September 1995, March 1996, and October 1996 (Dixon 1996a, Dunn and Dixon 1996). Although additional constituents were detected, the findings were consistent with previous reports.

Constituents that exceeded PDWS or MCLs at a minimum of one location between March 1994 and November 1996 are listed in Table 5. Concentrations of tetrachloroethylene, trichloroethylene, and tritium exceeded these benchmarks for all of the seven sampling events. Constituents that did not exceed these benchmarks but were detected included acetone, methyl ethyl ketone, chloromethane, toluene, methyl chloride, and trans-1,2dichloroethylene.

TABLE 5. Constituents in surface water along the Old F-Area Effluent Ditch that exceeded Primary Drinking Water Standards or Maximum Contaminant Levels, 1994-1996 (Dixon et al. 1994, Dixon and Cummins 1994, Cummins and Dixon 1994, 1995, Dixon 1996a).

\begin{tabular}{lccc}
\hline \hline Constituent & 1994 & 1995 & 1996 \\
\hline 1,2-Dichloroethylene & $\bullet$ & & \\
cis,-1,2-Dichloroethylene & $\bullet$ & & \\
Tetrachloroethylene & $\bullet$ & $\bullet$ & $\bullet$ \\
Trichloroethylene & $\bullet$ & $\bullet$ & $\bullet$ \\
Tritium & $\bullet$ & $\bullet$ & $\bullet$ \\
Vinyl Chloride & $\bullet$ & $\bullet$ & \\
\hline
\end{tabular}

\section{Tritium Program (1992-1996)}

Looney et al. (1988) collected surface water from the seeplines and Fourmile Branch in 1987 and reported that sodium, nitrate, and hydrogen ions had migrated from the seepage basins to the seeplines. It was also reported that several metals were leaching from the subsurface due to low $\mathrm{pH}$. Concentrations of all constituents were below PDWS standards (Looney et al. 1988). Haselow et al. (1990) also collected surface water along the seeplines and Fourmile Branch in 1989. With the exception of cadmium at the F-Area seepline, concentrations of metals were below the PDWS. However, elevated levels of aluminum and sodium were noted. Six radioisotopes, including tritum, had activity levels at the seeplines that were greater than proposed or established drinking water standards.The concentration of nitrate also exceeded the PDWS at the seeplines. In Fourmile Branch, Haselow et al. (1990) reported that gross beta and tritium exceeded drinking water standards at least one location. Concentrations of nitrate exceeded drinking water standards at both seeplines but not in Fourmile Branch (Haselow et al. 1990).

In May 1992, a quarterly sampling and analysis program was initiated to examine tritium, $\mathrm{pH}$, and specific electrical conductance (i.e., conductivity) in surface waters at the seeplines and in Fourmile Branch. Quarterly sampling continued through 1995. In 1996, semi-annual sampling began. Results of these investigations have been reported by Koch and Dixon (1994, 1995, 1996 a,b), Dixon and Rogers (1992, 1993 a,b, c, d, e; 1994 a,b), Dixon et al. (1993, 1994 a,b) and Rogers et al. (1994 a,b).

\section{Tritium}

The mean radioactivity of tritium at both seeplines and Fourmile Branch has declined annually since 1989 (Table 6). At the F-Area seepline, mean activities ranged from $3357 \mathrm{pCi} / \mathrm{mL}$ in 1989 to $1484 \mathrm{pCi} / \mathrm{mL}$ in 1996 (Figure 8). Based on a Kruskal-Wallis nonparametric analysis of variance, radioactivity at the F-Area seepline was not significantly different $(P>0.05)$ between years. Tritium levels at the H-Area seepline have also declined each year since 1989 (Table 6). At the H-Area seepline, radioactivity of tritium ranged from 
$8402 \mathrm{pCi} / \mathrm{mL}$ in 1989 to $994 \mathrm{pCi} / \mathrm{mL}$ in 1996 (Figure 9). The mean radioactivity of tritium for 1989 was significantly higher $(\mathrm{P}<0.05)$ than levels for 1992 through 1996. Significant differences were also found between 1996 and 1992 and also between 1996 and 1993. Levels of tritium from the 1995 RUST survey (WSRC $1995 \mathrm{~b}$ ) were higher than those reported by the quarterly tritium program. The mean radioactivity for $\mathrm{F}$ - and H-Area seeplines was 4000 and $2100 \mathrm{pCi} / \mathrm{mL}$, respectively (Table B-4). Tritium radioactivity in Fourmile Branch was $958 \mathrm{pCi} / \mathrm{mL}$ in 1995 (WSRC 1995b).

Boxplots of tritium radioactivity at both seeplines and Fourmile Branch from 1989 to 1996 are shown in Figure 10. The top and bottom of the box represent the 75th and 25th percentiles, respectively. Thus, half of the observed values are contained within the box. Median values are represented by horizontal lines approximately mid-way in the box. The largest and smallest observed values that are not outliers are identified by the lines that extend above and below the boxes. Generally, tritium radioactivity is highest at the H-Area seepline, intermediate at the F-Area seepline, and lowest in Fourmile Branch. There has a marked annual decline of tritium radioactivity at each location since 1989 (Figure 10).

TABLE 6. Mean radioactivity (pCi/mL) and $95 \%$ upper confidence intervals (UCD) of tritium at the F-and H-Area Seeplines and Fourmile Branch, 1989-1996.

\begin{tabular}{|c|ccc|ccc|ccc}
\hline \hline \multirow{2}{*}{ Year } & \multicolumn{3}{|c|}{ F-Area Seepline } & \multicolumn{3}{c|}{ H-Area Seepline } & \multicolumn{3}{c|}{ Fourmile Branch } \\
\cline { 2 - 10 } & $\mathbf{N}$ & Mean & $\mathbf{9 5 \%}$ UCI & N & Mean & 95\% UCI & N & Mean & 95\% UCI \\
\hline 1989 & 22 & 3357 & 5326 & 22 & 8402 & 11621 & - & - & - \\
\hline 1992 & 66 & 1916 & 2625 & 66 & 3345 & 4235 & 3 & 853 & 3475 \\
\hline 1993 & 87 & 1892 & 2563 & 87 & 2667 & 3326 & 9 & 219 & 385 \\
\hline 1994 & 87 & 1671 & 2210 & 83 & 2163 & 2941 & 12 & 179 & 289 \\
1995 & 21 & 1634 & 2556 & 18 & 1547 & 2877 & 3 & 268 & 1076 \\
\hline 1996 & 43 & 1484 & 2118 & 39 & 994 & 1404 & 6 & 145 & 342 \\
\hline
\end{tabular}




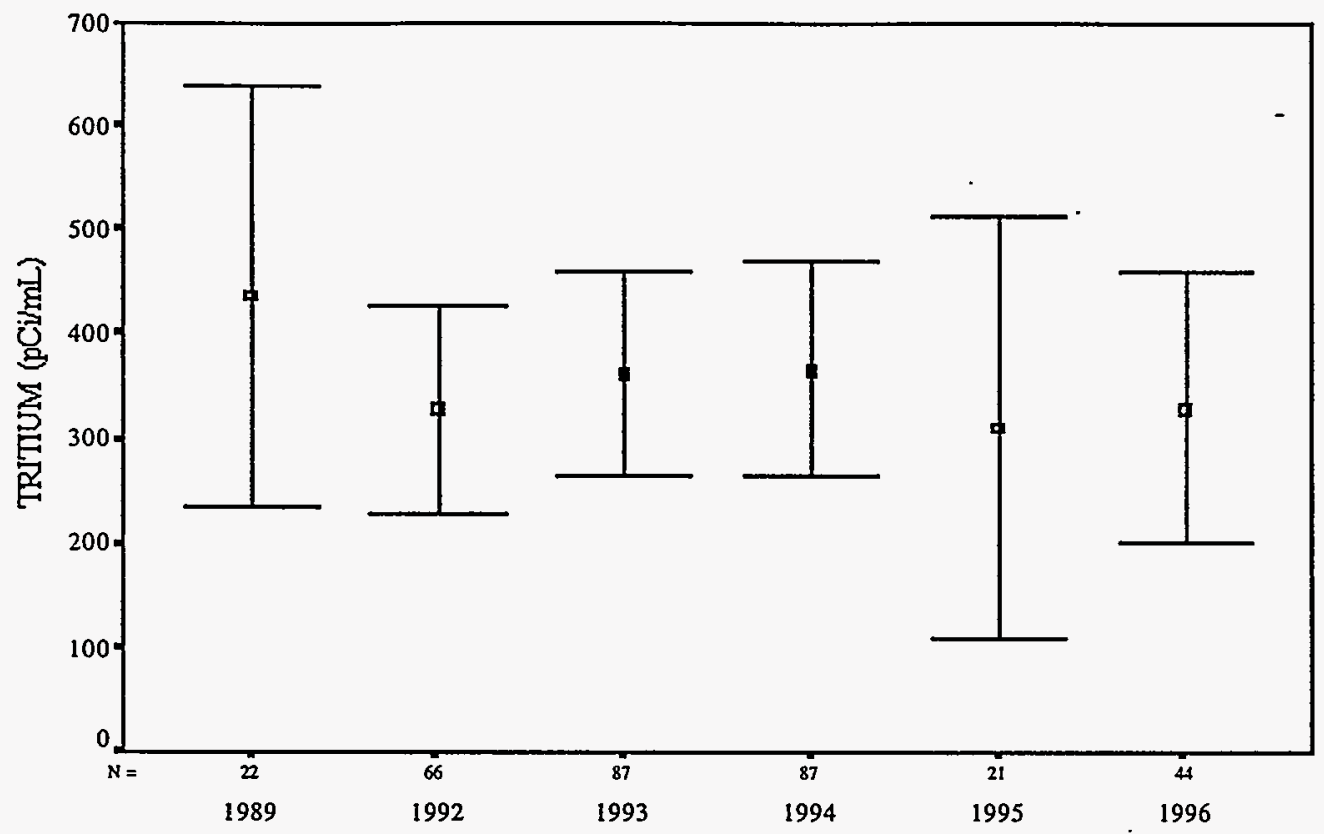

FIGURE 8. Mean radioactivity ( $\mathrm{pCi} / \mathrm{mL}$ ) and $95 \%$ confidence intervals of tritium at the F-Area Seepline, 1989-1996.

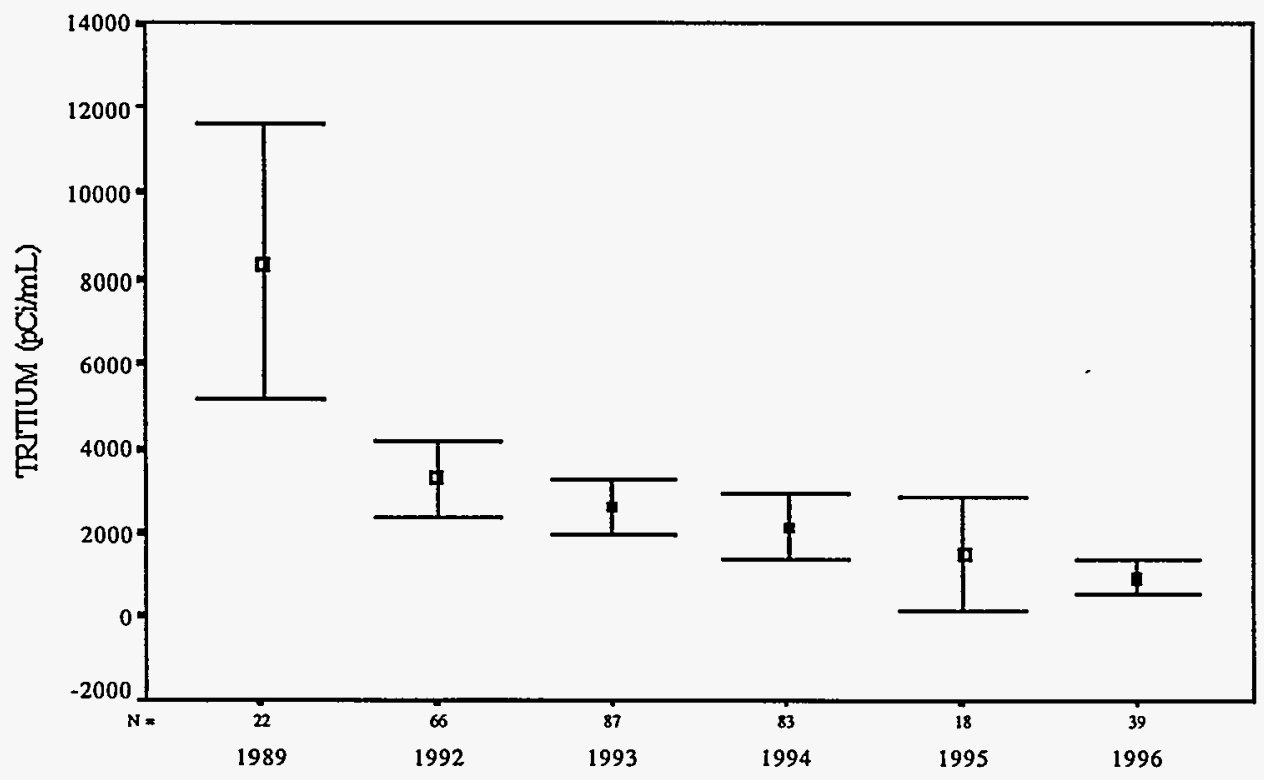

FIGURE 9. Mean radioactivity ( $\mathrm{pCi} / \mathrm{mL}$ ) and $95 \%$ confidence intervals of tritium at the $\mathrm{H}-\mathrm{Area}$ Seepline, 1989-1996. 


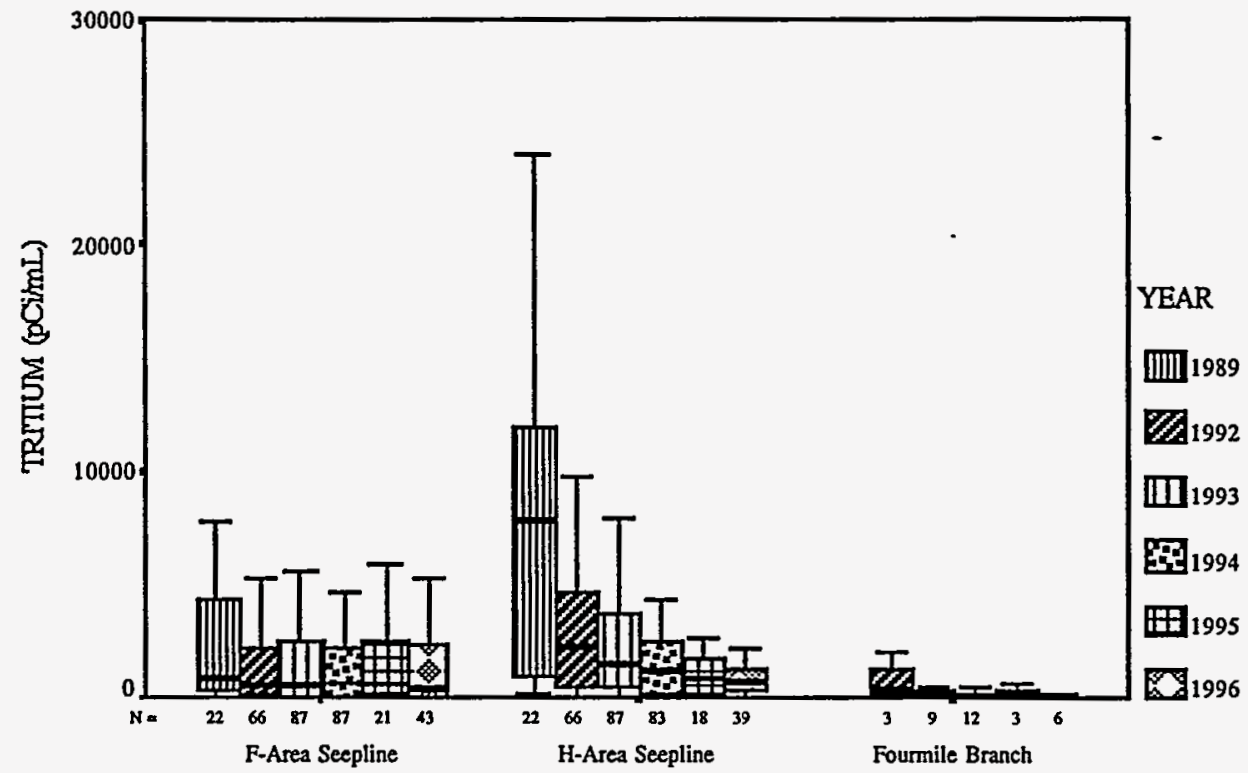

FIGURE 10. Tritium radioactivity $(\mathrm{pCi} / \mathrm{mL})$ at the $\mathrm{F}$-and $\mathrm{H}$-Area Seeplines and Fourmile Branch, 1989-1996.

\section{Hydrogen Ion Activity (pH)}

The activity of hydrogen ions in water is typically expressed in logarithmic units, and the abbreviation "pH" represents the negative base-10 log of the hydrogen-ion activity in moles per liter (Hem 1989). The pH of pure water at $25^{\circ} \mathrm{C}$ is 7.00 , and most groundwater in the United States ranges between 6.0 and 8.5 (Hem 1989). Strom and Kaback (1992) reported a range of 4.9 to 7.7 for the coastal plain of South Carolina whereas Railsback et al. (1996) gave a range of 6.3 to 7.7 in the coastal plain of Georgia. The $\mathrm{pH}$ of groundwater and surface water in the vicinity of the FHSB is important because it can influence the availability and mobility of metals, which in turn, can affect human health and the environment.

Boxplots of pH values at the seeplines and at Fourmile Branch are shown in Figure 11. From 1989 to 1996, the $\mathrm{pH}$ ranged between 2.9 and 7.0. Median values were lowest at the F-Area seepline, intermediate at the $\mathrm{H}$-Area seepline, and highest in Fourmile Branch. These results may be associated with greater releases of nitrates in F-Area as compared to H-Area, and also due to greater dilution in Fourmile Branch. 


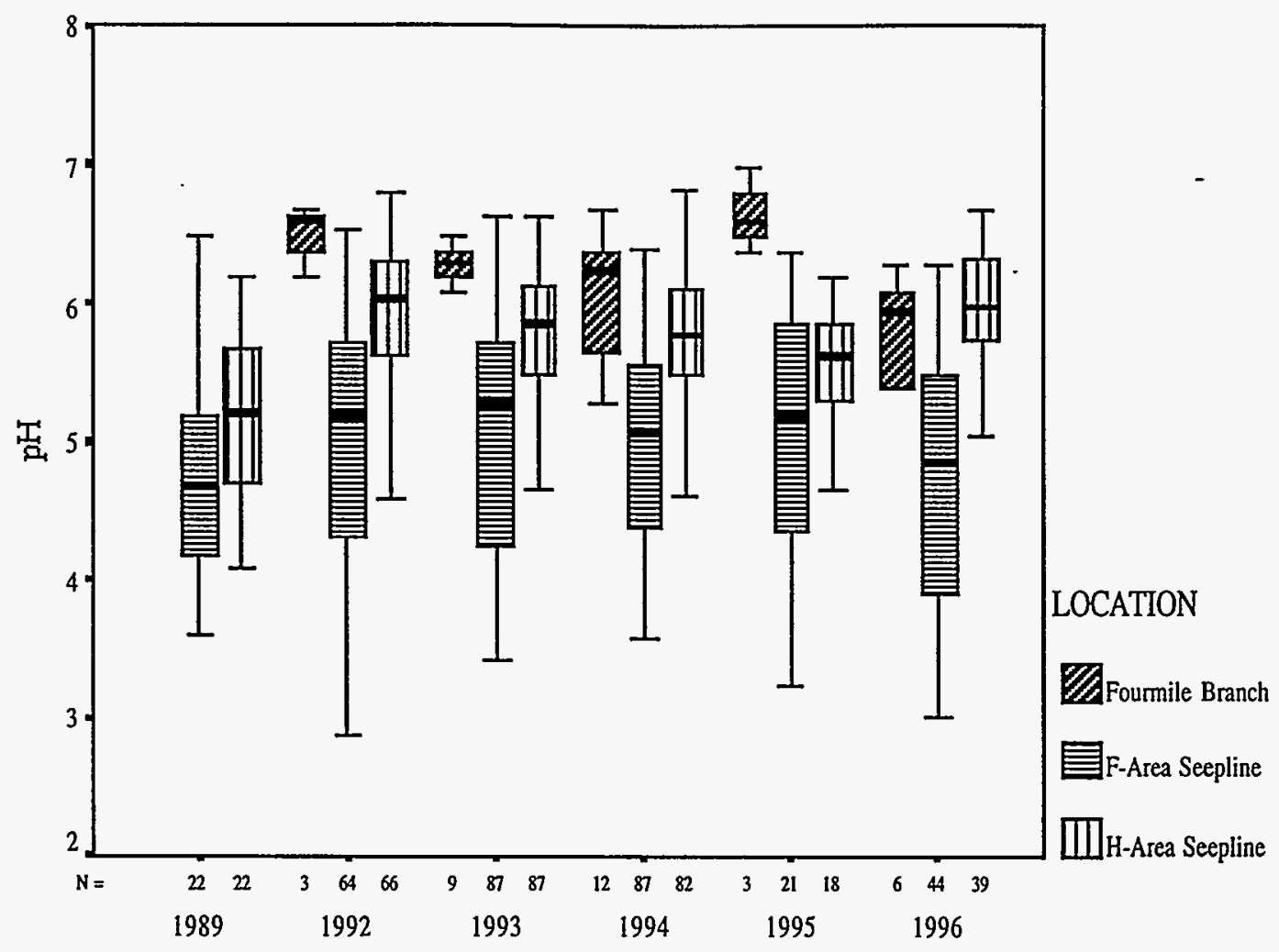

FIGURE 11. Boxplots for pH at the F-and H-Area Seeplines and Fourmile Branch, 1989-1996.

\section{Conductivity}

Electrical conductance (i.e., conductivity), which refers to the ability of water to conduct an electric current, is measured in microsiemens per centimeter (Hem 1989). When measured at a specified temperature, conductivity is called specific electrical conductance. SRS conductivity data are based on a temperature of 25 ${ }^{\circ} \mathrm{C}$. Conductance measurement provides an indication of ion concentration and has been used as a general indicator of plume differentiation between the FHSB and the burial ground. From 1989 to 1996 , the mean conductivity ranged from $65 \mu \mathrm{S} / \mathrm{cm}$ in Fourmile Branch to $354 \mu \mathrm{S} / \mathrm{cm}$ at the F-Area seepline (Table 7). For both the F-Area and $\mathrm{H}$-Area seeplines, there was a correlation between conductivity and tritium. Spearmañ correlation coefficients were $0.92(\mathrm{P}<0.01)$ for F-Area $0.76(\mathrm{P}<001)$ for H-Area.Conductivity at the F-Area seepline was relatively consistent from 1989 to 1996 (Figure 12). At the H-Area seepline, however, conductivity has steadily declined since 1989 (Figure 13).

TABLE 7. Mean conductivity $(\mu \mathrm{S} / \mathrm{cm})$ and $95 \%$ upper confidence intervals (UCI) at the F-and H-Area Seeplines and Fourmile Branch, 1989-1996.

\begin{tabular}{lccc}
\hline \hline Location & $\mathbf{n}$ & Mean & 95\% UCI \\
\hline F-Area Seepline & 327 & 354 & 403 \\
H-Area Seepline & 314 & 168 & 182 \\
Fourmile Branch & 33 & 65 & 74 \\
\hline
\end{tabular}




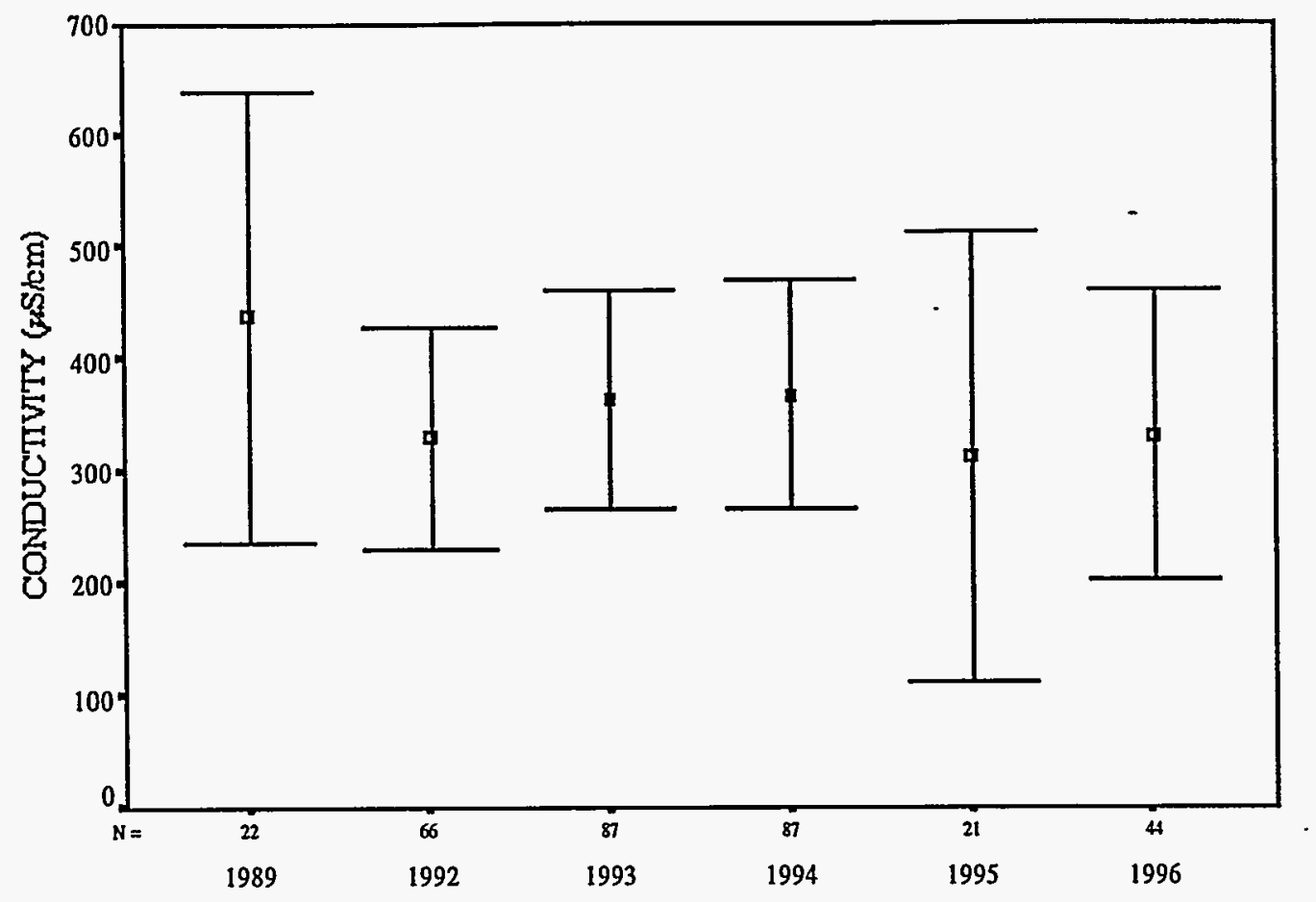

FIGURE 12. Mean and $95 \%$ confidence interval of conductivity $(\mu \mathrm{S} / \mathrm{cm})$ at the F-Area Seepline, 1989-1996.

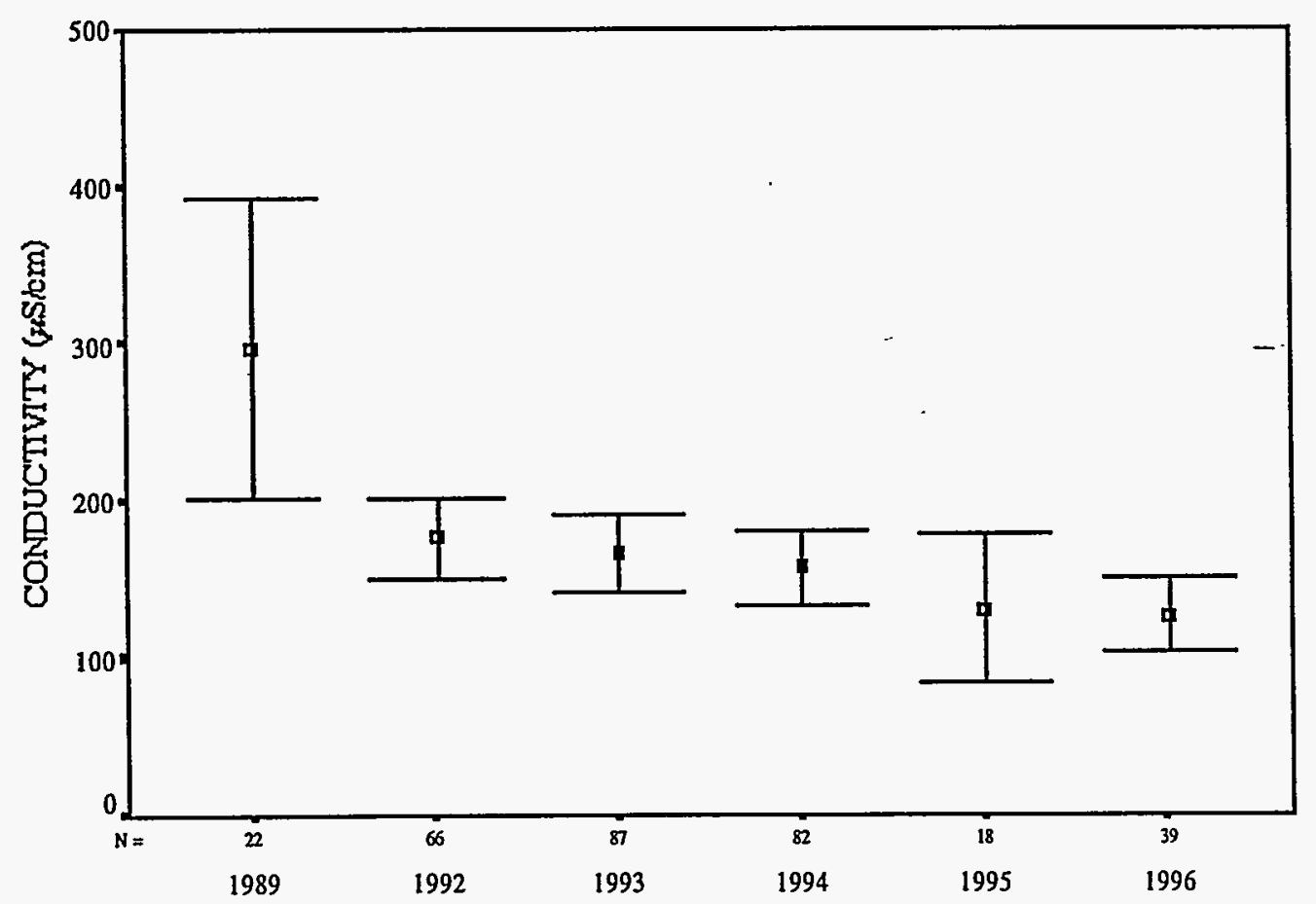

FIGURE 13. Mean and $95 \%$ Confidence Intervals $(95 \%)$ of conductivity $(\mu \mathrm{S} / \mathrm{cm})$ at the $\mathrm{H}-\mathrm{Area}$ Seepline, 1989-1996. 


\subsubsection{Water Table Monitoring}

The proposed remedial action at the FHSB could alter the existing hydrology. In some areas, this could reduce soil moisture within the root zones of vascular flora. This could affect vegetative structure and the availability of wildlife habitat. In order to assess possible impacts to the wetlands, a network of 20 piezometers (12 in FArea and 8 in H-Area) was installed in January and May 1996 (Figure 13). The objective of this program was to establish baseline hydraulic head data and to permit the monitoring of water table elevations after remedial actions commence. From January to August 1996, water table levels have been relatively stable (Dixon 1996b).

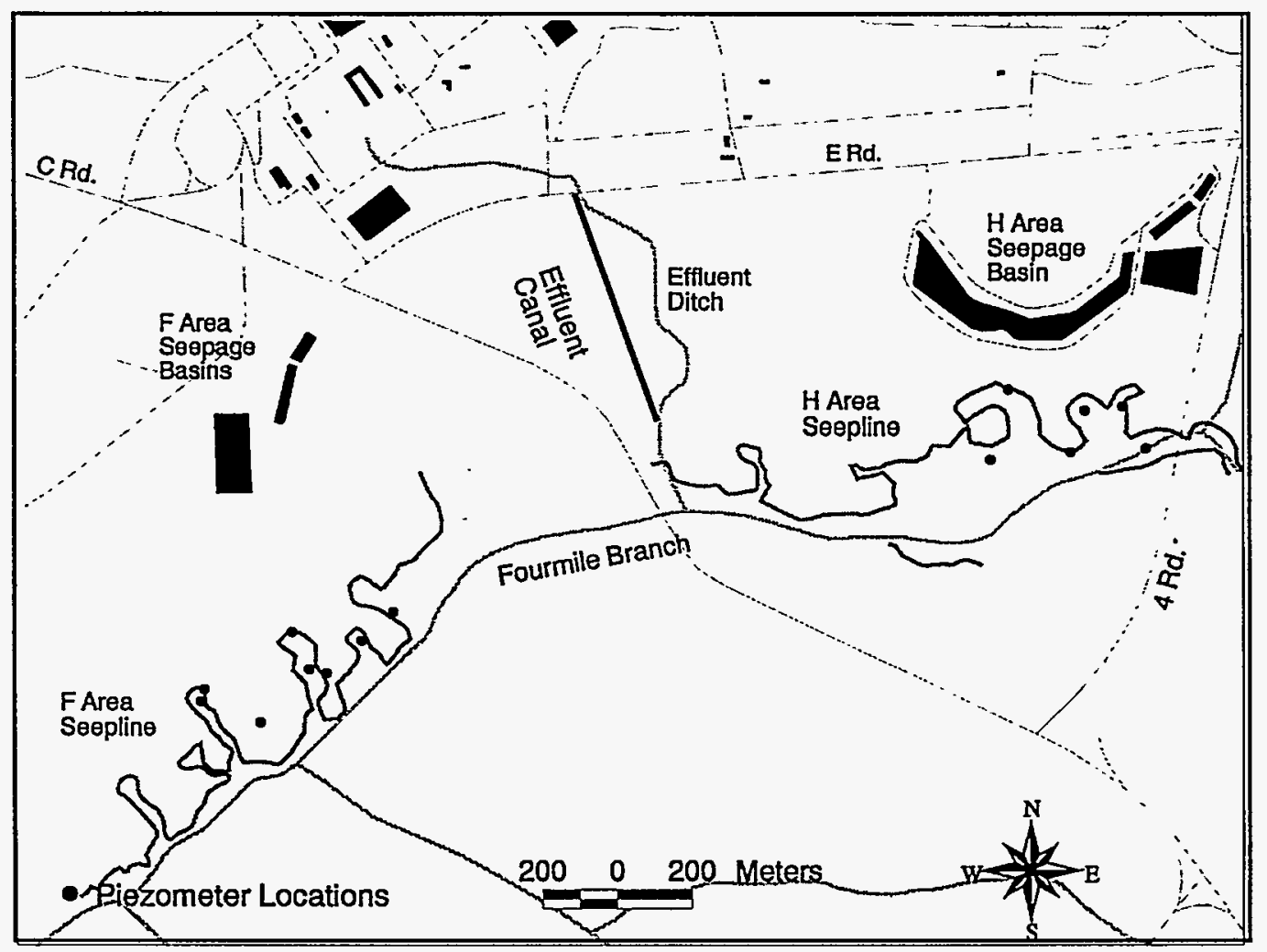

FIGURE 14. Distribution of piezometers at the F-and H-Area Seeplines.

\subsubsection{Remote Sensing}

The existing remote sensing data base for the F-and H-Areas consists of various applications dating back to 1938. Airborn gamma surveys, which are used to monitor low-level contamination patterns, were conducted for 1974, 1979, 1982, and 1991. Multispectral scanner data, which are useful in examining vegetative stress patterns, exists for 1981 and for the period 1983-1996. Historic aerial photography includes three years (1938, 1943 , and 1951) before the SRS was constructed. Post-SRS black and white imagery exists for 1956, 1961, 1966, 1973, and 1974. False color infrared and normal color aerial photography was taken from 1978 to 1996. Aerial obliques, video, and satellite (SPOT) information are also available for the 1980 s and 1990 s. Remote sensing information can be used to reconstruct historical events and examine former waste management practices. It is also useful for monitoring vegetative change, particularly canopy mortality and succession, over time. 


\subsection{Biotic Investigations}

\subsubsection{Vegetation}

Observations of arboreal mortality in bottomland hardwoods between the FHSB and Fourmile Branch have been documented by Mackey (1988), LeBlanc and Loehle (1990), Greenwood et al. (1990), Lohle (1990 a,b,c), Parker et al. (1990) and others. In spring 1990, a survey of Fourmile Branch was conducted to characterize the radiological condition of the stream and stream valley (WSRC 1991a). Ferns and timber were analyzed for levels of gross alpha, gross beta, cesium, cobalt, strontium, and tritium.

Loehle (1990a) sampled areas exhibiting canopy mortality near the FHSB and also conducted toxicity tests using lettuce seedlings on leachate from seepline soils. Although Loehle (1990a) found soil leachate to be toxic, he concluded that continued leaching improved soil quality.

Greenwood et al. (1990) reviewed SRS data and information in the open literature on contaminant chemistry and toxicology in trees in an attempt to determine the cause of tree mortality observed in the F- and H-Areas. The study focused on three possible causes of stress, namely altered hydrology, hazardous chemicals, and nonhazardous chemicals. Greenwood et al. (1990) concluded that severe drought in 1977 played a role in the observed tree stress. Dry conditions may have exacerbated stress caused by chemicals present in the soils by concentrating them further. Salt and heavy metal concentrations were elevated in soil at each impacted site. Aluminum was identified as probably the most toxic metal at F-Area. However, cadmium, manganese, and zinc were present at concentrations high enough to be considered possible causes of tree mortality. Aluminum was thought to be the most likely cause of tree mortality at H-Area.

LeBlanc and Loehle (1990) analyzed tree-rings to determine causes of vegetative stress at FHSB. Chemical analyses of the cores failed to provide conclusive evidence of temporal changes in the soil chemical environment associated with groundwater contamination. Observed increases in aluminum concentrations during the 1978-1987 period were consistent with the expected effects of acidic contaminants on soil solution chemistry. However, this effect was not corroborated by increases of manganese, also expected as a result of soil acidification. Tree ring analysis indicated that severe droughts occurred in 1977 and 1986.

Dames and Moore (1991) characterized wetland vegetation near Fourmile Branch using stratified plots, but this study did not include the tree-kill areas in the vicinity of FHSB. Loehle (1990c) performed a cluster analysis using the Dames and Moore (1991) data but failed to identify any contamination patterns. Vegetative stress and low species richness, however, were reported.

In the spring of 1993, V.A. Rogers (unpublished) delineated the jurisdictional wetlands north of Fourmile Creek (Figure 15) in accordance with U.S. Army Corps of Engineers protocol (USACOE 1987). For an area to be declared a jurisdictional wetland, hydrophytic vegetation, hydric soils, and wetland hydrology must be present. Survey flags were placed along the boundary of the wetlands and these locations were subsequently surveyed. The jurisdictional wetlands (Figure 15) were delineated using coordinates (Appendix A) from the survey.

\section{Seed Germination Studies}

Eaton and Murphy (1993) also tested the toxicity of F-Area seepline soil leachate using lettuce seedlings. Their study, which was designed to evaluate changes in toxicity from those reported by Loehle (1990a), revealed no significant differences in germination between the treatments but radicle length was markedly reduced by the first extraction from seepline soils. Continued seed germination studies have shown that extracts of wetland soils generally reduce seed vigor.

In a subsequent study by Nelson and Westbury (1994), the growth response, as measured by seed germination and root elongation, to leachates (first and sixth water washings) from the impacted soils of F-Area were compared to uncontaminated wetland soils and distilled water. This study measured both the number of seeds that 


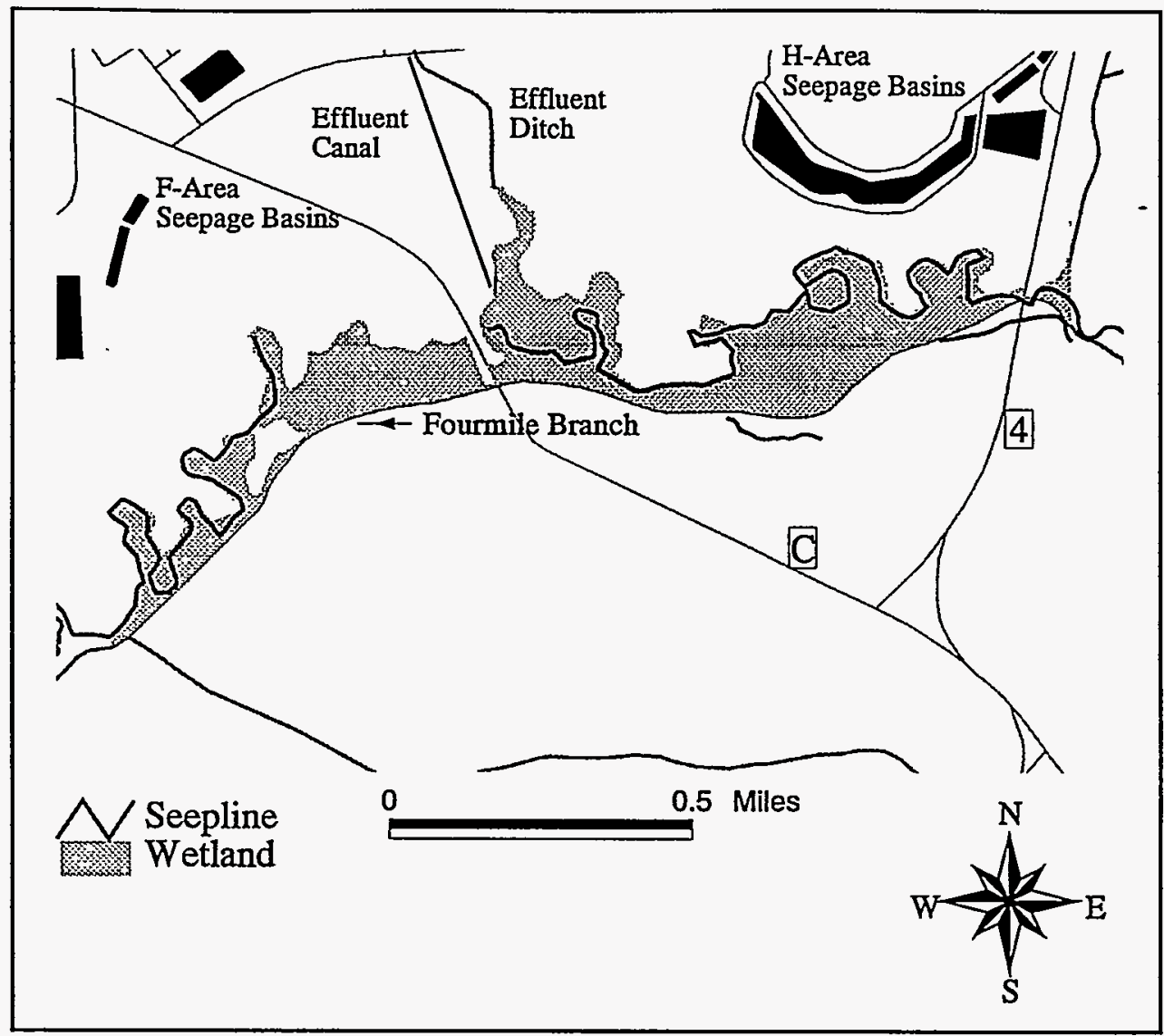

FIGURE 15. Distribution of jurisdictional wetlands below the F-and H-Areas as determined by field surveys in 1993.

germinated and the elongation of the root and hypocotyl during the 72 hour test. Statistical differences in germination rates due to water samples in this study were not significant at the $95 \%$ confidence level. Germination of seeds from the control, blank, and sixth wash of the F-Area samples were similar in 1994 to the results from 1990. Germination order among the treatments were similar over the three years tested. De-ionized water generally produced the greatest germination values, with sixth wash values of the F-Area being nearly equal. First wash treatments were generally lower, especially for the F-Area in previous studies. Much of the toxic effect on seed germination of this sample has been reduced over the years.

The analysis of the variation in root elongation found significant differences between treatments. A Tukey multiple comparison analysis found that the first wash treatments from the F-Area and the control area were different from the de-ionized water blank. No other differences were significant at the $95 \%$ confidence level, including between F-Area first wash and the control.

First washes of these wetland soils have generally reduced root elongation in each of the years tested (Table 8). It is possible that these wetland soils possess a component that naturally suppresses lettuce seed germination, above and beyond the chemical toxicity of the impacted soils tested. The sixth wash of the impacted soil generally produced higher germination and greater elongation than the first wash of the control soil and nearly as good as the de-ionized water sample.

This study showed a greatly reduced toxic effect of the leachate from F-Area seepline soil samples over time on lettuce seed germination and growth as compared to control samples from an uncontaminated site. This 
TABLE 8. Germination (\%) and root elongation (mm) results, 1990-1994.

\begin{tabular}{lcccccc}
\hline \hline Treatment & \multicolumn{3}{c}{ Germination (\%) } & \multicolumn{3}{c}{ Root Elongation (mm) } \\
& $\mathbf{1 9 9 0}$ & $\mathbf{1 9 9 3}$ & $\mathbf{1 9 9 4}$ & $\mathbf{1 9 9 0}$ & $\mathbf{1 9 9 3}$ & $\mathbf{1 9 9 4}$ \\
\hline First Wash (F-Area) & 44 & 90 & 84 & 7.6 & 4.1 & 8.8 \\
Sixth Wash (F-Area) & 85 & 98 & 86 & 10.3 & 9.6 & 11.2 \\
Control & 75 & 94 & 75 & 11.8 & 6.0 & 9.2 \\
Deionized Water & 95 & 94 & 91 & 12.2 & 11.3 & 11.7 \\
\hline
\end{tabular}

Continuation of the testing work has led to the development of an on-site root elongation technique that does not require removal of materials for testing. This results in a test of the natural site condition in place and avoids the laboratory testing phase. This allows the larger scale testing of the entire tree-kill areas in the field. As part of this effort, additional water chemistry collection has shown that the seepline water coming into the tree-kill areas is less toxic than the water within the area but is more toxic than the background wetland area. This indicates that there are some residual affect within the tree-kill zones that have not been completely reduced, as well as affect from continuing inputs from the seepline into the system.

\section{Revegetation Studies}

Vegetation of two wetland areas (one in F-Area and one in H-Area) previously adversely affected by outcropping groundwater were characterized to evaluate the type and extent of revegetation (Nelson and Irwin 1994). The two areas examined in 1993 were the most severely affected ones in the F-Area and the H-Area. These areas are among those previously described and sampled in the 1980's. Prior to damage the sites were pure swamp tupelo (Nyssa sylvatica var. biflora) stands. All mature individuals were killed by the stress that occurred in the wetland areas. No overstory, other than a few widely scattered individuals, remained in either location.

A series of permanent vegetation characterization plots were installed to quantify the recovery. These plots were circular milacre plots ( $43.56 \mathrm{sq} . \mathrm{ft} / \mathrm{plot}, 4.05 \mathrm{sq} . \mathrm{m} / \mathrm{plot}$ ) installed at uniform intervals along transects in the two areas. Within each plot, all individuals were identified to species, where possible. Initial sampling took place in August and September 1993. Forty plots were examined in the F-Area along 4 parallel transects and 56 plots were examined in the H-Area along a single transect. Plot data were summarized to indicate qualitative and quantitative information about the current status of the two tree-kill areas sampled.

The substrate within the F-Area tree-kill location consisted of thick, flocculent, deep, muck with water flowing through it; algae grew on its surface. Vegetation within the F-Area tree-kill area was sparse. The canopy had been almost totally destroyed; only a few live trees remained. Some standing dead trunks and many fallen trunks were scattered throughout the area. Most of the existing understory vegetation was growing in widely scattered clumps on stumps, fallen logs, and accumulated debris. An occasional herbaceous wetland plant was noted growing in the muck near the upland edge of the tree-kill area. Twenty six species were encountered in the first sampling. Of the 40 plots sampled, seven (17.5\%) were totally devoid of vegetation. Transect 1 , closest to the source of the groundwater discharge and farthest from the surrounding forest, contained the fewest species (11), and the least number of individuals in all vegetation layers. Transects 2, 3 and 4 contained approximately the same number of species. Transect 4 , which was closest to the adjacent forest and Fourmile Branch, contained the highest number of tree seedlings (69 individuals versus 22 or less in each of the other transects).

Soil in the H-Area tree-kill zone was much more consolidated than the soil in the F-Area site. Much of the area had standing water at the surface. Depth increased as the plot number increased along the transect. Very few canopy trees were still alive. Some standing dead trees were evident and many logs were on the ground throughout the area. A total of 40 species was identified in the H-Area sampling location. The affected area 
had two distinct characterizations. Plots 1 through 15 were less wet and showed evidence of revegetation by woody species. The plots were clearly impacted previously, but were recovering much faster than plots 16 through 56. Plots 16 through 56 were much wetter and dominated by cattails (Typha sp.) and cut grass (Leersia oryzoides).

The sparse vegetation of the F- and H-Area tree-kill areas was in stark contrast to the adjacent forest. The species composition was similar, but the structure was very different. Unlike a relatively undisturbed forest, the tree-kill areas were not stratified. The species normally associated with canopy, subcanopy, and shrub layer were present in the F-Area, but as sickly seedlings perched above the substrate on stumps, logs, and piles of debris. None of the species are can survive continuous deep flooding that is typical of these areas. Therefore, without the stumps, logs, and debris, the vegetation could not exist. The adjacent forest, however, was characterized by a closed canopy of mature mixed hardwoods and loblolly pine (Pinus taeda). The subcanopy and shrub layers were intact and well defined; the plants were growing on a consolidated soil more characteristic of these wetland areas.

The composition of the first 15 plots of the H-Area tree-kill area indicated that the section was beginning to re-establish itself as a bottomland hardwood forest. Many years will be needed to allow the canopy to form a self-perpetuating forest. The hydrology of the remainder of the $\mathrm{H}$-Area tree-kill area and the lack of tree and shrubs indicated that the area was not suitable for natural regeneration of the bottomland hardwood forest.

The vegetation characterization plots were reassessed in June of 1994 to determine if any improvement had occurred in the additional year (Westbury and Nelson 1994). The F-Area site exhibited minimal plant community development. Most of the vegetation was growing on or near woody structured and elevated areas where the roots were above the saturated sediments. Thirty plant species were identified in 1994 in the F-Area plots, and were similar in composition to the 26 species found in 1993. Between 1993 and 1994, the number of woody plants increased three-fold. This increase was especially pronounced in plots on Transect 4 . This transect accounted for over half of the woody plants found in the area, as was the case in 1993. Red maple seedlings (Acer rubrum) accounted for the largest increase in numbers of individuals. If the survival rate of these seedlings is good and they can establish roots in the saturated sediments, the substrate could become more consolidated and amenable to colonization by wetland plants. In general, this site was devoid of flora, with only $8 \%$ herbaceous cover and very small tree and shrub seedlings confined to dryer locations. There was no evidence of the development of a herbaceous wetland plant community, which would indicate a reduction of the toxicity of the sediments in the tree-kill zone. Virtually all plants growing within the F-Area tree-kill zone were rooted out of the saturated sediments.

The H-Area tree-kill site substrate was again found to be much more densely vegetated with more consolidated sediments of a higher organic content than the F-Area site in the 1994 characterization. Extensive development of a herbaceous wetland plant community indicated that the toxicity of the sediments had been reduced considerably. The general character of the plants in the area did not show signs of stress and the high percent coverage indicated minimal impairment of plant establishment and growth. In 1994, 50 plant species were identified in the study plots, as compared to 40 in 1993. Species composition was similar in both studies, with most of the increase due to the difference in the sample dates with respect to season. The total herbaceous cover of the H-Area plots decreased from $93 \%$ in 1993 to $77 \%$ in 1994. The largest decrease was with the two most frequent and dominant species; cattail decreased from 54\% in 1993 to $40 \%$ in 1994, whereas cutgrass decreased from $30 \%$ in 1993 to $18 \%$ in 1994 . The decrease in percent cover of these two species was probably due to the 1994 sample being taken earlier in the growing season (June) than in 1993 (September). Ten additional plant species were measured in 1994. Most of these additions were also attributed to the earlier sample date because the plants were in flower and could be identified to species, or, as with bishop-weed (Ptilimnium capillaceum) the plant flowers and senesces early in the season. The increase in herbaceous plant species numbers was insignificant.

The H-Area tree-kill site had developed an extensive post-disturbance plant community dominated by herbaceous wetland plants. After the swamp tupelo canopy was removed by the initial impact, wetland herbaceous species should colonize the saturated sediments as soon as the toxicity of the sediments became sub-lethal. 
With time, shrub and tree species would become dominant, eventually returning to the pre-disturbance composition. The northern portion of the zone (plots 1-20) had developed a sub-canopy of shrubs and saplings indicating a more advanced successional stage than the remainder of the zone. The principal tree species present was red maple, an early successional invader. The intermediate section (plots 21-35) was dominated by southern cattail as opposed to broad-leaf cattail in the more open western section (plots 36-56). This abrupt shift in species composition may be due to variations in hydrology, light availability, or $\mathrm{pH}$.

General conditions at both tree-kill zones were unchanged between the 1993 and 1994 studies. Differences due to sampling date were observed. Future characterization should be on a standardized date to reduce this variability. The F-Area site exhibited toxicity in the saturated sediments, and was largely devoid of vegetation with only $8 \%$ herbaceous cover. The typically three-fold increase in tree, shrub, and vine seedlings was a positive sign, although general vigor and health of the new individuals was poor. If the survival rate of these seedlings is good and they are able to send roots into the saturated sediments, then the substrate could become more consolidated and amenable to colonization by wetland plants.

The H-Area site exhibited far greater plant community development and successional recovery than the FArea site. The presence of a shrub sub-canopy in the northern and middle portions of the zone, and the generally high percent cover (77-93\%) of herbaceous wetland plants, indicate lowered toxicity of the substrate to germination and establishment of vegetation.

In 1994, Nelson and Rogers (1995) initiated efforts to re-establish native vegetation in several of the tree kill areas. In an effort to reestablish the climax species of the area, swamp tupelo (Nyssa sylvatica var. biflora) seedlings were planted in four of the impacted areas. The four areas were named for the seepline water sampling point nearest to them. The areas represented a gradient of impact level to the vegetation, with F14 and F47 being most severely damaged, F204 the least damaged, and H38 as intermediate. Natural revegetation of the areas reflects the original damage level, with little revegetation at F14 and F47, early successional species invasion of $\mathrm{H} 38$, and a moderate shrub and herbaceous layer occurring in F204. Each of the study areas was planted with swamp tupelo seedlings in early February 1994. An initial survival tally of the seedlings was taken on June 7, 1994, and indicated that healthy seedlings had been planted into the areas. Seedlings were placed into categories ranging from 1 for a healthy seedling to 4 for a dead seedling. A late season tally of the seedlings was conducted September 13, 1994 using the same classes of seedling condition. This tally was used to determine how well the seedlings had performed in their new environment. Subsequent tallies have been made each spring and fall to track the performance of the seedlings.

Survival of swamp tupelo seedlings after the first field growing season was excellent on all four of the affected sites examined. The first year after planting is characteristically spent by the seedling establishing contact with it's new environment.

During the second growing season, the two sites which had less severe original impacts, F204 and $\overline{\mathrm{H}} \overrightarrow{\mathrm{B}}$, still showed good survival and general condition of the seedlings. The two sites which experienced the greatest original tree-kill, F14 and F47, also had good over-winter survival. The percentage of trees that appeared stressed, however, had increased from the tally at the end of the first growing season for these two sites. Subsequent observations of F14 and F47 sites during the growing season indicated that seedling condition was deteriorating. Observations at the start of the third season of growth clearly confirmed this. The two sites which had less severe original impacts, F204 and H38, still showed good survival and general condition of the seedlings. The two sites which experienced the greatest original tree-kill, F14 and F47, continued to show the effects of the environment which were noted during the middle of the second growing season. Both of these areas experienced a greater than 20 percent decline in survival between the second and third growing seasons, as was anticipated after the mid-season evaluation. This continued decline is seen in Figure 16, which indicates the percent survival of the tupelo seedlings at the beginning of the first, second, and third growing seasons. 


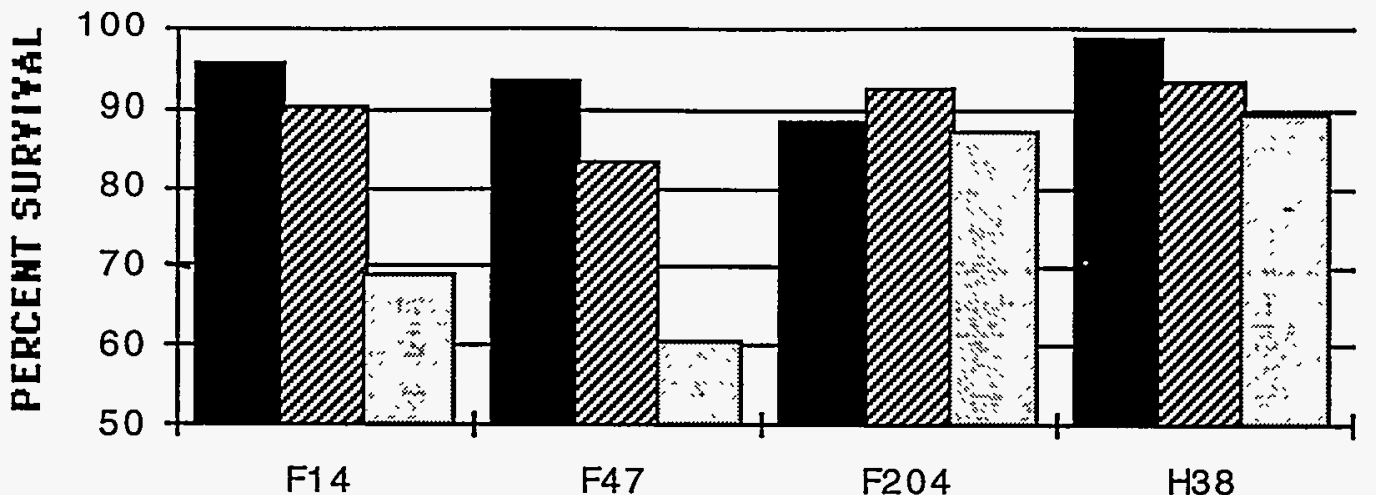

\section{Spring 94 Spring $95 \square$ Spring 96}

FIGURE 16. Percent survival of seedlings in four wetland areas, 1994-1996.

\subsubsection{Macroinvertebrates}

Macroinvertebrates include immature, aquatic insects such as mayflies, stoneflies, and caddisflies. These species spend the first part of their lives under water, breathing oxygen via gills and burrowing into the sediment. Macroinvertebrates are excellent indicators of environmental health and are not commonly found where contamination prevails. Numerous investigations of macroinvertebrates have been conducted on the SRS.

Firth et al. (1986) sampled macroinvertebrates monthly at 29 sites in the SRS stream and swamp areas using Hester-Dendy multiplate samplers placed in the streams. Species richness, density, and biomass were recorded for each sample, and invertebrates were sorted into functional feeding groups. Density and species diversity of macroinvertebrates at Fourmile Branch were either the highest or among the highest observed at the nonthermal stream sites. The Fourmile Branch location also exhibited the highest biomass of collectorfilterer organisms and a relatively low biomass of predators. The dominance of collector-filterer organisms in Fourmile Branch indicated that the trophic structure in the stream was supported by fine particulate organic detritus, possibly related to the presence of beaver ponds throughout the drainage (Gladden 1988). A high degree of biological processing of this organic matter is considered a desirable feature. The reason behind the relative absence of predators in Fourmile Branch was not clear. Gladden (1988) concluded that the macroinvertebrate community in Fourmile Branch was similar to the trophic structure of macroinvertebrate communities in upper Pen Branch and Meyers Branch, both of which have not been adversely affected by SRS operations.

Lauritsen et al. (1989) examined macroinvertebrates in Fourmile Branch between June 1985 and September 1987 as part of a larger study of SRS streams. They found that following the shut down of C-Reactor, recolonization of the stream by macroinvertebrates began within a month and proceeded rapidly. It was also noted that this phenomenon occurred in summer, the peak reproductive period for macroinvertebrates.

Specht (1994) examined macroinvertebrates at six locations in Fourmile Branch during the summer of 1993. The diversity and abundance of macroinvertebrates in Fourmile Branch at Road C indicated stressed conditions. It was concluded that these conditions were attributable to low dissolved oxygen concentrations (4.0 $\mathrm{mg} / \mathrm{L}$ ) rather than discharges from FHSB. The 1993 study showed longitudinal trends with respect to most of the parameters that were measured. In general, environmental stream quality appeared to improve in a downstream direction. 
Specht and Paller (1995) sampled 16 SRS streams including Fourmile Branch at Road C for macroinvertebrates in September 1994. Although dissolved oxygen at this location was $4.9 \mathrm{mg} / \mathrm{L}$ and species richness and biomass $\left(\mathrm{g} / \mathrm{m}^{2}\right)$ ranked third and 13 th, respectively, Fourmile Branch in the vicinity of Road C was perturbed compared to other SRS streams.

\subsubsection{Fish}

The principal aquatic habitat for fish in the vicinity of FHSB is Fourmile Branch and its tributaries. Aquatic habitat associated with the seeplines are generally unsuited for fish, except during periods of flooding. Several studies have examined fisheries resources in the general area. Gladden (1988) summarized two fishery studies conducted by Environmental \& Chemical Sciences (ECS, unpublished) and Aho et al. (1986). Fish samples were collected in Fourmile Branch by ECS between December 1984 and August 1985 whereas Aho et al. (1986) sampled nine nonthermal streams from March 1984 to December 1985. Both studies used electroshocking equipment to collect samples. All but one of the stream sites were dominated by minnows, with the degree of dominance at these sites ranging from 41 to 63 percent. Fourmile Branch ranked at the lower end of this scale.

Because species richness of fish in Fourmile Branch was similar to other SRS sites, Gladden (1988) concluded that the fish communities in nonthermal reaches of Fourmile Branch had not been affected by effluent discharges. However, there was evidence that seepline and stream water have been occasionally toxic. Several metals have been commonly detected in the tissue of fish inhabiting Fourmile Branch. However, the concentrations of most of these chemicals have not been correlated to seepage basin discharges. Results of fish community structure analyses do not indicate that fish in Fourmile Branch have been adversely affected.

Paller and Story (1990) examined the abundance, distribution, and tissue of fish in Fourmile Branch upstream and downstream of the FHSB. They reported that species richness and catch per unit effort below the contaminant discharge zone were higher than locations above the zone. Total catch per unit effort in Fourmile Branch was similar to results from Pen Branch.

Loehle and Paller (1990) analyzed the tissues from fish collected by Paller and Story (1990) to assess the bioaccumulation of metals from the seepage basins. Of the nine metals that were analyzed, only aluminum, chromium, mercury, selenium, and zinc were detected. In 1992, Paller et al. (1995) used rapid bioassessment methods to collect fishes in Fourmile Branch and reported evidence of degradation. To better understand the fisheries of Fourmile Branch, comprehensive studies are scheduled for 1997 to support the Integrator Operable Unit (IOU) evaluation. These studies will include: (1) characterization of community structure using rapid bioassessment techniques, (2) tissue analysis for radioisotopes, metals, and volatile chemicals, and (3) necropsies for assessing ecological stressors.

\subsubsection{Herpetofauna and Small Mammals}

Friday et al. (1994) examined the diversity and relative abundance of amphibians, reptiles, and small mammals in the vicinity of $\mathrm{F}$ - and $\mathrm{H}$ Areas in 1994. Amphibians were markedly more common than reptiles based on observation, frequency of capture, and auditory surveys. Eight of the thirteen species of amphibians that were captured or observed were identified near the F-Area canal. Reptiles inhabiting the area included the box turtle, rat snake, and four species of lizards (green anole, six-lined racerunner, five-lined skink, and ground skink).

Mammalian species richness was relatively low; the short-tailed shrew and cotton rat were the most frequently captured small mammal. Composite tissue samples from short-tailed shrews captured from two reference locations, the old F-Area effluent ditch, and the H-Area seepline were analyzed for radioisotopes and metals (WSRC 1995c). Concentrations of the five composite samples are given in Table 9. Body burdens of 22 constituents in shrews from the F-Area ditch exceeded background levels compared to 12 constituents analyzed from shrews at the H-Area seepline. 
TABLE 9. Body burdens of selected constituents in shrews (Blarina carolinensis) in the vicinity of the FHSB, 1995 (WSRC 1995c).

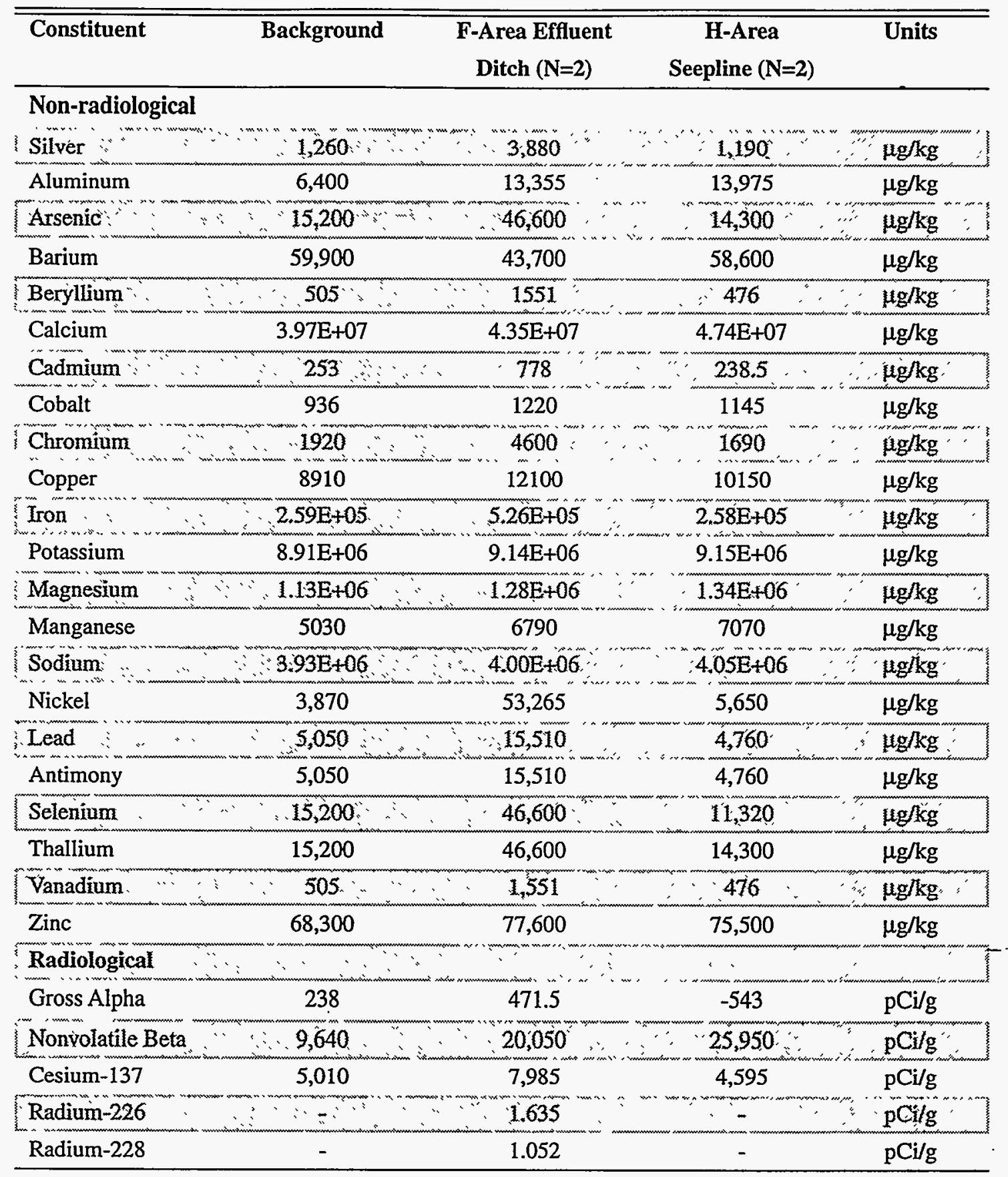

\subsubsection{Aquatic Toxicology}

Toxicity testing is the process of exposing test organisms to a medium (water, soil, sediment, or air) and evaluating the lethal or sublethal effects of contamination on the survival, growth, reproduction, or other biological functions. Toxicity tests can be acute or chronic. Acute toxicity tests are short-term tests that measure the effects of exposure to relatively high concentrations of chemicals. Chronic toxicity test are longer-term test that measure the effects of exposure to relatively lower, less toxic concentrations.Toxicity testing can usually confirm the presence of a toxicant, but it typically cannot identify the specific chemical. This can be accom- 
plished by a subsequent investigation, the toxicity identification evaluation (TIE). The principal objective of aquatic toxicology studies at SRS was to evaluate the effect of contaminated groundwater that surfaces at the F-and H-Area seeplines, flows through the wetlands, and enters Fourmile Branch.

\subsubsection{Chronic Aquatic Toxicity}

Chronic toxicity tests using EPA protocol were performed on surface water samples collected from 11 seepline locations and five locations in Fourmile Branch between May 1990 and July 1994 (Figure 17). In addition, surface water from five uncontaminated background locations was also tested. The distribution of sampling locations by year is summarized in Table 10. Locations denoted as. FSP and HSP represent F-and

TABLE 10. Distribution of aquatic toxicity sampling locations, 1990-1994 (Specht 1996).

\begin{tabular}{|c|c|c|c|c|}
\hline Location & 1990 & 1991 & 1993 & 1994 \\
\hline FSP-012 & - & & $\bullet$ & $\bullet$ \\
\hline FSP-032 & $\bullet$ & & $\bullet$ & \\
\hline FSP-047 & & & $\cdot$ & \\
\hline FSP-204 & & & $\bullet$ & $\bullet$ \\
\hline FSP-256 & & & - & \\
\hline HSP-008 & & & $\bullet$ & $\bullet$ \\
\hline HSP-020 & & & $\bullet$ & \\
\hline HSP-043 & $\bullet$ & & & \\
\hline HSP-060 & & & $\bullet$ & \\
\hline HSP-103 & & & $\bullet$ & $\bullet$ \\
\hline $\mathrm{H}-6$ & $\bullet$ & & & \\
\hline FMB Road 4 & & & $\bullet$ & \\
\hline FMB Road C & 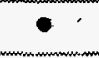 & & 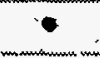 & \\
\hline FMB Road C-4 & $\bullet$ & & $\bullet$ & \\
\hline FMB SCE\&G & & & & - \\
\hline FMB Road A-7 & $\bullet$ & $\bullet$ & $\bullet$ & \\
\hline UTR-022 & & & & - \\
\hline UTR-029 & & & & $\bullet$ \\
\hline UTR-116 & & & & - \\
\hline BGW-045 & & & . & $\bullet$ \\
\hline UTR RR Bridge & & & & $\bullet$ \\
\hline
\end{tabular}

H-Area seepline sites, respectively. Sampling locations in Fourmile Branch are designated as FMB. The four background seepline locations include UTR and BGW sites. A background stream location, Upper Three Runs Creek (UTR) at the railroad bridge, was also sampled.

Definitive chronic toxicity tests were conducted on the water flea, Ceriodaphnia dubia, using EPA methods (Weber et al. 1989). Toxicity tests were performed on a series of dilutions, (generally $0,6.3 \%, 13 \%, 25 \%$, $50 \%$, and $100 \%$ sample water), using 10 test organisms per concentration. At the end of the 7-day test the reproductive success (number of young produced) of organisms exposed to each dilution was compared statistically to that the control group (0\%) in order to determine if reproduction was impaired. The results of the tests were reported as NOEC's (No Observed Effect Concentration), which represent the highest concentration that did not significantly reduce reproduction. A NOEC value of $100 \%$ means that no reproductive impairment was observed in the undiluted sample. In addition, any mortality that occurred during the test was 


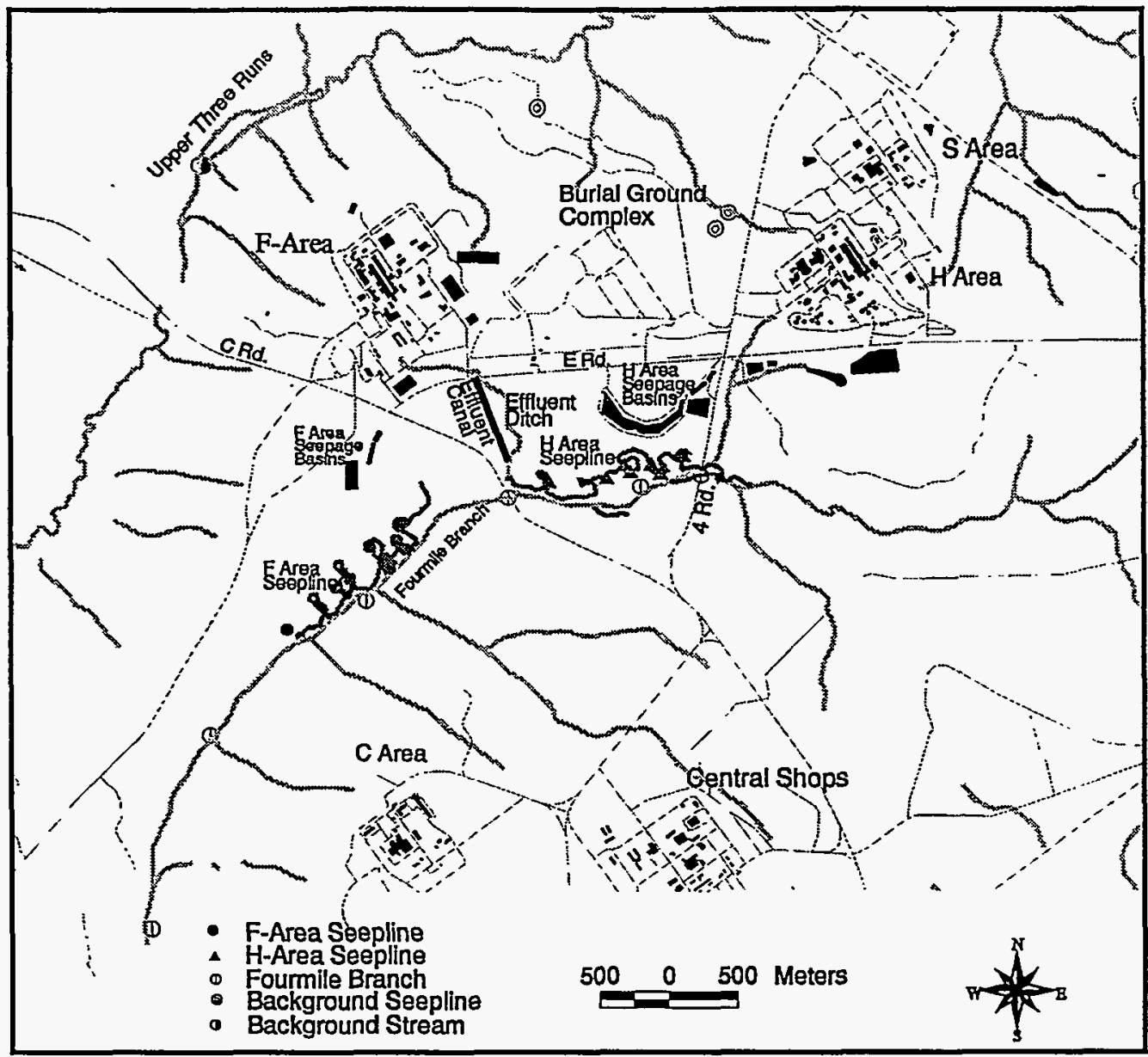

FIGURE 17. Distribution of toxicity sampling locations, 1990-1994.

also recorded.Water quality parameters routinely measured during the toxicity tests included temperature, $\mathrm{pH}$, hardness, alkalinity and specific conductance.

Toxicity tests were initially conducted in May and June, 1990. Six representative sampling locations were selected based on water chemistry analyses conducted by Haselow et al. (1990): (a) two at the F-Area seepline, (b) two at the H-Area seepline, and (c) two locations in Fourmile Branch (Table 10). Fourmile Branch at Road $C$ was selected because it occurs downstream from the $\mathrm{H}$-Area seeplines, yet upstream from the F-Area seepline. Fourmile Branch at Road C-4 was selected because it lies downstream from both seeplines. In November and December 1990, samples were collected at the same locations except for Fourmile Branch which was sampled at Road A-7 rather than at Road C-4 (Korthals 1991). The location at Road A-7 lies downstream from both the $\mathrm{F}$ and H-Area seepage areas (Figure 1). The results of the 1990 testing indicated the presence of toxicity at both seeplines and also in Fourmile Branch at Road A-7 (Table 11).

In July 1991, a second toxicity test was conducted on surface water collected from Fourmile Branch at Road A-7. These results, however, showed no evidence of toxicity in the stream (Table 11). Toxicity testing was not conducted for the F- and H-Area seeplines in 1991 nor was toxicity testing performed in 1992.

In September 1993, toxicity tests were conducted at five F-Area seepline locations, four H-Area seepline locations, and four locations in Fourmile Branch (Table 11). The seepline locations were selected based on 
water chemistry results of Dixon et al. (1993), and included several locations that were tested in 1990. The creek locations were selected to be upstream of the F- and H-Area seeps ( $\operatorname{Road} 4)$, between the F- and H-Area seeps (Road C), immediately downstream of most of the seeps (Road C-4), and downstream of all seeps (Road A-7). Except for a single location in H-Area, all seepline locations were toxic in 1993 (Table 11). No toxicity was detected in Fourmile Branch.

Toxicity testing was continued in 1994 at 10 locations: (1) two seepline sites in F-Area, (2) two seepline sites in H-Area, (3) one location in Fourmile Branch at the SCE\&G power line, (4) four background seepline sites, and (5) one background location in Upper Three Runs Creek. The results of these analyses indicated that seepline waters at F-and $\mathrm{H}$-Area were toxic, background seepline locations were slightly toxic, and Fourmile Branch and reference streams were not toxic. Compared to earlier observations, toxicity at some seepline locations appeared to decline.

Aquatic toxicity varied by location and year (Table 11). Toxicity results for background, seepline, and Fourmile Branch locations are summarized below.

Background Locations- Three of the four background seepline locations that were sampled in 1994 were toxic (NOEC values of 50\%). One seepline location and the single stream location in Upper Three Run Creek at the rail road bridge were not toxic. These results indicate that some seepline locations on the SRS, even though they are not influenced by the F-and H-Area seepage basins, can be toxic to Ceriodaphnia dubia.

Seepline Locations-Toxicity tests conducted on seepline locations downgradient from the F- and H-Area Seepage Basins had NOEC's ranging from $3 \%$ to $100 \%$ (Table 11). Of the eleven seepline locations that were sampled in 1993 and 1994, only two showed no evidence of toxicity (HSP-008 and H-6). The remaining locations were toxic on at least one occasion. The degree of toxicity at the seeplines seeps appears to vary temporally. The variation is probably related to the amount of rainfall in the week or two prior to sample collection. Rainfall can dilute the seepline surface water directly and can also infiltrate the shallow groundwater, causing further dilution.

Fourmile Branch-Between 1990 and 1994, surface water from five locations in Fourmile Branch was tested (Table 11). Of the ten toxicity tests that were performed, only Fourmile Branch at Road A-7 in winter 1990 showed evidence of toxicity (NOEC $=60 \%$ ). It cannot be determined if this toxicity was due to naturally occurring conditions or to contamination associated with the F-Area seepline. However, no toxicity has been observed in Fourmile Branch below the F-or H-Area seeplines since 1990. This suggests that the seeplines were not toxic to Fourmile Branch.

\subsubsection{Toxicity Identification Evaluations}

In order to determine the cause of observed toxicity, Toxicity Identification Evaluations (TIE's) were performed on three representative seepline locations: (1) FSP-204, which is downgradient from the F-Area Seepage Basins, (2) HSP-103, which is downgradient from the H-Area Seepage Basins, and (3) UTR-029, which is uninfluenced by F-and H-Areas. In addition, as part of another study, a TIE was performed on water collected from Fourmile Branch at Road F, which is upstream from all SRS discharges.

F-Area Seepline Toxicity testing in September 1993 and June 1994 on seepline location FSP-204 demonstrated that the surface water was toxic. In November 1994 and July 1995, surface water from this location was analyzed for the presence of metals. Results indicated that potentially toxic concentrations of aluminum, cadmium, iron, lead, and zinc were present. In January 1995, a Phase I TIE was initiated. Although most treatments were ineffective in removing toxicity, adjusting the $\mathrm{pH}$ to 10 , aeration at $\mathrm{pH} 3$ and $\mathrm{pH} 6$, filtration, and filtration with a C-18 Solid Phase Extraction (SPE) column all reduced toxicity. The seep water was also 
TABLE 11. No Observed Effect Concentrations (NOECs) for Toxicity Testing Locations, 19901994 (Specht 1996).

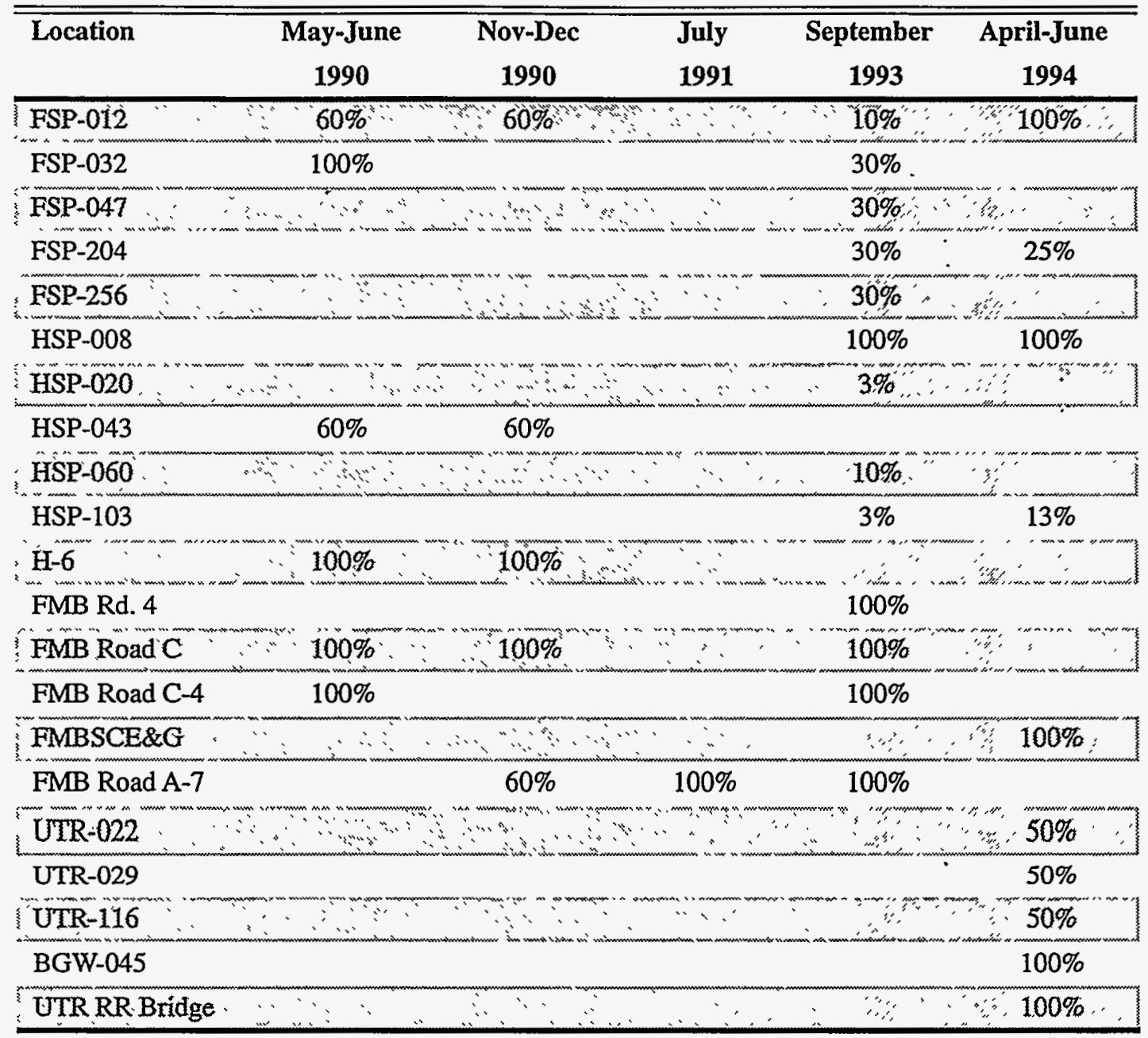

found to be less toxic at $\mathrm{pH} 8.5$ than at $\mathrm{pH}$ 6.0. EDTA chelation, which is effective in removing many cationic metals (including $\mathrm{Cd}, \mathrm{Cu}, \mathrm{Fe}, \mathrm{Pb}, \mathrm{Mn}$, and $\mathrm{Zn}$ was ineffective in reducing toxicity. Based on the results of the initial Phase I TIE studies, potential toxicants include the following: cationic metals not chelatable by EDTA, hydrogen sulfide, total dissolved solids, and non-polar organics (which are removed by a C-18 SPE column).

In March 1995, a methanol elution was performed to distinguish between the removal of non-polar organics (which can typically be eluted by methanol) and cationic metals. The results indicated that the toxicants were not eluted by the methanol, suggesting that the toxicity was not attributable to non-polar organics.

Additional Phase I testing was conducted in July 1995 to confirm the results of the January 1995 Phase I tests, and to evaluate alternative treatments. Based on the results, a volatile compound (hydrogen sulfide) and particulate contaminants were eliminated from further consideration. The anionic exchange resin failed to significantly reduce toxicity; the cationic resin, however, removed all of the toxicity. This implies that most of the toxicity was due to a cation. The graduated $\mathrm{pH}$ test indicated that the seep water was considerably less toxic at $\mathrm{pH} 8.0$ than at 6.5 , which would suggest one or more of the following toxicants: aluminum, copper, hydrogen sulfide or lead. Because copper and lead are chelatable by EDTA and EDTA did not reduce toxicity in the first round of Phase $I$ tests, the results suggest that cationic metals not chelatable by EDTA (probably 
aluminum) were the primary toxicants. However, some residual toxicity remained with most of the treatments that reduced toxicity. The presence of residual toxicity indicated that other toxicants, with different characteristics, also contributed to the toxicity.

H-Area Seepline Surface water collected from the H-Area seepline (HSP-103) in September 1993 and June 1994 was toxic to Ceriodaphnia dubia, with NOEC's of $3 \%$ and $12.5 \%$, respectively. In January 1995, a full TIE was initiated for this location. Aeration at $\mathrm{pH} 3$ was the only treatment that removed toxicity, suggesting that the toxicant was either volatilized or oxidized to a less toxic form at an acidic $\mathrm{pH}$. Therefore, potential toxicants include sulfide/hydrogen sulfide, and possibly cationic metals and/or acid volatile organics.

In May 1995, additional TIE tests that included aeration and nitrogen sparging were conducted on surface water collected from HSP-103. The only treatment that removed the toxicity was nitrogen sparging at the initial $\mathrm{pH}$; however, all of the aeration and sparging treatments reduced toxicity to some extent. These results suggest that the toxicant was a volatile compound. However, it is unlikely that hydrogen sulfide was the toxicant because its toxicity would be reduced more by aeration than by sparging. Because toxic concentrations of volatile organic compounds have not been found in the HSP seepline and because the toxicity was not removed by a C-18 SPE column, the toxicant is unlikely to be a volatile organic compound.

High concentrations of nitrate in the seepline water may be reduced to ammonia under anoxic conditions. Ammonia toxicity is $\mathrm{pH}$ and temperature dependent. Toxicity would be expected at approximately $2 \mathrm{mg} / \mathrm{L}$ under the $\mathrm{pH}$ and temperature conditions that were present at HSP-103. However, Chapell et al. (1995) did not report ammonia concentrations at $\mathrm{H}$-Area seeps that approached $2 \mathrm{mg} /$. No other source of volatile toxicants is known for the H-Area seepline.

Samples were collected twice from HSP-103 during the summer of 1995. However, neither sample was toxic when a baseline toxicity test was initiated prior to beginning additional TIE tests. Therefore, it was not possible to clearly identify the source of the toxicity at HSP-103. However, it appears that the source of the toxicity has been reduced or eliminated over time. In September 1993, the NOEC was 3\%, in June 1994, the NOEC was $12.5 \%$, in January 1995, when the TIE was initiated the NOEC was $60 \%$, and by the late summer 1995, the water was no longer toxic. These results suggest that the toxicity was due to constituents from the H-Area basins that have been reduced or eliminated by the capping of the basins.

Fourmile Branch In 1994, water samples from Fourmile Branch were used to culture Ceriodaphnia dubia as part of another investigation. Results indicated that water from Fourmile Branch was usually chronically toxic. Acute toxicity was also noted on an intermittent basis. To determine the cause of the toxicity, a TIE was initiated in June 1995 on water collected from Fourmile Branch at Road F. This location is near the headwaters of the stream and is upstream from all SRS discharges to the stream. Treatments that effectively reduced or removed toxicity were filtration, C-18 column, sodium thiosulfate addition at $1 \mathrm{mg} / \mathrm{l}$, and EDTA addition at $\geq 5 \mathrm{mg} / \mathrm{l}$. With the exception of filtration at neutral $\mathrm{pH}$, all treatments were effective in removing cationic metals. Therefore, the toxicity in Fourmile Branch was probably attributable to a metal.

Phase II TIE studies were initiated in July 1995 to identify and confirm the source of toxicity in Fourmile Branch. The results of the Phase II investigations confirmed that the untreated sample was toxic and that adjustment to $\mathrm{pH} 9.0$ and filtration removed the toxicity. When iron was spiked back into the sample at concentrations exceeding $2 \mathrm{mg} / \mathrm{l}$, toxicity was again observed. These results confirmed that iron was the source of the toxicity in water collected from Fourmile Branch. Because the sample was collected upstream from all SRS discharges to the stream, it appeared that the toxicity was due to naturally occurring iron. The iron was probably leached from surrounding soil by the low $\mathrm{pH}$ resulting from naturally occurring humic and fulvic acids that are characteristic of blackwater streams.

\section{Background Seepline}

In April 1993, background seepline location UTR-029 was sampled and analyzed for organic and inorganic constituents (Dixon and Cummins 1994). Analytical results indicated elevated levels of total aluminum (5.93 
$\mathrm{mg} / \mathrm{L}$ ), iron (17.7 $\mathrm{mg} / \mathrm{L})$, manganese ( $1.9 \mathrm{mg} / \mathrm{L})$, zinc ( $32.5 \mathrm{mg} / \mathrm{L})$ and total suspended solids ( $308 \mathrm{mg} / \mathrm{L})$, and a moderately high hardness $(59 \mathrm{mg} / \mathrm{L})$. No organic compounds were detected at levels above background concentrations. In April 1994, a chronic toxicity test for this location indicated that it was acutely toxic to Ceriodaphnia dubia.

A partial Phase I TIE was conducted in November 1994 to determine if the toxicity was caused by a metal or metals. Four treatments known to be effective in removing toxicity were used.Each test, except the graduated $\mathrm{pH}$ test, was effective at removing chronic toxicity. These results were consistent with the responses that would be expected if the toxicant were a metal. The orange precipitate that resulted when the $\mathrm{pH}$ was adjusted to 10 and filtered suggests that the toxicity was due to iron.

Following the Phase I partial TIE for cationic metals, Phase II TIE studies were initiated on a water sample collected from UTR-029 on January 5, 1995 (ETT 1995). In the Phase II studies, water from the seep was adjusted to $\mathrm{pH} 10$ and filtered to remove cationic metals. Samples of the treated water where then spiked with iron $(2.1 \mathrm{mg} / \mathrm{L})$, with zinc $(17 \mathrm{mg} / \mathrm{L})$, and with iron $(2.1 \mathrm{mg} / \mathrm{L})$, zinc $(17 \mathrm{mg} / \mathrm{L})$ and manganese $(0.71 \mathrm{mg} / \mathrm{L})$. These spiked samples were then subjected to the same treatments that removed toxicity in the Phase I tests (filtration at $\mathrm{pH} 10$, sodium thiosulfate addition, and EDTA chelation).

The results indicated that $2.1 \mathrm{mg} / \mathrm{L}$ of iron produces a chronic toxic effect of similar magnitude to that observed in the seep sample (Table 11). The addition of zinc to a concentration of $17 \mathrm{mg} / \mathrm{L}$ did not increase the toxicity, which suggests that the amount of zinc present in the UTR-029 seep water was not great enough to produce toxicity. Similarly, the addition of manganese and zinc to the sample that had been spiked with iron did not increase the toxicity. The results of the Phase II TIE therefore confirmed that the observed toxicity of UTR-029 was due to iron. Because this background location has not been impacted by SRS operations, it is concluded that the iron is naturally occurring, and has probably been leached from the soil because of the relatively low $\mathrm{pH}$ (5.49) of the groundwater. 


\subsection{Constituients of Interest}

One of the principal tasks associated with site characterization and risk assessment is to identify analytes, chemical compounds, and radioisotopes that have the potential to cause adverse effects on human health and the environment. This is typically achieved using a screening protocol tailored to the existing data, affected media, availability of benchmark values, and other factors. When performed as part of a baseline risk assessment, constituents that are potentially unit-related and are present at concentrations that may impact human health and the environment are referred to as constituents of potential concern (COPCs). COPCs are generally identified as part of a data screening process involving validation, statistical analyses, and other investigative procedures. Because this report seeks to identify constituents from several investigations that have used different screening protocols, constituents are broadly categorized herein as "constituents of interest." These include constituents that meet the following criteria: (1) they were identified as a COPC in a screening level risk assessment (WSRC 1995d) for the F- and H-Area groundwater unit, (2) they were identified as being of concern by an independent peer review (Babich et al. 1995), or (3) concentrations exceeded a regulatory threshold value such as the primary and secondary drinking water standards, EPA Region III risk-based concentrations (EPA 1997), or an ecological screening value issued by EPA Region IV (EPA 1995). Constituents of interest for human health and ecological are listed in Tables 12 and 13, respectively.

\subsection{Human Health}

Constituents of interest in water pertaining to human health varied by screening protocol (Babich et al. 1995, Dixon and Rogers 1993 b,c; 1994 a, EPA 1997,WSRC 1995d,) and included radiological and non-radiological categories (Table 12). The independent site peer review (Babich et al. 1995) identified cadmium, mercury, nitrate and nitrite as non-radiological constituents of interest. Radium-228, strontium-90, technetium-99, and tritium were listed as radiological constituents of interest (Babich et al. 1995). The human health component of the screening level risk assessment (WSRC 1995d) considered two risk scenarios: (1) a current worker who sampled groundwater monitoring wells, and (2) a hypothetical, future on-site resident. For a current worker in F-Area, risk from exposure to chemicals was below the 1.0E-06 threshold of concern whereas risk from radionuclides marginally exceeded the threshold. For a current worker in H-Area, risk from chemicals and radionuclides was below the $1.0 \mathrm{E}-06$ threshold level.

For a hypothetical, future on-site resident who drank water contaminated with tritium from Fourmile Branch, a cancer risk ( $P>1.0 \mathrm{E}-04$ ) would result. Once this water reached the Savannah River, risk marginally exceeded the 1.0E-06 threshold level. A hypothetical future on-site resident who consumed water from a well would be at risk from chemicals and radionuclides in F-Area. In H-Area, risk from chemicals was above the threshold level whereas risk from radionuclides was below the theshold level.

Based on the two risk scenarios, the screening level risk assessment identified seven non-radiological constituents of interest to human health. Non-radiological constituents of interest that were identified for human health included aluminum, beryllium, cadmium, manganese, mercury, nitrite, and nitrate. Eight radiological constituents of interest were identified (Table 12).Eleven additional constituents had concentrations that exceeded primary or secondary drinking water standards, maximum contaminant levels, or risk-based concentrations (Table 12). Cadmium, nitrate, and radium-228 were the only constituents of interest to human health that were identified by all three screening protocols.

\subsection{Ecological}

Ecological constituents of interest were identified for both sediment and surface water (Table 13). Based on a comparison of the 1995 analytical results (WSRC 1995b) with EPA Region IV screening levels (EPA 1995), eleven non-radiological constituents of interest were identified in sediment. Ten constituents in sediment at the seeplines had 95\% upper confidence intervals that exceeded ecological screening values (Table 13). These included antimony, arsenic, cadmium, chromium, copper, iron, lead, mercury, nickel, and silver. The concentration of zinc in the sediment of Fourmile Branch exceeded the ecological screening value but the seepline sediments did not. Concentrations of arsenic, chromium, and silver exceeded EPA sediment screening values, but were not identified as constituents of interest in surface water. 
copper, iron, lead, and mercury. Although not identified as COPCs, both $\mathrm{pH}$ and specific electrical conductance influence the distribution and availability of constituents and therefore should be monitored. Other constituents whose concentrations exceeded EPA Region IV screening values included antimony, arsenic, beryllium, chromium, copper, silver, and thallium. Cyanide, nitrate, and 14 metals represent the constituents of interest based on the various screening protocols (Table 13).

TABLE 13. Ecological constituents of interest in sediment and surface water.

\begin{tabular}{l}
\hline Constituent of Interest \\
\hline Aluminum Sediment
\end{tabular}




\subsection{Remedial Action}

\subsection{General Description}

The objective of the remedial action is to reduce the concentration of contaminants in groundwater to levels that comply with the standards identified in the RCRA post-closure permit. Contaminated groundwater will be extracted, treated, and injected hydraulically upgradient from the extraction point. The treatment system will reduce heavy metals, nitrates and some radionuclides to groundwater protection standards. To adequately provide hydraulic control of the contaminated groundwater plumes beneath and downgradient of the seepage basins, the project components will be designed for the extraction, treatment, and injection of affected groundwater at an optimum flow rate, plus $15 \%$ contingency, of approximately $410 \mathrm{gpm}$ total from both areas. Each area ( $\mathrm{F}$ and $\mathrm{H}$ Seepage Basins Areas) will have its own independent modular remediation system. The major components for each remediation system will include: (1) groundwater extraction and collection system, (2) modular groundwater and secondary waste treatment system, (3) treated water distribution and injection system, and (4) secondary waste collection and packaging system. Each component will be equipped with all the necessary accessories required for flow control, treatment, and safety alarms. This will allow the processes for both $\mathrm{F}$-and $\mathrm{H}$-Areas to be monitored and controlled.

The Groundwater Extraction and Collection System will provide adequate hydraulic control of the contaminated groundwater plumes delineated by the $10,000 \mathrm{pCi} / \mathrm{ml}$ tritium and the $2 \mu \mathrm{g} / \mathrm{L}$ mercury isoconcentration contours. This action will prevent these plumes from reaching and/or further discharging to Fourmile Branch. The contours are based on the second quarter 1992 groundwater monitoring data, the most current and complete at the start of the project. The extraction and collection system will allow flexibility in its operation for pumping rates to be adjusted over a fixed range. Each extraction well (Figures 18 and 19) will be equipped with a submersible pump and a control valve to regulate flow so it can be placed in or out of service as required. Wells will have ports connected to a water collection system at the ground surface for sampling. The collection system in each area will transport the groundwater from the well to the mixing tank(s) in each area.

The Modular Groundwater Treatment System will meet the requirements of both the Industrial Wastewater Treatment (IWT) permit for above ground water treatment and the Underground Injection Control (UIC) permit for the injection of the treated water. The modular treatment facilities will remediate the extracted groundwater by a surface treatment system (1) to meet the regulatory criteria for the Phase I treatment standards specified in the RCRA post-closure permit for the concentrations of the contaminants of concern, and (2) to meet engineering criteria for physical, chemical, and biological characteristics, making the water suitable for injection. Tritium and nitrate removal is not included in the Phase I treatment process. The modular treatment facilities will consist of process equipment only. At the location of the modular equipment, storm water accumulation will be minimized with rain covers, and spills will be confined with concrete pads with curbing.

The Treated Water Distribution and Injection System will transfer the treated water through an injectate tank(s) and piping network to the injection wells. The treated water will be injected hydraulically upgradient into the aquifers from which it was extracted. The injection wells will probably be fully penetrating and fully screened in the appropriate aquifer. Each well will have a valve so any individual injection well can be placed in or out of service or have its flow rate adjusted without impacting other injection wells.

The Secondary Waste Collection and Packaging System will prepare the secondary waste generated by the treatment processes for disposal in the E-Area Solid Waste Disposal Facility (SWDF), if as expected the waste is classified as low-level radioactive waste.

The proposed remedial action will utilize a reverse osmosis design combined with pre-filtration and secondary waste stream treatment using coagulation, precipitation and encapsulation to achieve acceptable TCLP (Toxicity Characteristic Leachate Procedure) results for the filter cake. The resultant liquid stream will be polished and combined with the reverse osmosis permeate into the effluent stream. The individual unit processes include: (1) sand filtration, (2) reverse osmosis, (3) chemical treatment precipitation, (4) clarification, (5) sludge dewatering and drying, and (6) effluent polishing. 


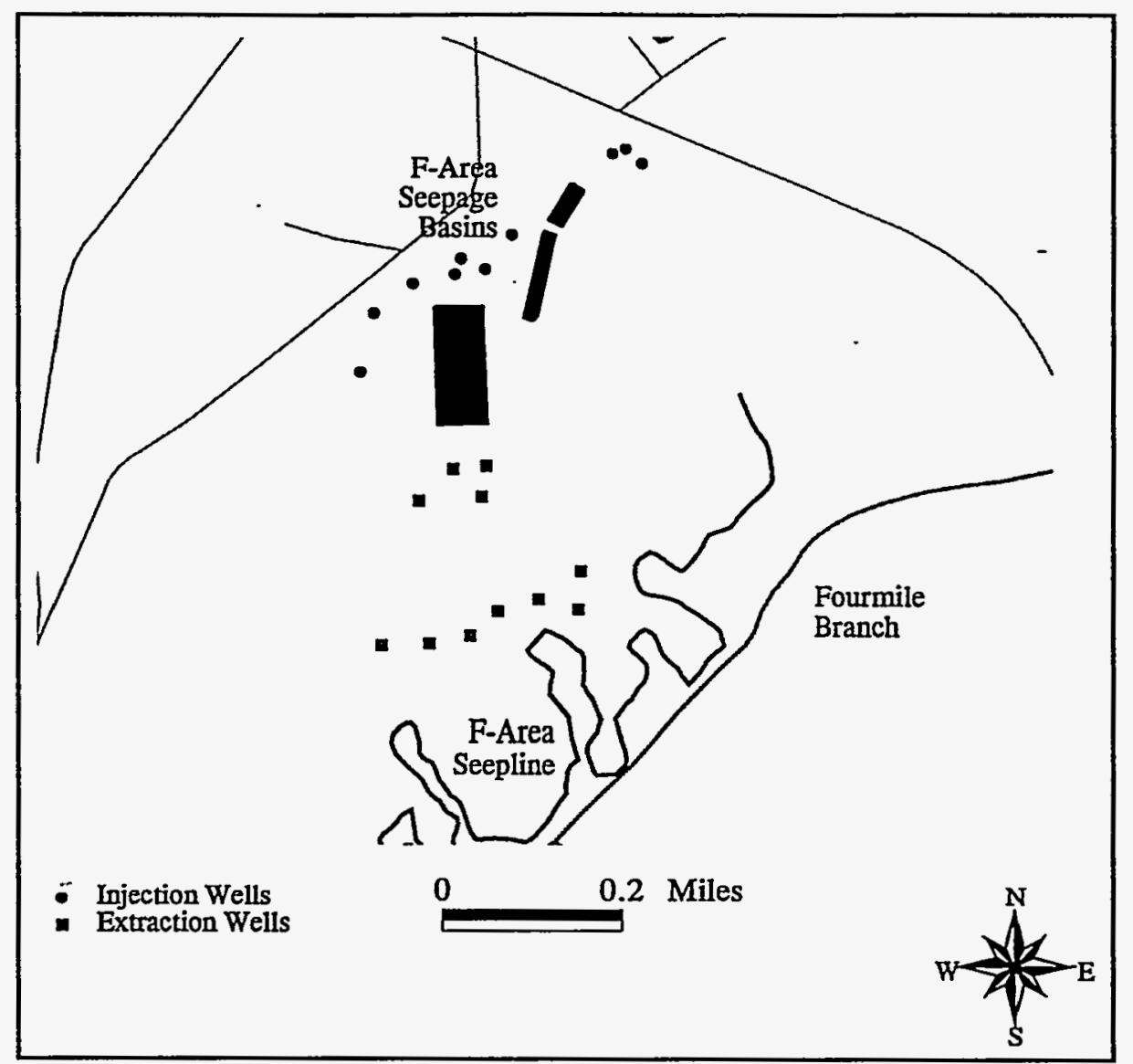

FIGURE 18. Distribution of extraction and injection wells for F-Area.

\subsection{Potential Environmental Effects}

Potential environmental effects associated with the proposed remedial action are considered to be temporary. The pumping of water from the aquifer could produce cones of depression within the wetlands. Although localized and relatively small, the lowering of the water table could affect soil moisture. Changes in soil moisture could be detrimental to wetland flora which in turn could affect vegetative structure and wildlife habitat. Until vegetation can become re-established, surface water runoff could foster soil erosion and siltation of Fourmile Branch. When the pump and treat remedial action is completed, however, the process of natural succession should revegetate these areas.

\subsection{Evaluating the Remedial Action}

One of the basic questions associated with any remedial action is "how does one determine when the remedial action goal has been achieved?" To answer this, some measure of performance must be identified and monitored. One approach is the use of control charts (Gilbert 1987). Control charts are widely used in industry and research and development laboratories to evaluate performance and specification compliance. From the population distribution of a given parameter, such as the concentration of a metal in surface or groundwater, repeated samples are taken over time. Means or individual values are then plotted against an upper and lower predetermined limits. If data points fall outside the boundaries, the process is declared to be "out of control". Otherwise the process is declared to be "within control". The advantage of control charts or modifications thereof is that they are fairly easy to construct and they provide a quick visual evaluation of performance. 


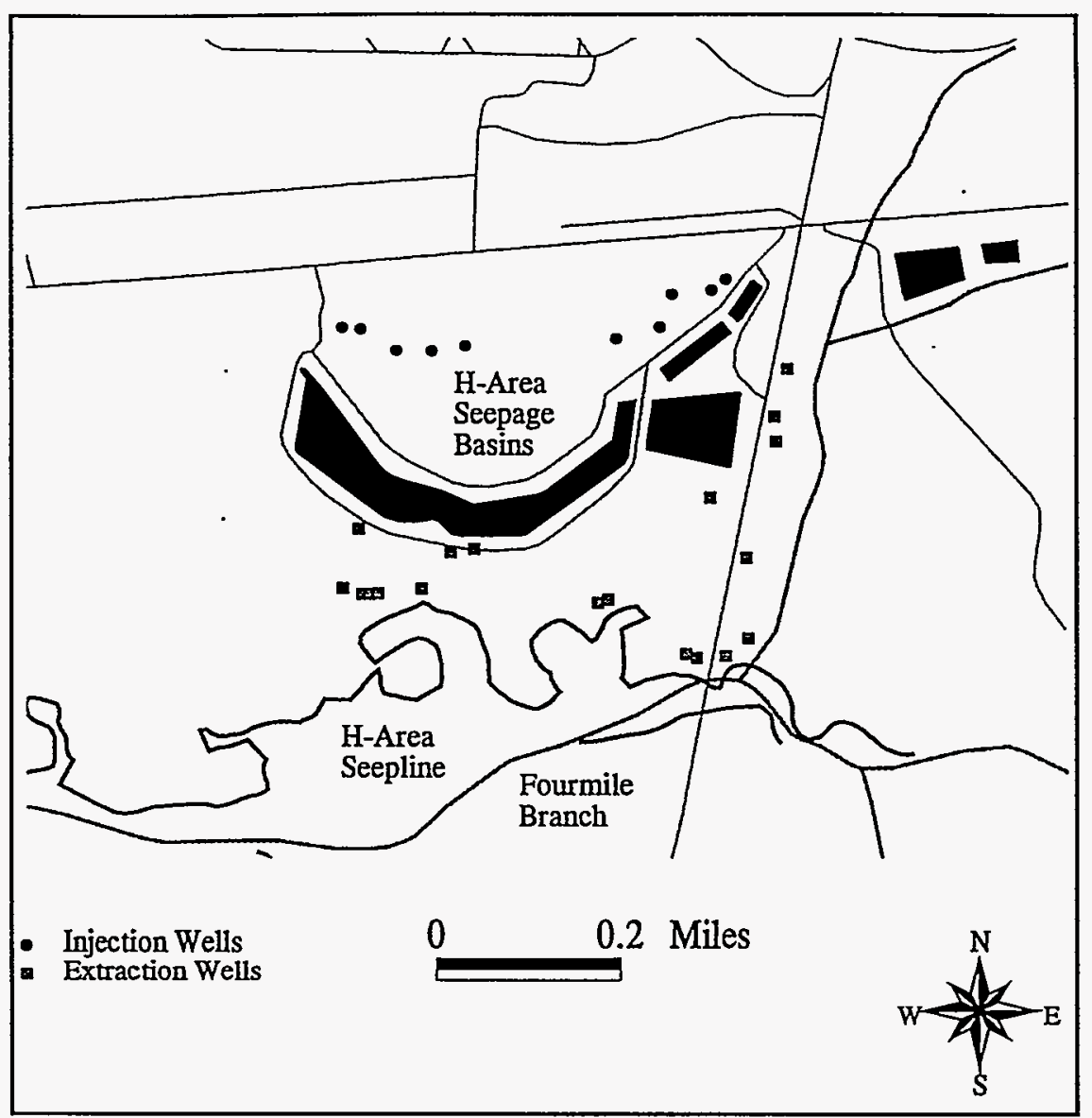

FIGURE 19. Distribution of extraction and injection wells for $\mathbf{H}$-Area.

There are two standards or criteria against which comparisons can be made-background and regulatory compliance benchmarks. For a constituent of interest within a matrix, control charts using background data would require an estimate of the pre-operational arithmetic mean and standard deviation. Individual values are then plotted against the operating background level (mean plus standard deviation) and an action level (operating background level plus 1.5 times the standard deviation). Control charts can also be simplified to using regulatory compliance benchmarks as control limits. For example, chronic ambient water quality criteria and primary drinking water standards could be established as the limits of control. Values such as individual observations, means, or $95 \%$ upper confidence intervals could be plotted against these to determine environmental compliance or lack thereof. An example of a control chart using individual tritium values is shown in Figure 20.

Parametric and non-parametric statistical analyses can also be used to detect significant differences in concentrations between populations (e.g. years). One-tailed tests are appropriate when the direction (i.e., greater than or less than) is important. It should be noted, however, that each of the approaches discussed above must be applied individually by matrix to the constituents of interest. Although the use of these methods can serve as a performance measurement for abiotic data, other approaches must be used for evaluating terrestrial and aquatic ecosystems. In the vicinity of the FHSB, the majority of existing ecological data is associated with Fourmile Branch and its wetlands. Gauging the effectiveness of remedial action could be attained by monitoring the floristic diversity and revegetation of stressed areas within the wetlands and also by continued monitoring of fishes and macroinvertebrates in Fourmile Branch. Color infrared aerial imagery could be used detect significant changes in the arboreal canopy of the wetlands. Sampling and analyses would be required, however, in Fourmile Branch. 


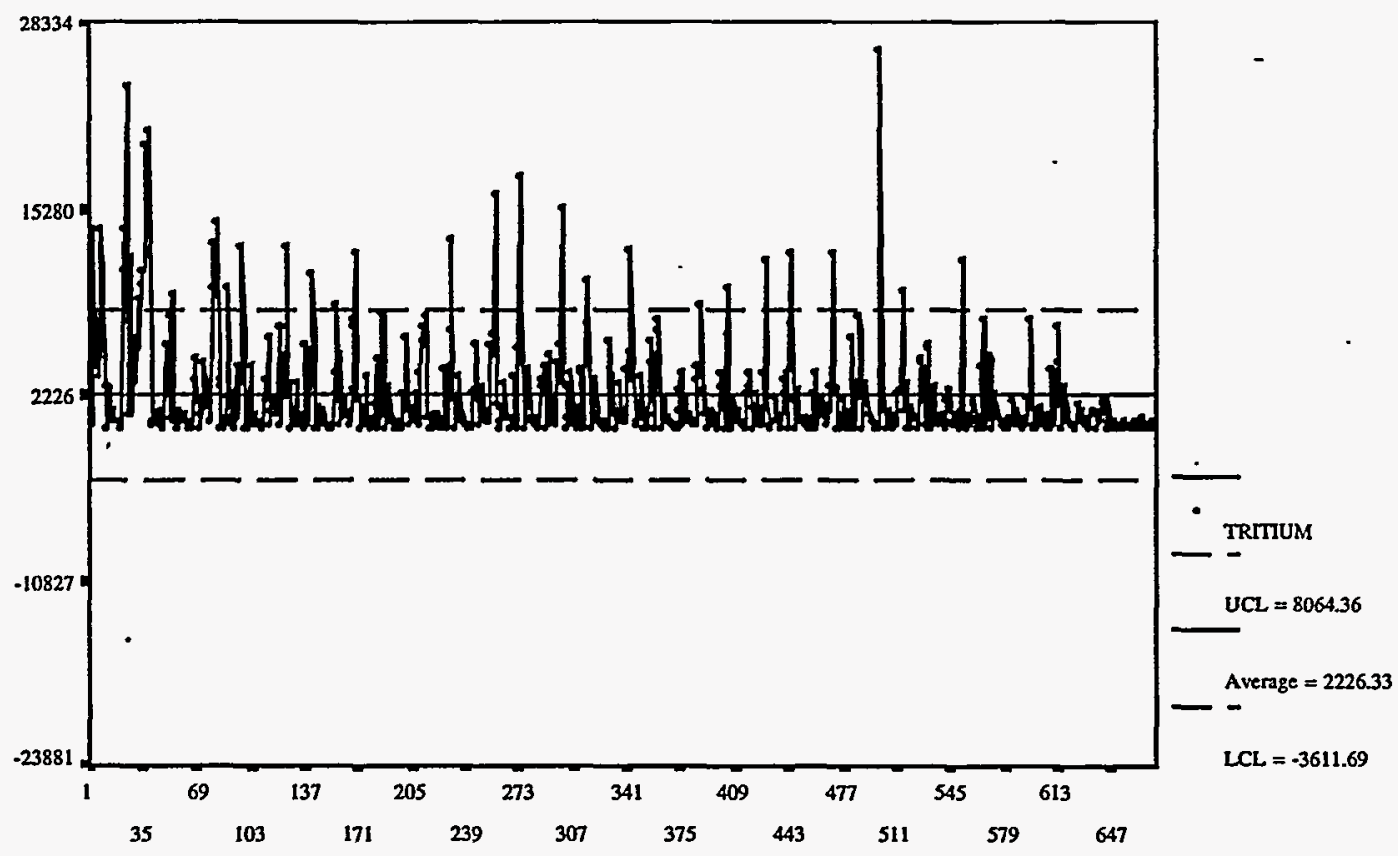

FIGURE 20. Example of a control chart for tritium (pCi/mL). 


\subsection{Summary and Conclusions}

From 1955 until 1988, the F-and $\mathrm{H}$-Area facilities annually discharged approximately 80 million gallons of wastewater into seven, unlined seepage basins. The wastewater, which contained radioactive and non-radioactive constituents, seeped into the underlying soil and groundwater, eventually reaching Fourmile Branch and the Savannah River. Environmental monitoring studies have detected concentrations that pose potential risk to human health and the environment. In 1991, the basins were certified closed by the South Carolina Department of Health and Environmental Control. The RCRA Part B permit required a corrective action plan to remediate contaminated groundwater.

Since the basins were closed, numerous investigations have been conducted to better understand the baseline environment, monitor concentrations and radioactivity of constituents, evaluate the mobility and transfer of contaminants, and to identify a remedial action that can reduce or eliminate contaminants. The objectives of this report are to summarize the results of these investigations, identify constituents of interest, describe the remedial action and its potential effects, and identify an approach that can evaluate the effectiveness of the remedial action.

\subsection{Baseline Environment}

Environmental studies in the vicinity of the F-and H-Area seepage basins have included both abiotic and biotic components. Several investigators have examined surficial soils on the SRS but the number of samples was small and sample locations were not specific to the FHSB. The most recent and comprehensive study of soils was done in 1995 at the F-and H-Area facilities as part of the site-wide monitoring program. Mean radioactivity of Cs-137, Pu-238, and Pu-239 were higher than the two control sites 100 miles away. The mean activity of strontium, however, was higher at the control sites than the FHSB. Relatively little information is available for non-radiological constituents in surficial soils in the vicinity of the FHSB.

Preliminary investigations of sediment identified elevated concentrations of metals and radionuclides. The most extensive examination of sediments was conducted during 1995 in both seepline areas. The majority of non-radiological constituents in sediment had $95 \%$ upper confidence intervals that exceeded background and ecological screening values. There are no human health screening values for sediment. Radioisotopes that exceeded background levels included Cs-137, Ni-63, Ra-226, Th-232, and others. Radioactivity of tritium in sediment was markedly above background level $(38 \mathrm{pCi} / \mathrm{g})$, ranging from $3833 \mathrm{pCi} / \mathrm{g}$ at the $\mathrm{F}$-Area seepline to $616 \mathrm{pCi} / \mathrm{g}$ in Fourmile Branch. Because the analytical data for sediment is limited to a single year, it was not possible to identify trends.

In the 1990 's, three programs were initiated to investigate surface water chemistry in the vicinity of the F-and H-Areas: (1) semi-annual sampling of the F-and H-Area seeplines and Fourmile Branch, (2) quarterly tritium surveys of both seeplines, and (3) quarterly sampling of the old F-Area effluent ditch. From 1992 to 1997, surface water at the seeplines and Fourmile Branch were analyzed for metals, organic compounds, radionuclides, and other variables. The concentrations of several metals and radioisotopes exceed background, human health, and ecological threshold values. These are identified below as constituents of interest.

From 1994 to 1996, surface water samples were also collected along the old F-Area ditch and analyzed for tritium and volatile organic compounds. Concentrations of tritium, tetrachloroethylene, trichloroethylene, dichloroethylene, and vinyl chloride exceeded primary drinking water standards or maximum contaminant levels. Vinyl chloride, a common laboratory chemical, is not considered a constituent of interest. Studies along the old F-Area effluent ditch indicated that two different groundwater flow paths existed. These studies have also confirmed that tritium and volatile organic compounds, presumably from the old burial ground, have migrated to the wetlands along the effluent ditch.

Surveys of tritium in surface water have been conducted since 1989. In 1992, a sampling program was begun at both seeplines and Fourmile Branch. Since the initial survey, the mean radioactivity of tritium has declined 
annually at each location. Prior to 1995 , mean levels of tritium were highest at the H-Area seepline, ranging between 8402 and $2667 \mathrm{pCi} / \mathrm{mL}$. In 1995 and 1996, however, tritium radioactivity was higher at the F-Area seepline than the H-Area seepline. Tritium radioactivity in Fourmile Branch has consistently been the lowest of the three locations, and has also declined annually since 1992 . The grand means $(1989,1992-996)$ of tritium at the F-Area and H-Area seeplines were 1992 and $3186 \mathrm{pCi} / \mathrm{mL}$, respectively. The grand mean of tritium in Fourmile Branch (1992 to 1996) was $333 \mathrm{pCi} / \mathrm{mL}$. The maximum concentration level for tritium is $20 \mathrm{pCi} / \mathrm{mL}$.

The median $\mathrm{pH}$ in seepline surface water was lowest at the F-Area, intermediate at H-Area, and highest in Fourmile Branch. Seepline $\mathrm{pH}$ values may be associated with past operations. of the basins. The mean specific electrical conductance, which was two times higher in F-Area than H-Area from 1989 to 1996 , was used to differentiate plumes in the burial ground from FHSB. Studies have also shown an association between tritium and conductivity at both seeplines.

Vegetation studies in the vicinity of the $\mathrm{F}$-and $\mathrm{H}$-Areas has included wetiand mapping and characterization efforts, revegetation assessment, and seed germination studies. Jurisdictional wetlands have been identified and mapped between Fourmile Branch and the F-and H-Areas. Canopy mortality covering approximately eight acres in the wetlands has resulted from toxicants associated with the seepage basins. Natural revegetation of these areas has been poor. The survival of planted tupelo seedlings has also been marginal, declining annually from 1994 to 1996. Seed germination studies have shown that wetland soils are not optimal for plants, generally reducing seed vigor. These studies also showed that toxicity was reduced with a series of soil washings, indicating that natural water transport of soluble contaminants had occurred. This implies that soil toxicity could be reduced naturally over time as contaminants are removed by leaching and surface runoff.

Faunal studies in the vicinity of the FHSB have included macroinvertebrates, fish, herpetofauna, and small mammals. Macroinvertebrates inhabiting Fourmile Branch in the 1980's were reported to be similar to those found in other SRS streams. In 1994, however, Fourmile Branch near Road C was found to be perturbed compared to other SRS streams. Low dissolved oxygen, rather than discharges from the FHSB, was identified as the causal factor. Species richness of fish in Fourmile Branch was found to be similar to other SRS streams. Nonthermal reaches of Fourmile Branch do not appear to have been impacted by effluent discharges. Preliminary studies of fish tissue, however, revealed the presence of several metals but it is not clear where the points of exposure occurred. Comprehensive studies of fish in Fourmile Branch are planned for 1997. These will provide a better understanding of community structure and the effects of ecological stressors.

Chronic aquatic toxicity testing was conducted beginning in 1990 at both seeplines, Fourmile Branch, and at control sites. Surface water at the seeplines was toxic at nine of eleven locations; control sites were slightly toxic. Toxicity at the seeplines varied temporally, and was perhaps associated with precipitation which can dilute the concentration of the toxicant. Toxicity has not been observed in Fourmile Branch since 1990, suggesting that the seeplines do not affect the stream's water chemistry. To identify the specific toxicant, toxicity identification evaluations were conducted. At the F-Area seepline, aluminum and cadmium were identified as the primary toxicants. Residual toxicity, however, indicated that other toxicants, possibly iron, also contributed to the observed toxicity. Toxicity identification evaluations at the $\mathrm{H}$-Area seepline were inconclusive, but the results suggested the presence of a volatile organic compound. It furthermore appeared that some toxicants associated with the $\mathrm{H}$-Area seepage basin have been reduced or eliminated by the capping of the basins. Toxicity at controls sites and Fourmile Branch were due to naturally occurring iron.

\subsection{Constituents of Interest}

Constituents of interest that pose potential risk to human health and the environment were identified from three screening protocols. These included a screening level risk assessment, an independent peer review, and comparisons to regulatory threshold values. For a hypothetical, future on-site resident who drinks water from Fourmile Branch, a cancer risk( $\mathrm{P}>1.0 \mathrm{E}-04)$ would result from tritium.In the Savannah River, however, risk marginally exceeds the $1.0 \mathrm{E}-06$ threshold level. Other radioisotopes of interest include radium, strontium, and technetium. Non-radiological constituents of interest to human health included beryllium, cadmium, lead, 
manganese, mercury, nitrite, and nitrate.

Ecological constituents of interest in surface water included the metals aluminum, beryllium, cadmium, chromium, copper, iron, lead, mercury, selenium, silver, thallium, and zinc. No radiological constituents of interest were identified. Constituents of interest in sediment were arsenic, cadmium, chromium, copper, iron, lead, mercury, nickel, and silver.

\subsection{Remedial Action}

The remedial action that is proposed for the F-and $\mathrm{H}$-Areas consists of a pump-and-treat technology that utilizes reverse osmosis. Under this scenario, a series of extraction wells would pump contaminated groundwater to the surface for treatment. The treatment system will reduce heavy metals, nitrates, and some radionuclides to groundwater protection standards. Although tritium cannot be removed by this approach, the well system is designed to control seepage into the wetlands by the groundwater. The treated water, which would retain radioactive tritium, would be reinjected into the aquifer until the tritium decays naturally to acceptable levels. Potential effects associated with this remedial action include alteration of wetland and aquatic habitat. Zones of depression from pumping could reduce soil moisture to levels that no longer support wetland flora. In turn, wildlife habitat could be adversely impacted. These affects would be short-term; cessation of pumping would permit the re-establishment of wetland flora within a few years. Positive affects associated with the remedial action would be a reduction of toxicant concentrations. Continued monitoring of sediment and surface water chemistry, particularly constituents of interest, combined with the use of control charts can be used to evaluate the effectiveness of the remedial action. 


\subsection{References}

Aho, J.M., C.S. Anderson, K.B. Floyd, and M.T. Negus. 1986. Patterns of Fish Assemblage Structure and Dynamics in Waters of the Savannah River Plant, Comprehensive Cooling Water Study Final Report SREL27, Savannah River Ecology laboratory, Aiken, SC.

Babich, A., M.M. Benjamin, J.D. Bredehoeft, W.E. Cooper, G.L. Culp, R.D. Kimbrough, J.W. Massmann, and S.E. Parent. October 19, 1995. Independent Scientific Peer Review of Groundwater Remediation Technologies-Evaluation of Proposed Groundwater Corrective Actions F- and H-Area Seepage Basins Savannah River Site. ISPR Final Report.

Chappell, R.W., F.P. Winslow, K.Y. McCluskey, K.L. Dixon, J.W. Koch, and V.A. Rogers. 1996. Semi-Annual Sampling of Fourmile Branch and Its Seeplines in the F and H Areas of SRS: February 1993, July 1993, and April 1994. Westinghouse Savannah River Company, WSRC-TR-94-0454.

Cummins, C.L. and K. L. Dixon. 1995. Quarterly Sampling of the Wetlands Along the Old F-Area Effluent Ditch: November 1994. Westinghouse Savannah River Company, WSRC-TR-95-0117.

Cummins, C.L. and K.L. Dixon. 1994. Quarterly Sampling of the Wetlands Along the Old F-Area Effluent Ditch: August 1994. Westinghouse Savannah River Company, WSRC-TR-94-0543, Rev 1.

Dames and Moore, Inc. 1991. Vegetation Survey of Pen Branch and Four Mile Creek. Westinghouse Savannah River Company, WSRC-RP-92-482.

Dixon, K.L. September 1996a. Sampling of the Wetlands Along the Old F-Area Effluent Ditch: September 1995 and March 1996. Westinghouse Savannah River Company, WSRC-TR-96-0288.

Dixon, K.L. September 1996b. Monitoring of the Water Levels in the Wetlands of Fourmile Branch Near the F and H-Areas of SRS. Westinghouse Savannah River Company, WSRC-TR-96-0289.

Dixon, K.L. 1994. Sampling and Analysis of Soil from the Old F-Area Effluent Ditch and its Surrounding Wetlands. Westinghouse Savannah River Company, WSRC-TR-94-0311.

Dixon, K.L. and C.L. Cummins. 1994. Quarterly Sampling of Wetlands Along the Old F-Area Effluent Ditch: May 1994. Westinghouse Savannah River Company, WSRC-TR-94-0365, Rev 1.

Dixon, K.L. and V.A. Rogers. 1994a. Semi-Annual Sampling of Fourmile Branch and Its Seeplines in the F and H Areas of SRS: July 1992. Westinghouse Savannah River Company, WSRC-TR-93-289, Rev-0.

Dixon, K.L. and V.A. Rogers. 1994b. Results of the Quarterly Tritium Survey of the Four Mile Creek and its Seeplines in the F- and H-Areas of SRS: June 1993. Westinghouse Savannah River Company, WSRC-TR93-656 Rev 0.

Dixon, K.L. and V.A. Rogers. 1993a. Results of the Fourth Quarter Tritium Survey of the F-and H-Area Seeplines: March 1993. Westinghouse Savannah River Company, WSRC-TR-93-526, Rev 0.

Dixon, K.L. and V.A. Rogers. 1993b. Semi-Annual Sampling of Fourmile Branch and Its Seeplines in the F and $H$ Areas of SRS. Westinghouse Savannah River Company, WSRC-TR-93-293.

Dixon, K.L. and V.A. Rogers. 1993c. Semi-annual Sampling of Fourmile Branch and Its Seeplines in the Fand H-Areas of SRS: July 1992. WSRC-TR-93-289, Westinghouse Savannah River Company, Savannah River Technology Center, Aiken, SC. 
Dixon, K.L. and V.A. Rogers. 1993d. Results of the Third Quarter Tritium Survey of the F- and H-Area Seeplines: December 1992. Westinghouse Savannah River Company, WSRC-TR-93-284, Rev 1.

Dixon, K.L. and V.A. Rogers. 1993e. Results of the Second Quarter Tritium Survey of the F- and H-Area Seeplines: September 1992. Westinghouse Savannah River Company, WSRC-TR-93-129.

Dixon K.L. and V.A. Rogers. 1992. Results of the First Quarter Tritium Survey of the F- and H-Area Seeplines: May 1992. Westinghouse Savannah River Company, WSRC-TR-92-304.

Dixon, K.L., C.L. Cummins, and V.A. Rogers. 1994a. Quarterly Sampling of the Wetlands Along the Old FArea Effluent Ditch: March 1994. Westinghouse Savannah River Company, WSRC-TR-94-0225.

Dixon, K.L., V.A. Rogers, and B.B. Looney. 1994b. Results of the Quarterly Tritium Survey of Fourmile Branch and its Seeplines in the F- and H-Areas of SRS: September 1993. Westinghouse Savannah River Company, WSRC-TR-94-0286, Rev 1.

Dixon, K.L., V.A. Rogers, and B.B. Looney. 1993. Results ofthe Quarterly Tritium Survey of Four Mile Creek and its seeplines in the F- and H-Areas of SRS: September 1993. Westinghouse Savannah River Company, WSRC-TR-93-286-ESS, Rev. 1, Aiken, SC.

Dunn, D.L. and K.L. Dixon. 1996. Sampling of the Wetlands Along the Old F-Area Effluent Ditch: October 1996. Westinghouse Savannah River Company, WSRC-TR-97-0050.

Eaton, D., and C.E. Murphy. 1993. Toxicity Test of the F-Area Seep Soils by Laboratory Lettuce Seed Germination and Seedling Growth. Westinghouse Savannah River Company, WSRC-TR-93-669.

E.I. du Pont de Nemours and Co. 1988. U.S. Department of Energy, Savannah River Plant Environmental Report for 1987. DPSPU-88-30-1.

ETT Environmental, Inc. 1995. Chronic Toxicity Identification Evaluation Phase II, UTR-029 Seep at the Savannah River Site, January 1995. ETT Environmental, Greenville, SC 29606.

Firth, P., J.R. O'Hop, B. Coler, and R.A. Green. 1986. Lotic aquatic ecosystems of the Savannah River Plant: Impact evaluation, habitat analyses, and the lower food chain communities, Vol. I. E.I. du Pont de Nemours and Co., DPST-86-797.

Friday, G.P, G.D. Hartman, H.E. Mackey, R.S. Riley, J.L. Roach, W.L. Specht, H.M. Westbury, and L.D. Wike. 1994. A Summary of Ecological Investigations at the Burial Ground Complex, Savannah River Site 1994. Westinghouse Savannah River Site, WSRC-RP-94-1221.

Gilbert, R.O. 1987. Statistical Methods for Environmental Pollution Monitoring. Van Nostrand Reinhold, New York.

Gladden, J., 1988. Evaluation of Stream Biological Communities in Nonthermal Reaches of Four Mile Creek. E.I. du Pont de Nemours and Company, Savannah River Laboratory, DPST-88-324.

Greenwood, K.P., M.E. Hane, A.J. Lander, C. Loehle, and C.J. Richardson. 1990. Assessment of Tree Toxicity Near the F- and H-Area Seepage Basins of the Savannah River Site. Westinghouse Savannah River Company, WSRC-TR-90-253.

Haselow, J.S. 1990. Analysis of Stream Bed Sediments of Four Mile Creek. Westinghouse Savannah River Company, WSRC-RP-90-0812. 
Haselow, J.S., M. Harris, B.B. Looney, N.V. Halverson, and J.B. Gladden. 1990. Analysis of Soil and Water at the Four Mile Creek Seepline Near the F and H Areas of SRS. Westinghouse Savannah River Company, WSRC-RP-90-0591.

Hem, John D. 1989. Study and Interpretation of the Chemical Characteristics of Natural Water. U.S. Geological survey Water-Supply Paper 2254, 3rd Edition.

Killian, T.H., N.L. Colb, P. Corbo, and I.W. Marine. 1987a. F-Area Seepage Basins Enviroñmental Information Document. E.I. du Pont de Nemours and Co., Savannah River Laboratory, DPST-85-704.

Killian, T.H., N.L, Colb, P. Corbo, and I.W. Marine. 1987b. H-Area Seepage Basins Environmental Information Document. E.I. du Pont de Nemours and Co., Savannah River Laboratory, DPST-85-706.

Koch, J.W. and K.L. Dixon. 1996a. Results of the Tritium Survey of Fourmile Branch and its Seeplines in the F-and H-Areas of SRS: September 1996. Westinghouse Savannah River Company, WSRC-TR-97-0109.

Koch, J.W. and K.L. Dixon. 1996b. Results of the Tritium Survey of Fourmile Branch and its Seeplines in the F-and H-Areas of SRS: March 1996. Westinghouse Savannah River Company, WSRC-TR-96-0215.

Koch, J.W. and K.L. Dixon. 1995. Results of the Tritium Survey of Fourmile Branch and its Seeplines in the F-and H-Areas of SRS: May 1995. Westinghouse Savannah River Company, WSRC-TR-96-0369.

Koch, J.W. and K.L. Dixon. 1994. Results of the Tritium Survey of Fourmile Branch and its Seeplines in the F-and H-Areas of SRS: December 1994. Westinghouse Savannah River Company, WSRC-TR-95-0300.

Korthals, E.T. 1991. Assessment of the Toxicity of Seepage from the F and H Seepage Basins Located on the Savannah River Site. Normandeau Associates, Inc., Aiken SC 29802.

Lauritsen, D., W. Starkel, and W.L. Specht. 1989. A Study of Post-Thermal Recovery of the Macroinvertebrate Community of Four Mile Creek June 1985 - September 1987. Westinghouse Savannah River Company, WSRC-TR-90-472.

LeBlanc, D.C. and C. Loehle. 1990. The Effect of Contaminated Groundwater on Tree Growth: A Tree-Ring Analysis. WSRC-RP-90-552.

Loehle, C. 1990a. Recovery of Contaminated Wetland Soils at SRS by Natural Rainfall: An Experimental, Toxicological Study. Westinghouse Savannah River Company, WSRC-RP-90-14.

Loehle, C. 1990b. Summary of Vegetation Stress Factors at F- and H-Area Seepage Basin Outcrop Zones. Westinghouse Savannah River Company, WSRC-RP-90-551.

Loehle, C. 1990c. Vegetation Survey of FourMile Creek Wetlands. Westinghouse Savannah River Company, WSRC-RP-90-1207.

Loehle, C., and M. Paller. 1990. Heavy Metals in Fish from Streams Near F-Area and H-Area Seepage Basins. Westinghouse Savannah River Company, WSRC-RP-90-482.

Looney, B.B., J.E. Cantrell, and J.R. Cook. 1988. Sampling and Analysis of Surface Water in the Vicinity of the F. and H-Area Seepage Basins. E.I. du Pont de Nemours and Company, Savannah River Laboratory, DPST-88-229.

Mackey, H.E. 1988. Initial Evaluation of Photographic Data of F- and H-Area Seepage Basin Outcrops. E.I. du Pont de Nemours and Company, Savannah River Laboratory, DPST-88-314. 
Metcalf and Eddy. 1994. Four Mile Creek Semi-Annual Sampling Report: April 1994 Sampling Event. Prepared for Westinghouse Savannah River Company, WSRC-TR-96-376.

Metcalf and Eddy. 1993a. Four Mile Creek Semi-Annual Sampling Report: January 1993 Sampling Event. Westinghouse Savannah River Company, WSRC-TR-93-320.

Metcalf and Eddy. 1993b. Four Mile Creek Semi-Annual Sampling Report: July 1993 Sampling Event. Westinghouse Savannah River Company, WSRC-TR-96-375.

Nelson, E.A. and V.A. Rogers. 1995. Survival of Planted Tupelo Seedlings in F- and H-Area Tree-Kill Zones. Westinghouse Savannah River Company, WSRC-TR-95-0025.

Nelson, E.A. and H.M. Westbury, Jr. 1994. Lettuce Seed Germination and Root Elongation Toxicity Evaluation of the F-Area Seepline Soils. Westinghouse Savannah River Company, WSRC-TR-94-0510.

Nelson, E.A., and J.E. Irwin. 1994. Current Vegetation Characteristics Within Tree-Kill Zones of F-and HAreas. Westinghouse Savannah River Company, WSRC-TR-94-0233.

Paller, M.H., M.J.M. Reichert, and J.M. Dean. 1995. Rapid bioassessment methods for streams on the Savannah River Site. Westinghouse Savannah River Company, WSRC-TR-95-0287.

Paller, M.H. and C. Storey. 1990. Effects of Outcropping Groundwater from the F- and H-Area Seepage Basins on the Distribution of Fish in Four Mile Creek. Westinghouse Savannah River Company, WSRC-TR$90-502$.

Parker, K., M.E. Hane, A.J. Lander, C.J. Richardson, and C. Loehle. December 1990. Assessment of tree toxicity near the F-and H-Area seepage basins of the Savannah River Site. Westinghouse Savannah River Company, WSRC-TR-90-253.

Railsback, L.B., P.A. Bouker, T.P. Feeney, E.A. Goddard, K.E. Goggin, A.S. Hall, B.P. Jackson, A.A. McLain, M.C. Orsega, M.A. Rafter, and J.W. Webster. 1996. "A Survey of the Major-element Geochemistry of Georgia Groundwater". Southeastern Geology Vol. 36:99-122.

Rogers \& Associates Engineering Corporation (RAEC). 1995. Five-Year Ecological Monitoring Plan for the F- and H-Area Seepage Basins Remediation Program. Draft Report RAE-9424/1-1, Salt Lake City, Utah.

Rogers, V.A. 1990.Soil Survey of Savannah River Plant Area, Parts of Aiken, Barnwell, and Allendale Counties, South Carolina. U.S. Department of Agriculture, Soil Conservation Service.

Rogers, V.A., K.L. Dixon, and B.B. Looney. 1994a. Results of the Quarterly Tritium Survey of Fourmile Branch and its Seeplines in the F and H Areas of SRS: December 1993. Westinghouse Savannah River Company, WSRC-TR-94-0342.

Rogers, V.A., K.L. Dixon, and B.B. Looney. 1994b. Results of the Quarterly Tritium Survey of Fourmile Branch and its Seeplines in the F and H Areas of SRS: March 1994. Westinghouse Savannah River Company, WSRC-TR-94-0408.

Specht, W.L. 1996. Toxicity of Water Samples Collected in the Vicinity of the F/H Seepage Basins, 19901995. Westinghouse Savannah River Company, WSRC-TR-96-0261.

Specht, W.L. and M.H. Paller. 1995. Rapid Bioassessment Methods for Assessing Stream Macroinvertebrate communities on the Savannah River Site. Westinghouse Savannah River Company,WSRC-TR-95-0351.

Specht, W.L. 1994a. Results of Macroinvertebrate Sampling Conducted at 33 SRS Stream Locations, JulyAugust 1993. Westinghouse Savannah River Company, WSRC-TR-95-0006. 
Specht, W.L. 1987. Comprehensive Cooling Water Study, Final Report, Vol. V: Aquatic Ecology. E.I. du Pont de Nemours and Company, DP-1739-5.

Strom, R.N. and D.S. Kaback. 1992. SRP Baseline Hydrogeologic Investigations: Aquifer CharacterizationGroundwater Geochemistry of the Savannah River Site and Vicinity. Westinghouse Savannah River Company, WSRC-RP-450.

U.S. Army Corps of Engineers. 1987. Corps of Engineers Wetlands Delineation Manual. Technical Report Y-87-1, Environmental laboratory, U.S. Army Engineer Waterways Experiment Station, Vicksburg, Mississippi.

U.S. Environmental Protection Agency (EPA). March 1997. Risk Based Concentration Table. Compiled by Roy L. Smith, Region III. http://www.epa.gov/reg3hwmd/risk/rbc971.htm.

U.S. Environmental Protection Agency (EPA). November 1995. Ecological Screening Values. Ecological Risk Assessment Bulletin No. 2, Supplemental Guidance to RAGS: Region 4 Bulletins, Atlanta, Ga.

Weber, C.I., W.H. Pelteir, T.J. Norberg-King, W.B. Horning, F.A. Kessler, J.R. Menkedick, T.W. Neilheisel, P.A. Lewis, D.J. Klemm, Q.H. Pickering, E.L. Robinson, J.M. Lazorchak, L.J. Wymer, and R.W. Freyberg. 1989. Short-term Methods for Estimating the Chronic Toxicity of Effluents and Receiving Waters to Freshwater Organisms. U.S. Environmental Protection Agency, EPA/600/4-89/001.

Westbury, H.M. Jr., and E.A. Nelson. 1994. Plant Community Development within the F- and H-Area TreeKill Zones. Westinghouse Savannah River Company, WSRC-TR-94-0544.

Wike, L.D., R.W. Shipley, J.A. Bowers, A.L. Bryan, C.L. Cummins, B. R. del Carmen, G.P. Friday, J.E. Irwin, H.E. Mackey, Jr., J.J. Meyer, E.A. Nelson, M.H. Paller, V.A. Rogers, W.L. Specht, and E.W. Wilde. April 1994. SRS Ecology-Environmental Information Document. Westinghouse Savannah River Company, WSRC-TR-93-496.

WSRC. 1996. Savannah River Site Environmental Report for 1995. Westinghouse Savannah River Company, WSRC-TR-96-0075.

WSRC. 1995a. Savannah River Site Environmental Report for 1994. Westinghouse Savannah River Company, WSRC-TR-95-075.

WSRC. 1995b. Quality Control Summary Report for the F/H Seepage Basins Ecological Management Plan Project. Westinghouse Savannah River Company, ESH-EMS-950564.

WSRC. 1995c. Quality Control Summary Report for the Burial Ground Ecological Risk Assessment- September 26, 1995. Westinghouse Savannah River Company, Environmental Protection Department/Environmental Monitoring Section, ESH-EMS-950562.

WSRC. 1995d. Screening Risk Assessment to Support an Alternate Concentration Limit/Mixing Zone Demonstration for the F- \& H-Area Seepage Basins Groundwater Unit. Westinghouse Savannah River Company, Draft Report.

WSRC. 1991. Savannah River Site Report. Westinghouse Savannah River Company, WSRC-IM-91-28. 


\section{APPENDIX A}

Coordinates for Sampling and Well Locations 
TABLE A1. Sediment sampling locations and SRS site coordinates, 1995 (WSRC 1996b).

\begin{tabular}{ccc}
\hline \hline Location & North & East \\
\hline BG001 & 67208 & 59153 \\
BG002 & 67229 & 59363 \\
BG003 & 67633 & 59281 \\
BG004 & 64723 & 68527 \\
FMC001F & 72200 & 43900 \\
FMC001H & 70350 & 57050 \\
FMC002H & 72600 & 53000 \\
T4/1108 & 70957 & 55717 \\
FSP012 & 73602 & 49644 \\
FSP019 & 73177 & 49778 \\
FSP026 & 72932 & 49801 \\
FSP032 & 73367 & 50258 \\
FSP035 & 73065 & 50297 \\
FSP047 & 73609 & 50607 \\
FSP204 & 73281 & 48801 \\
FSP290 & 73160 & 46865 \\
HSP008 & 71005 & 56990 \\
HSP025 & 70960 & 56297 \\
HSP029 & 71278 & 56257 \\
HSP043 & 71644 & 55722 \\
HSP052 & 71413 & 55743 \\
HSP060 & 71629 & 55190 \\
HSP092 & 72672 & 54129 \\
\hline & &
\end{tabular}


TABLE A2. Surface water sampling locations and SRS site coordinates, 1989-1996 (WSRC 1996b).

\begin{tabular}{ccc}
\hline Location & North & East \\
BG001 & 67208 & 59153 \\
BG002 & 67229 & 59363 \\
BG003 & 67633 & 59281 \\
BG004 & 64723 & 68527 \\
FMC001F & 72200 & 43900 \\
FMC001H & 70350 & 57050 \\
FMC002H & 72600 & 53000 \\
T4/1108 & 70957 & 55717 \\
FSP012 & 73602 & 49644 \\
FSP019 & 73177 & 49778 \\
FSP026 & 72932 & 49801 \\
FSP032 & 73367 & 50258 \\
FSP035 & 73065 & 50297 \\
FSP047 & 73609 & 50607 \\
FSP204 & 73609 & 50607 \\
FSP290 & 73609 & 50607 \\
HSP008 & 71005 & 56990 \\
HSP025 & 70960 & 56297 \\
HSP029 & 71278 & 56257 \\
HSP043 & 71644 & 55722 \\
HSP052 & 71413 & 55743 \\
HSP060 & 71629 & 55190 \\
HSP092 & 72672 & 54129 \\
\hline
\end{tabular}


TABLE A3. SRS site coordinates for piezometers in the F-and $\mathrm{H}$-Areas.

\begin{tabular}{ccc}
\hline \hline Piezometer No. & North & East \\
\hline FPZ001A & 73655 & 48785 \\
FPZ002A & 73720 & 48870 \\
FPZ003A & 73207 & 49097 \\
FPZ004A & 73696 & 49811 \\
FPZ005A & 73337 & 49723 \\
FPZ005B & 73337 & 49723 \\
FPZ006A & 73211 & 49825 \\
FPZ006B & 73211 & 49825 \\
FPZ007A & 73258 & 50245 \\
FPZ007B & 73258 & 50245 \\
FPZ008A & 73291 & 50616 \\
FPZ008B & 73291 & 50616 \\
HPZ001A & 71301 & 55676 \\
HPZ002A & 71692 & 56151 \\
HPZ003A & 70938 & 56294 \\
HPZ003B & 70938 & 56294 \\
HPZ004A & 71155 & 56573 \\
HPZ005A & 70995 & 56890 \\
HPZ005B & 70995 & 56890 \\
HPZ006A & 70583 & 56839 \\
\hline
\end{tabular}


TABLE A4. Site grid coordinates used to delineate jurisdictional wetlands, 1993.

\begin{tabular}{|c|c|c|}
\hline Location & North & East \\
\hline 1 & 72841.34222 & 49044.22060 \\
\hline 2 & 72790.69763 & 49065.92426 \\
\hline 3 & 72820.69830 & 49150.89457 \\
\hline 4 & 72852.49897 & 49249.13695 \\
\hline 5 & 72870.19993 & 49298.17702 \\
\hline 6 & 72932.50384 & 49383.18673 \\
\hline 7 & 73016.91358 & 49472.65275 \\
\hline 8 & 73028.19446 & 49531.85553 \\
\hline 9 & 73079.25712 & 49548.89080 \\
\hline 10 & 73166.54831 & 49601.72865 \\
\hline 11 & 73252.13345 & 49611.31879 \\
\hline 12 & 73309.09988 & 49575.08810 \\
\hline 13 & 73351.73047 & 49552.61749 \\
\hline 14 & 73394.29403 & 49575.02283 \\
\hline 15 & 73451.70347 & 49661.53481 \\
\hline 16 & 73504.53974 & 49684.97778 \\
\hline 17 & 73571.86421 & 49646.00969 \\
\hline 18 & 73639.62073 & 49622.41845 \\
\hline 19 & 73688.63460 & 49655.39420 \\
\hline 20 & 73725.05344 & 49718.10357 \\
\hline 21 & 73712.10522 & 49803.10572 \\
\hline 22 & 73656.63266 & 49854.39339 \\
\hline 23 & 73601.93007 & 49883.60591 \\
\hline 24 & 73535.85331 & 49915.15607 \\
\hline 25 & 73451.57422 & 49940.18731 \\
\hline 26 & 73395.97971 & 49916.31643 \\
\hline 27 & 73355.78744 & 49858.60356 \\
\hline 28 & 73321.79952 & 49837.43654 \\
\hline 29 & 73280.00224 & 49814.90518 \\
\hline 30 & 73219.93051 & 49816.72396 \\
\hline 31 & 73181.53612 & 49820.00255 \\
\hline 32 & 73167.40205 & 49811.35788 \\
\hline 33 & 73136.16284 & 49810.58316 \\
\hline 34 & 73138.59094 & 49863.83782 \\
\hline 35 & 73127.07329 & 49918.88131 \\
\hline 36 & 73150.11728 & 49987.84023 \\
\hline 37 & 73172.93372 & 50033.42744 \\
\hline
\end{tabular}


TABLE A4. (Continued)Site grid coordinates used to delineate jurisdictional wetlands, 1993.

\begin{tabular}{|c|c|c|}
\hline Location & North & East \\
\hline 38 & 73217.46611 & 50130.11073 \\
\hline 39 & 73246.36890 & 50114.13346 \\
\hline 40 & 73304.08628 & 50108.60829 \\
\hline 41 & 73359.39361 & 50174.90731 \\
\hline 42 & 73344.22653 & 50308.53865 . \\
\hline 43 & 73364.73206 & 50319.93478 \\
\hline 44 & 73275.81400 & 50315.12179 \\
\hline 45 & 73206.60650 & 50306.91554 \\
\hline 46 & 73112.77350 & 50313.14559 \\
\hline 47 & 73095.16048 & 50341.73179 \\
\hline 48 & 73083.65932 & 50417.23624 \\
\hline 49 & 73081.20913 & 50435.06242 \\
\hline 50 & 73046.07687 & 50525.46763 \\
\hline 51 & 73027.19723 & 50603.02206 \\
\hline 52 & 73090.44605 & 50625.72707 \\
\hline 53 & 73137.91544 & 50580.44984 \\
\hline 54 & 73219.37577 & 50555.11210 \\
\hline 55 & 73283.92846 & 50555.52213 \\
\hline 56 & 73352.34278 & 50508.38124 \\
\hline 57 & 73415.98908 & 50482.63149 \\
\hline 58 & 73470.93976 & 50409.01193 \\
\hline 59 & 73557.52705 & 50384.38394 \\
\hline 60 & 73643.16095 & 50364.58409 \\
\hline 61 & 73723.09253 & 50454.48475 \\
\hline 62 & 73726.33538 & 50566.12743 \\
\hline 63 & 73649.31416 & 50612.11390 \\
\hline 64 & 73560.92764 & 50632.34350 \\
\hline 65 & 73513.03175 & 50671.39331 \\
\hline 66 & 73528.90061 & 50721.70225 \\
\hline 67 & 73584.43344 & 50775.57927 \\
\hline 68 & 73648.20015 & 50809.65769 \\
\hline 69 & 73657.81229 & 50882.04148 \\
\hline 70 & 73630.41786 & 50921.86327 \\
\hline 71 & 73627.58096 & 51001.52438 \\
\hline 72 & 73564.01802 & 51071.22060 \\
\hline 73 & 73493.16944 & 51067.31597 \\
\hline 74 & 73428.70362 & 51010.82847 \\
\hline 75 & 73355.25485 & 50974.81003 \\
\hline
\end{tabular}


TABLE A4. (Continued)Site grid coordinates used to delineate jurisdictional wetlands, 1993.

\begin{tabular}{|c|c|c|}
\hline Location & North & $\overline{\text { East }}$ \\
\hline 76 & 73331.08630 & 50875.07597 \\
\hline 77 & 73270.46843 & 50789.01971 \\
\hline 78 & 73213.59234 & 50773.11879 \\
\hline 79 & 73137.41783 & 50736.60572 \\
\hline 80 & 73066.91505 & $50746: 45588$ \\
\hline 81 & 73050.95495 & 50786.20601 \\
\hline 82 & 73097.03213 & 50864.66713 \\
\hline 83 & 73165.67242 & 50952.67123 \\
\hline 84 & 73215.49078 & 51031.61951 \\
\hline 85 & 73266.99617 & 51136.89914 \\
\hline 86 & 73239.46818 & 51217.06716 \\
\hline 87 & 73238.80840 & 51298.37155 \\
\hline 88 & 73234.70802 & 51380.34174 \\
\hline 89 & 73256.22226 & 51463.76595 \\
\hline 90 & 73312.10534 & 51400.79246 \\
\hline 91 & 73412.96805 & 51370.36954 \\
\hline 92 & 73477.17622 & 51381.03289 \\
\hline 93 & 73522.01765 & 51290.22335 \\
\hline 94 & 73524.36950 & 51184.45213 \\
\hline 95 & 73571.84016 & 51128.80490 \\
\hline 96 & 73633.77764 & 51178.48821 \\
\hline 97 & 73687.22071 & 51247.31329 \\
\hline 98 & 73750.00192 & 51330.70687 \\
\hline 99 & 73803.12080 & 51427.10975 \\
\hline 100 & 73881.38083 & 51455.38017 \\
\hline 101 & 73952.30833 & 51467.13609 \\
\hline 102 & 74003.40255 & 51461.80603 \\
\hline 103 & 74089.17878 & 51463.87640 \\
\hline 104 & 74152.43510 & 51521.95416 \\
\hline 105 & 74199.01106 & 51504.32784 \\
\hline 106 & 74217.52014 & 51574.50012 \\
\hline 107 & 74216.63899 & 51625.70262 \\
\hline 108 & 74150.93055 & 51669.40175 \\
\hline 109 & 74108.99332 & 51703.40688 \\
\hline 110 & 74022.72759 & 51692.12448 \\
\hline 111 & 73933.31056 & 51677.78650 \\
\hline 112 & 73877.60668 & 51631.51824 \\
\hline 113 & 73784.30223 & 51573.47442 \\
\hline
\end{tabular}


TABLE A4. (Continued)Site grid coordinates used to delineate jurisdictional wetlands, 1993.

\begin{tabular}{|c|c|c|}
\hline Location & North & $\overline{\overline{\text { East }}}$ \\
\hline 114 & 73693.52390 & 51535.23235 \\
\hline 115 & 73635.54775 & 51537.07156 \\
\hline 116 & 73362.59123 & 51593.37966 \\
\hline 117 & 73631.37830 & 51681.09454 \\
\hline 118 & 73662.47438 & 51732.14912 \\
\hline 119 & 73730.21744 & 51819.24907 \\
\hline 120 & 73783.83402 & 51848.26834 \\
\hline 121 & 73765.80670 & 51887.03387 \\
\hline 122 & 73717.99106 & 51926.60058 \\
\hline 123 & 73701.87016 & 51990.31940 \\
\hline 124 & 73727.69271 & 52090.87746 \\
\hline 125 & 73759.30327 & 52158.78222 \\
\hline 126 & 73730.03775 & 52256.12566 \\
\hline 127 & 73759.10824 & 52292.44105 \\
\hline 128 & 73751.37989 & 52364.77539 \\
\hline 129 & 73703.37593 & 52399.93696 \\
\hline 130 & 73595.80257 & 52368.39163 \\
\hline 131 & 73533.64241 & 52329.38406 \\
\hline 132 & 73411.19493 & 52415.23080 \\
\hline 133 & 73391.99875 & 52477.52435 \\
\hline 134 & 73284.67359 & 52569.54316 \\
\hline 135 & 73225.52625 & 52625.31188 \\
\hline 136 & 73228.30346 & 52689.53280 \\
\hline 137 & 73239.71838 & 52789.34492 \\
\hline 138 & 73141.51780 & 52860.66367 \\
\hline 139 & 73090.80702 & 52943.49984 \\
\hline 140 & 73085.73611 & 53035.30008 \\
\hline 141 & 72850.66338 & 52982.54979 \\
\hline 142 & 72652.16210 & 52938.60618 \\
\hline 143 & 72634.98802 & 53021.50885 \\
\hline 144 & 72799.19988 & 53056.86418 \\
\hline 145 & 72732.49714 & 53118.33302 \\
\hline 146 & 72734.84058 & 53202.59213 \\
\hline 147 & 72778.21238 & 53240.02000 \\
\hline 148 & 72837.43429 & 53161.58780 \\
\hline 149 & 72997.40869 & 53169.46324 \\
\hline 150 & 73140.11300 & 53223.85672 \\
\hline 151 & 73186.87806 & 53316.70549 \\
\hline
\end{tabular}


TABLE A4. (Continued)Site grid coordinates used to delineate jurisdictional wetlands, 1993.

\begin{tabular}{|c|c|c|}
\hline Location & North & East \\
\hline 152 & 73203.93476 & 53397.44405 \\
\hline 153 & 73221.03247 & 53450.06213 \\
\hline 154 & 73228.48826 & 53511.20766 \\
\hline 155 & 73337.97950 & 53565.79430 \\
\hline 156 & 73415.17444 & 53592.81030 \\
\hline 157 & 73531.88419 & 53646.00168 \\
\hline 158 & 73571.73289 & 53719.00323 \\
\hline 159 & 73514.84805 & 53848.53159 \\
\hline 160 & 73522.49697 & 53929.59603 \\
\hline 161 & 73675.60097 & 53994.35500 \\
\hline 162 & 73773.15154 & 53989.32868 \\
\hline 163 & 73866.42472 & 53992.73936 \\
\hline 164 & 73964.83520 & 54006.18031 \\
\hline 165 & 73956.12542 & 54071.17764 \\
\hline 166 & 73867.72711 & 54049.36245 \\
\hline 167 & 73834.48770 & 54078.55420 \\
\hline 168 & 73773.19870 & 54093.16210 \\
\hline 169 & 73695.04602 & 54135.93360 \\
\hline 170 & 73645.03032 & 54114.96578 \\
\hline 171 & 73631.50554 & 54173.51485 \\
\hline 172 & 73560.79997 & 54132.18490 \\
\hline 173 & 73464.86830 & 54063.13393 \\
\hline 174 & 73405.82836 & 53982.18571 \\
\hline 175 & 73378.25804 & 53901.72981 \\
\hline 176 & 73360.56130 & 53818.38937 \\
\hline 177 & 73258.26638 & 53748.60941 \\
\hline 178 & 73153.05014 & 53728.53688 \\
\hline 179 & 73036.68076 & 53780.09576 \\
\hline 180 & 72952.46258 & 53792.81834 \\
\hline 181 & 72902.59084 & 53831.70059 \\
\hline 182 & 72886.50845 & 53898.13281 \\
\hline 183 & 72876.77421 & 53976.92446 \\
\hline 184 & 72739.38738 & 54032.93192 \\
\hline 185 & 72767.20994 & 54107.60802 \\
\hline 186 & 72818.52637 & 54170.05482 \\
\hline 187 & 72870.73468 & 54239.63650 \\
\hline 188 & 72857.86926 & 54304.78935 \\
\hline 189 & 72834.43736 & 54337.86305 \\
\hline
\end{tabular}


TABLE A4. (Continued)Site grid coordinates used to delineate jurisdictional wetlands, 1993.

\begin{tabular}{|c|c|c|}
\hline Location & North & East \\
\hline 190 & 72792.93140 & 54376.70694 \\
\hline 191 & 72732.05625 & 54384.42884 \\
\hline 192 & 72684.41842 & 54386.03745 \\
\hline 193 & 72623.38223 & 54362.08122 \\
\hline 194 & 72569.98511 & 54373.89857 \\
\hline 195 & 72553.84806 & 54304.88921 \\
\hline 196 & 72518.06480 & 54244.97454 \\
\hline 197 & 72437.89892 & 54216.13832 \\
\hline 198 & 72376.25415 & 54150.93179 \\
\hline 199 & 72283.72313 & 54066.43602 \\
\hline 200 & 72234.96885 & 54101.49317 \\
\hline 201 & 72168.13542 & 54056.57484 \\
\hline 202 & 72113.43993 & 53908.74411 \\
\hline 203 & 72016.43166 & 53949.87132 \\
\hline 204 & 71899.33753 & 53999.52665 \\
\hline 205 & 71800.31498 & 54070.18527 \\
\hline 206 & 71744.67131 & 54197.07543 \\
\hline 207 & 71672.65920 & 54322.20187 \\
\hline 208 & 71614.74051 & 54443.24514 \\
\hline 209 & 71541.56122 & 54527.54984 \\
\hline 210 & 71508.81053 & 54654.47033 \\
\hline 211 & 71450.61593 & 54781.82934 \\
\hline 212 & 71478.85610 & 54826.38790 \\
\hline 213 & 71573.37358 & 54842.98001 \\
\hline 214 & 71588.44384 & 54894.49446 \\
\hline 215 & 71697.03754 & 54885.68916 \\
\hline 216 & 71722.85373 & 54833.95435 \\
\hline 217 & 71766.07823 & 54747.81617 \\
\hline 218 & 71781.40078 & 54649.01541 \\
\hline 219 & 71868.25095 & 54685.22158 \\
\hline 220 & 71951.32820 & 54724.57170 \\
\hline 221 & 71992.76456 & 54778.42805 \\
\hline 222 & 72039.09399 & 54837.47900 \\
\hline 223 & 71978.27310 & 54854.94788 \\
\hline 224 & 71909.74716 & 54911.00124 \\
\hline 225 & 71833.22346 & 54957.02258 \\
\hline 226 & 71745.90011 & 55013.82211 \\
\hline 227 & 71734.61729 & 55070.33297 \\
\hline
\end{tabular}


TABLE A4. (Continued)Site grid coórdinates used to delineate jurisdictional wetlands, 1993.

\begin{tabular}{|c|c|c|}
\hline Location & North & East \\
\hline 228 & 71700.35822 & 55106.29548 \\
\hline 229 & 71657.92340 & 55201.66518 \\
\hline 230 & 71640.95019 & 55267.45750 \\
\hline 231 & 71643.36863 & 55313.72690 \\
\hline 232 & 71630.34153 & 55365.98390 \\
\hline 233 & 71675.03405 & 55400.38443 \\
\hline 234 & 71675.02610 & 55414.62935 \\
\hline 235 & 71642.11019 & 55401.29793 \\
\hline 236 & 71592.90170 & 55483.11936 \\
\hline 237 & 71579.84751 & 55570.80414 \\
\hline 238 & 71602.43866 & 55605.25092 \\
\hline 239 & 71620.58805 & 55653.02012 \\
\hline 240 & 71632.79391 & 55695.49697 \\
\hline 241 & 71675.07580 & 55733.96146 \\
\hline 242 & 71747.14853 & 55741.77021 \\
\hline 243 & 71808.17823 & 55740.71565 \\
\hline 244 & 71867.04409 & 55748.46780 \\
\hline 245 & 71864.67321 & 55791.50106 \\
\hline 246 & 71857.24038 & 55837.82609 \\
\hline 247 & 71854.40746 & 55881.26404 \\
\hline 248 & 71848.49402 & 55910.61257 \\
\hline 249 & 71822.33500 & 55955.51709 \\
\hline 250 & 71785.18714 & 55985.85666 \\
\hline 251 & 71782.38144 & 56019.07160 \\
\hline 252 & 71794.75325 & 56074.64276 \\
\hline 253 & 71799.02427 & 56103.09970 \\
\hline 254 & 71776.71750 & 56181.43786 \\
\hline 255 & 71686.10152 & 56202.88132 \\
\hline 256 & 71651.22997 & 56266.37167 \\
\hline 257 & 71602.68613 & 56272.31277 \\
\hline 258 & 71537.85048 & 56308.78833 \\
\hline 259 & 71494.60756 & 56343.46960 \\
\hline 260 & 71432.33943 & 56329.96654 \\
\hline 261 & 71374.84025 & 56292.91175 \\
\hline 262 & 71304.09351 & 56277.27839 \\
\hline 263 & 71252.56267 & 56235.09915 \\
\hline 264 & 71178.38139 & 56199.43077 \\
\hline 265 & 71096.10367 & 56235.70671 \\
\hline
\end{tabular}


TABLE A4. (Continued)Site grid coordinates used to delineate jurisdictional wetlands, 1993.

\begin{tabular}{|c|c|c|}
\hline Location & North & East \\
\hline 266 & 71028.68249 & 56246.19085 \\
\hline 267 & 70980.41146 & 56251.98551 \\
\hline 268 & 70969.06325 & 56374.37386 \\
\hline 269 & 70933.01817 & 56447.87644 \\
\hline 270 & 70951.85485 & 56492.29573 \\
\hline 271 & 71018.81769 & 56512.33204 \\
\hline 272 & 71078.37911 & 56495.55954 \\
\hline 273 & 71139.68442 & 56492.32079 \\
\hline 274 & 71195.14045 & 56502.58021 \\
\hline 275 & 71236.61342 & 56502.31339 \\
\hline 276 & 71249.44245 & 56526.98892 \\
\hline 277 & 71265.12554 & 56587.53216 \\
\hline 278 & 71272.64862 & 56666.42828 \\
\hline 279 & 71227.42906 & 56744.24865 \\
\hline 280 & 71187.61916 & 56767.08919 \\
\hline 281 & 71151.23985 & 56791.43820 \\
\hline 282 & 71099.76921 & 56796.09380 \\
\hline 283 & 71092.00919 & 56846.63532 \\
\hline 284 & 71110.86538 & 56920.13907 \\
\hline 285 & 71131.40305 & 56968.57636 \\
\hline 286 & 71104.69208 & 57043.85595 \\
\hline 287 & 71077.82008 & 57099.40872 \\
\hline 288 & 71061.18221 & 57158.65502 \\
\hline 289 & 70969.19611 & 57189.67073 \\
\hline 290 & 70910.77081 & 57151.23690 \\
\hline 291 & 70882.53895 & 57097.39075 \\
\hline 292 & 70872.99419 & 57068.36013 \\
\hline 293 & 70879.77612 & 56974.16440 \\
\hline 294 & 70838.64579 & 56913.70256 \\
\hline 295 & 70743.20412 & 56923.55735 \\
\hline 296 & 70688.43393 & 56968.68178 \\
\hline 297 & 70621.66833 & 57079.54558 \\
\hline 298 & 70613.95053 & 57139.59273 \\
\hline 299 & 70574.95565 & 57223.98937 \\
\hline 300 & 70476.03327 & 57149.87421 \\
\hline 301 & 70491.06574 & 57134.28080 \\
\hline 302 & 70456.08952 & 57167.83047 \\
\hline 303 & 70440.41990 & 57180.67703 \\
\hline
\end{tabular}


TABLE A4. (Continued)Site grid coordinates used to delineate jurisdictional wetlands, 1993.

\begin{tabular}{|c|c|c|}
\hline Location & North & East \\
\hline 304 & 70409.10336 & 57115.98404 \\
\hline 305 & 70429.43191 & 57097.75177 \\
\hline 306 & 70436.26302 & 57196.03493 \\
\hline 307 & 70442.72945 & 57256.39302 \\
\hline 308 & 70508.32918 & 57357.43842 \\
\hline 309 & 70474.29322 & 57445.94152 \\
\hline 310 & 70449.25149 & 57518.47331 \\
\hline 311 & 70469.74336 & 57589.86568 \\
\hline 312 & 70538.40910 & 57658.79820 \\
\hline 313 & 70603.98373 & 57744.13125 \\
\hline 314 & 70642.04818 & 57784.66913 \\
\hline 315 & 70710.39669 & 57838.05654 \\
\hline 316 & 70810.86010 & 57888.05416 \\
\hline 317 & 70805.55332 & 57909.32912 \\
\hline 318 & 72636.38015 & 53001.85762 \\
\hline 319 & 72562.86559 & 52989.36205 \\
\hline 320 & 72569.88034 & 52941.13636 \\
\hline 321 & 72645.72723 & 52953.73193 \\
\hline 1000 & 72855.45000 & 49062.78000 \\
\hline 1002 & 72937.27415 & 49351.39023 \\
\hline 1003 & 73155.99617 & 49520.15344 \\
\hline 1004 & 73412.06315 & 49572.31033 \\
\hline 1005 & 73762.56859 & 49606.35003 \\
\hline 1006 & 73615.77064 & 49888.56337 \\
\hline 1007 & 73323.02204 & 49936.70830 \\
\hline 1008 & 73389.26692 & 50339.17372 \\
\hline 1009 & 73791.73248 & 50382.43158 \\
\hline 1010 & 73606.28735 & 50815.53074 \\
\hline 1011 & 73583.36392 & 50834.00451 \\
\hline 1012 & 73640.76227 & 51123.16435 \\
\hline 1013 & 73323.26277 & 51011.35858 \\
\hline 1014 & 73481.12457 & 51292.55000 \\
\hline 1015 & 73980.56573 & 51379.05419 \\
\hline 1016 & 73776.07471 & 51682.81191 \\
\hline 1017 & 73820.47374 & 52204.38836 \\
\hline 1018 & 73360.29476 & 52622.51990 \\
\hline 1019 & 73059.82901 & 53039.30479 \\
\hline 1021 & 73828.59000 & 53144.50000 \\
\hline
\end{tabular}


TABLE A4. (Continued)Site grid coordinates used to delineate jurisdictional wetlands, 1993.

\begin{tabular}{ccc}
\hline \hline Location & North & East \\
\hline $\mathbf{1 0 2 2}$ & 72995.29762 & 53088.79975 \\
$\mathbf{1 0 2 3}$ & 73210.10154 & 53521.00373 \\
$\mathbf{1 0 2 4}$ & 73503.24735 & 53724.54520 \\
$\mathbf{1 0 2 5}$ & 73629.23924 & 53877.09755 \\
$\mathbf{1 0 2 6}$ & 73333.50696 & 53851.46702 \\
$\mathbf{1 0 2 7}$ & 72978.94881 & 53628.01696 \\
$\mathbf{1 0 2 8}$ & 72824.09884 & 54165.81835 \\
$\mathbf{1 0 2 9}$ & 72560.01356 & 54334.79634 \\
$\mathbf{1 0 3 0}$ & 72071.06815 & 54178.50318 \\
$\mathbf{1 0 3 1}$ & 71869.74478 & 54381.88280 \\
$\mathbf{1 0 3 2}$ & 71766.42100 & 54648.23676 \\
$\mathbf{1 0 3 3}$ & 71883.92047 & 55000.64301 \\
$\mathbf{1 0 3 4}$ & 71674.96874 & 55466.74763 \\
$\mathbf{1 0 3 5}$ & 71872.83618 & 55701.88699 \\
$\mathbf{1 0 3 6}$ & 71978.40385 & 55966.00325 \\
$\mathbf{1 0 3 7}$ & 71595.51511 & 56492.67141 \\
$\mathbf{1 0 3 8}$ & 71354.52764 & 56372.47719 \\
$\mathbf{1 0 3 9}$ & 71385.31974 & 56433.82999 \\
$\mathbf{1 0 4 0}$ & 71064.68821 & 56430.41315 \\
$\mathbf{1 0 4 1}$ & 71265.91859 & 56945.22308 \\
$\mathbf{1 0 4 2}$ & 71226.77383 & 56867.11146 \\
$\mathbf{1 0 4 3}$ & 71091.95134 & 57229.97257 \\
$\mathbf{1 0 4 4}$ & 71033.27803 & 57325.21351 \\
$\mathbf{1 0 4 5}$ & 70805.45212 & 57218.03241 \\
$\mathbf{1 0 4 6}$ & 70485.85706 & 57209.97051 \\
$\mathbf{1 0 4 7}$ & 70507.41010 & 57571.59442 \\
$\mathbf{1 0 4 8}$ & 70759.32899 & 57702.14899 \\
\hline & & \\
\hline & & \\
\hline
\end{tabular}


TABLE A5. Toxicity sampling locations and site grid coordinates, 1990-1994.

\begin{tabular}{lcc}
\hline \hline Location & North & East \\
\hline FSP-012 & 73602 & 49644 \\
FSP-032 & 73367 & 50258 \\
FSP-047 & 73609 & 50607 \\
FSP-204 & 73609 & 50607 \\
FSP-256 & 73435 & 47770 \\
HSP-008 & 71005 & 56990 \\
HSP-020 & 71142 & 56489 \\
HSP-043 & 71644 & 57722 \\
HSP-060 & 71629 & 55190 \\
HSP-103 & 72448 & 53665 \\
H-6 & 71041 & 56394 \\
FMC-001F & 70350 & 57050 \\
FMC-001H & 72600 & 53000 \\
FMC-002H & 72200 & 43900 \\
FMC Road C-4 & 72610 & 48812 \\
FMC Road A-7 & 69279 & 40079 \\
UTR-022 & 74990 & 61270 \\
UTR-029 & 74855 & 60792 \\
UTR-116 & 79665 & 59050 \\
BGW-045 & 94651 & 82775 \\
UTR RR Bridge & 83358 & 51854 \\
\hline
\end{tabular}


TABLE A6. Coordinates for Extraction and Injection Wells at F-Area.

\begin{tabular}{lcc}
\hline \hline Well ID & SRS North & SRS East \\
\hline FEX-1 & 73880.37 & 50173.48 \\
FEX-2 & 73704.62 & 50026.34 \\
FEX-3 & 73892.03 & 49873.51 \\
FEX-4 & 73973.40 & 49637.70 \\
FEX-5 & 73955.14 & 49421.42 \\
FEX-6 & 74060.50 & 49200.07 \\
FEX-7 & 74215.53 & 48967.71 \\
FEX-8 & 74771.03 & 49643.83 \\
FEX-9 & 74575.58 & 49954.33 \\
FEX-10 & 74702.87 & 50082.12 \\
FEX-11 & 74802.41 & 49913.99 \\
FIN-1 & 75814.61 & 50079.83 \\
FIN-2 & 75820.25 & 50365.50 \\
FIN-3 & 75720.85 & 50599.29 \\
FIN-4 & 75639.56 & 50759.67 \\
FIN-5 & 75708.32 & 51004.50 \\
FIN-6 & 75746.73 & 51766.90 \\
FIN-7 & 75599.62 & 51870.21 \\
FIN-8 & 75770.28 & 50680.18 \\
FIN-9 & 75723.19 & 51841.41 \\
FIN-10 & 75580.00 & 49809.66 \\
\hline
\end{tabular}


TABLE A7. Coordinates for Extraction and Injection Wells at H-Area.

\begin{tabular}{lcc}
\hline Well ID & SRS North & SRS East \\
\hline HEX-1 & 71957.13 & 56408.18 \\
HEX-2 & 71892.34 & 56526.80 \\
HEX-3 & 71225.27 & 56921.87 \\
HEX-4 & 71203.62 & 56979.12 \\
HEX-5 & 70691.95 & 57158.22 \\
HEX-6 & 70637.70 & 57191.36 \\
HEX-7 & 70549.05 & 57333.00 \\
HEX-8 & 70556.36 & 57497.55 \\
HEX-9 & 71371.66 & 58291.01 \\
HEX-10 & 71492.96 & 58365.81 \\
HEX-11 & 71670.44 & 58588.88 \\
HEX-12 & 72155.84 & 55787.22 \\
HEX-13 & 72061.35 & 55857.14 \\
HEX-14 & 72039.16 & 55890.93 \\
HEX-15 & 72012.53 & 55932.41 \\
HEX-16 & 72377.35 & 56061.07 \\
HEX-17 & 71887.19 & 56147.06 \\
HEX-18 & 71337.24 & 57796.36 \\
HEX-19 & 70934.79 & 57759.43 \\
HIN-1 & 73072.22 & 56839.33 \\
HIN-2 & 72291.93 & 58142.14 \\
HIN-3 & 72403.99 & 58310.96 \\
HIN-4 & 72290.87 & 58507.61 \\
HIN-5 & 72291.60 & 58611.08 \\
HIN-6 & 73361.46 & 56665.84 \\
HIN-7 & 73292.10 & 56745.25 \\
HIN-8 & 72950.83 & 57000.53 \\
HIN-9 & 72863.13 & 57174.30 \\
HIN-10 & 72384.94 & 57899.92 \\
\hline & & \\
\hline
\end{tabular}




\section{APPENDIX B}

Sediment and Surface Water Statistics for 1995 and 1996 
TABLE B1. Mean concentration and 95\% upper confidence intervals (UCD) of non-radiological constituents in sediment, 1995 (WSRC 1995b).

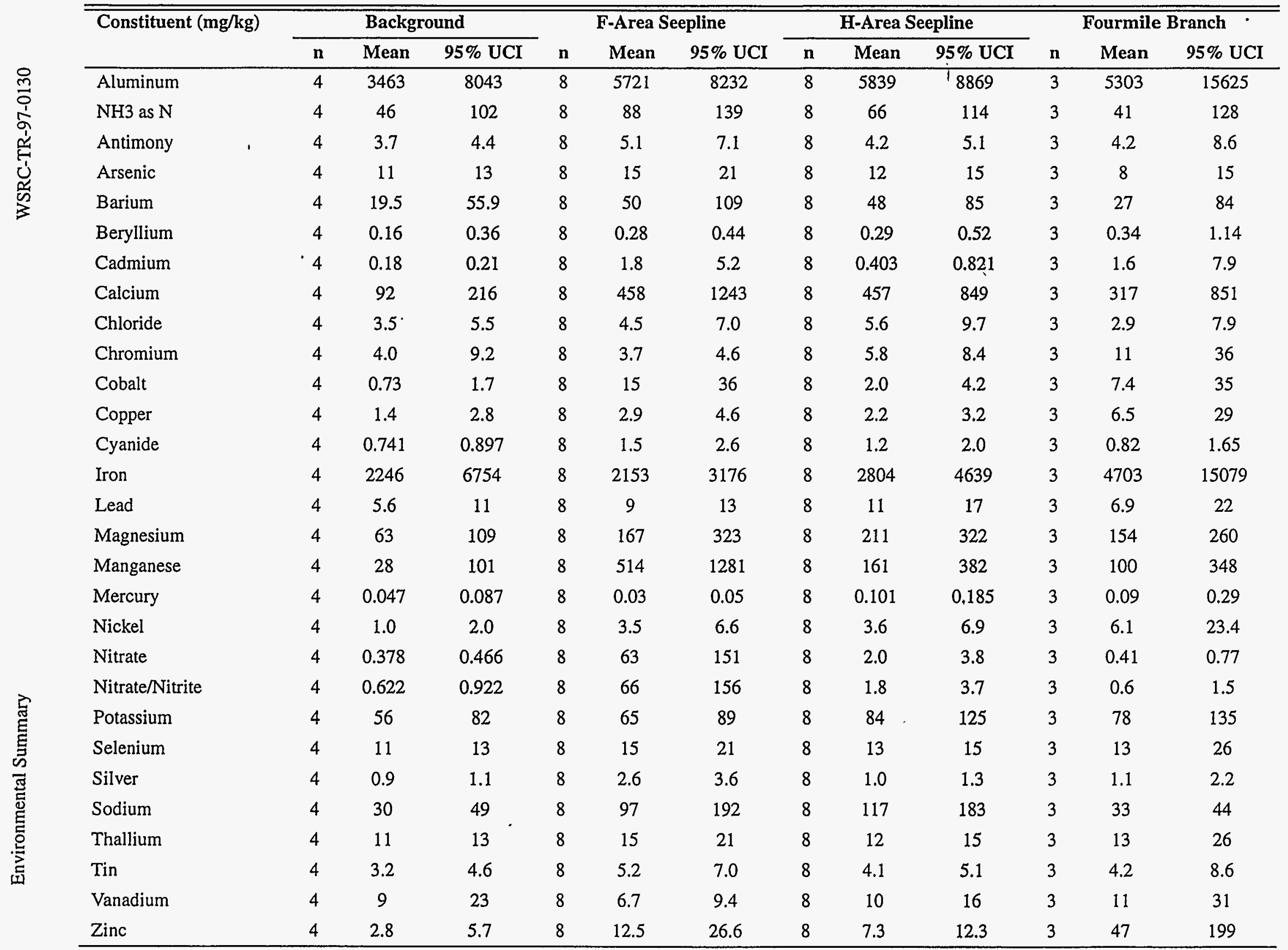


TABLE B2. Mean radioactivity (pCi/g) and 95\% upper confidence intervals (UCD) of radioisotopes in sediment, 1995 (WSRC 1995b).

\begin{tabular}{|c|c|c|c|c|c|c|c|c|c|c|c|c|}
\hline \multirow[t]{2}{*}{ Constituent } & \multicolumn{3}{|c|}{ Background } & \multicolumn{3}{|c|}{ F-Area Seepline } & \multicolumn{3}{|c|}{ H-Area Seepline } & \multicolumn{3}{|c|}{ Fourmile Branch } \\
\hline & $\mathbf{n}$ & Mean & $95 \%$ UCI & $\mathbf{n}$ & Mean & 95\% UCI & $n$ & Mean & $95 \%$ UCI & $\mathbf{n}$ & Mean & $95 \%$ UCI \\
\hline Ac-228 & 4 & 0.7 & 1.6 & 8 & 0.9 & 1.4 & 8 & 0.7 & 1.1 & 3 & 1.6 & 3.0 \\
\hline Gross Alpha & 4 & 9.3 & $15: 4$ & 8 & 25.2 & 50.7 & 8 & 20.7 & 33.6 & 3 & 38 & 128 \\
\hline Am-241 & 4 & 0.008 & 0.018 & 8 & 0.19 & 0.48 & 8 & 0.009 & 0.014 & 3 & 0.2 & 1.2 \\
\hline $\mathrm{Ba}-133$ & 4 & 0.0002 & 0.0087 & 8 & -0.0027 & 0.0086 & 8 & -0.008 & 0.009 & 3 & $0: 013$ & 0.059 \\
\hline Gross Beta & 4 & 6.7 & 10.7 & 8 & 40.8 & 89.0 & 8 & 72.8 & 168.6 & 3 & 70 & 257 \\
\hline $\mathrm{Ce}-144$ & 4 & 0.006 & 0.0422 & 8 & 0.0064 & 0.059 & 8 & 0.035 & 0.117 & 3 & -0.027 & 0.154 \\
\hline Co-57 & 4. & 0.0009 & 0.0042 & 8 & 0.0022 & 0.0043 & 8 & 0.0004 & 0.0044 & 3 & -0.0019 & 0.0031 \\
\hline $\mathrm{Co}-58$ & 4 & -0.0028 & 0.0023 & 8 & 0.0017 & 0.0042 & 8 & -0.016 & 0.027 & 3 & -0.0022 & 0.016 \\
\hline Co-60 & 4 & 0.001 & 0.0024 & 8 & 0.1439 & 0.3058 & 8 & 11.2 & 36.9 & 3 & 0.234 & 1.134 \\
\hline Cs-134 & 4 & 0.0015 & 0.0068 & 8 & -0.0015 & 0.0036 & 8 & -0.022 & 0.013 & 3 & -0.006 & 0.0578 \\
\hline Cs-137 & 4 & 0.17 & 0.332 & 8 & 0.495 & 0.811 & 8 & 0.679 & 1.17 & 3 & 54 & 205 \\
\hline Eu-152 & 4 & -0.0048 & 0.0062 & 8 & -0.0096 & -0.001 & 8 & -0.0009 & 0.033 & 3 & -0.03 & -0.008 \\
\hline Eu-154 & 4 & -0.004 & 0.025 & 8 & 0.039 & 0.099 & 8 & -0.095 & 0.317 & 3 & 0.039 & 0.22 \\
\hline Eu-155 & 4 & 0.01 & 0.029 & 8 & 0.024 & 0.049 & 8 & 0.018 & 0.052 & 3 & 0.016 & 0.087 \\
\hline I-129 & 4 & 0.08 & 0.178 & 8 & 8.6 & 23.5 & 8 & 1.25 & 2.56 & 3 & -0.01 & 0.423 \\
\hline $\mathrm{K}-40$ & 4 & 1.2 & 3.2 & 8 & 0.805 & 1.02 & 8 & 1.21 & 2.15 & 3 & 1.16 & 1.97 \\
\hline$M n-54$ & 4 & 0.01 & $: 0.031$ & 8 & 0.016 & 0.025 & 8 & 0.015 & 0.026 & 3 & 0.024 & 0.043 \\
\hline $\mathrm{Na}-22$ & 4 & -0.0005 & 0.0021 & 8 & 0.0015 & 0.0046 & 8 & $-0,0015$ & 0.0011 & 3 & 0.001 & 0.002 \\
\hline $\mathrm{Ni}-63$ & 4 & 0.65 & 1.58 & 8 & 0.425 & 0.925 & 8 & 22.34 & 71.29 & 3 & 0.754 & 2.812 \\
\hline Np-237 & 4 & 0.031 & 0.076 & 8 & $0.035^{\circ}$ & 0.073 & 8 & 0.803 & 2.33 & 3 & 0.08 & 0.378 \\
\hline Np-239 & 4 & 0.014 & 0.068 & 8 & 0.012 & 0.023 & 8 & 0.029 & 0.104 & 3 & 0.067 & . $\quad 0.406$ \\
\hline $\mathrm{Pb}-212$ & 4 & 0.7 & 1.60 & 8 & 0.99 & 1.54 & 8 & 1.22 & 2.17 & 3 & 1.69 & 3.59 \\
\hline
\end{tabular}


TABLE B2. (Continued)Mean radioactivity (pCi/g) and 95\% upper confidence intervals (UCI) of radioisotopes in sediment, 1995 (WSRC 1995b).

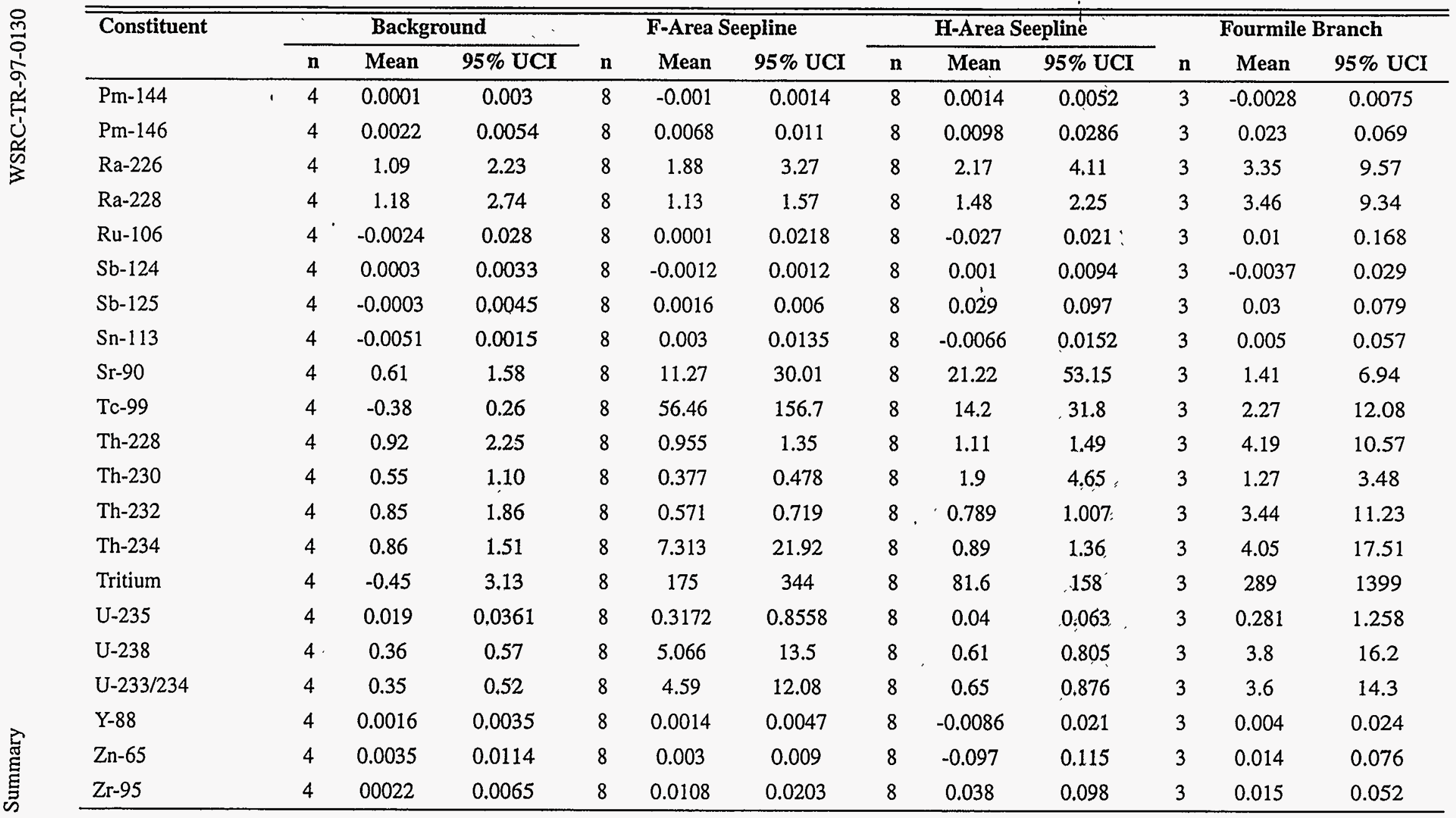


TABLE B3. Mean concentrations $(\mu \mathrm{g} / \mathrm{L})$ and $95 \%$ upper confidence intervals of non-radiological constituents in surface water, 1995 (WSRC 1995b). [Note: Values denoted by an asterisk represent one-half the detection limit.]

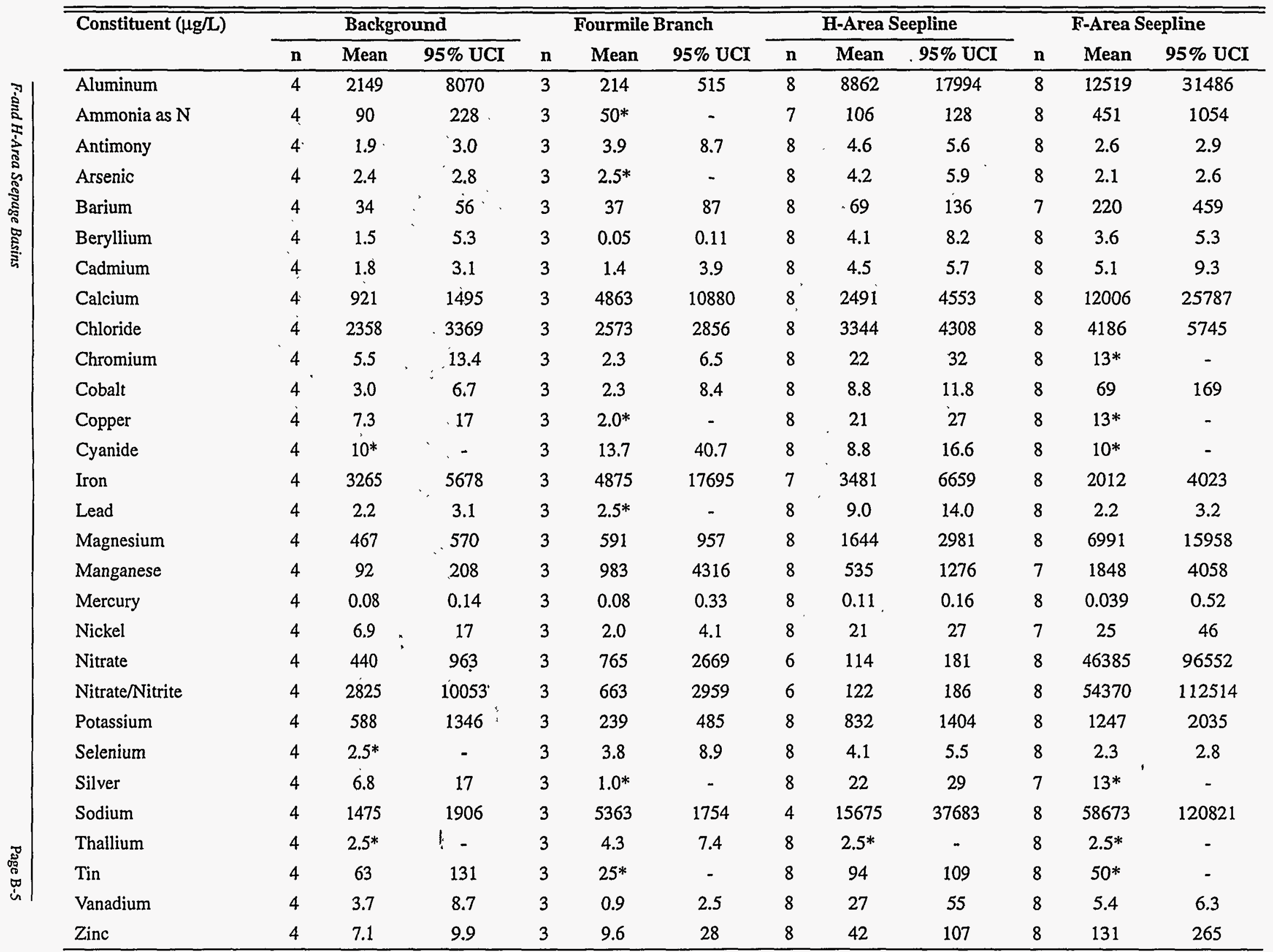




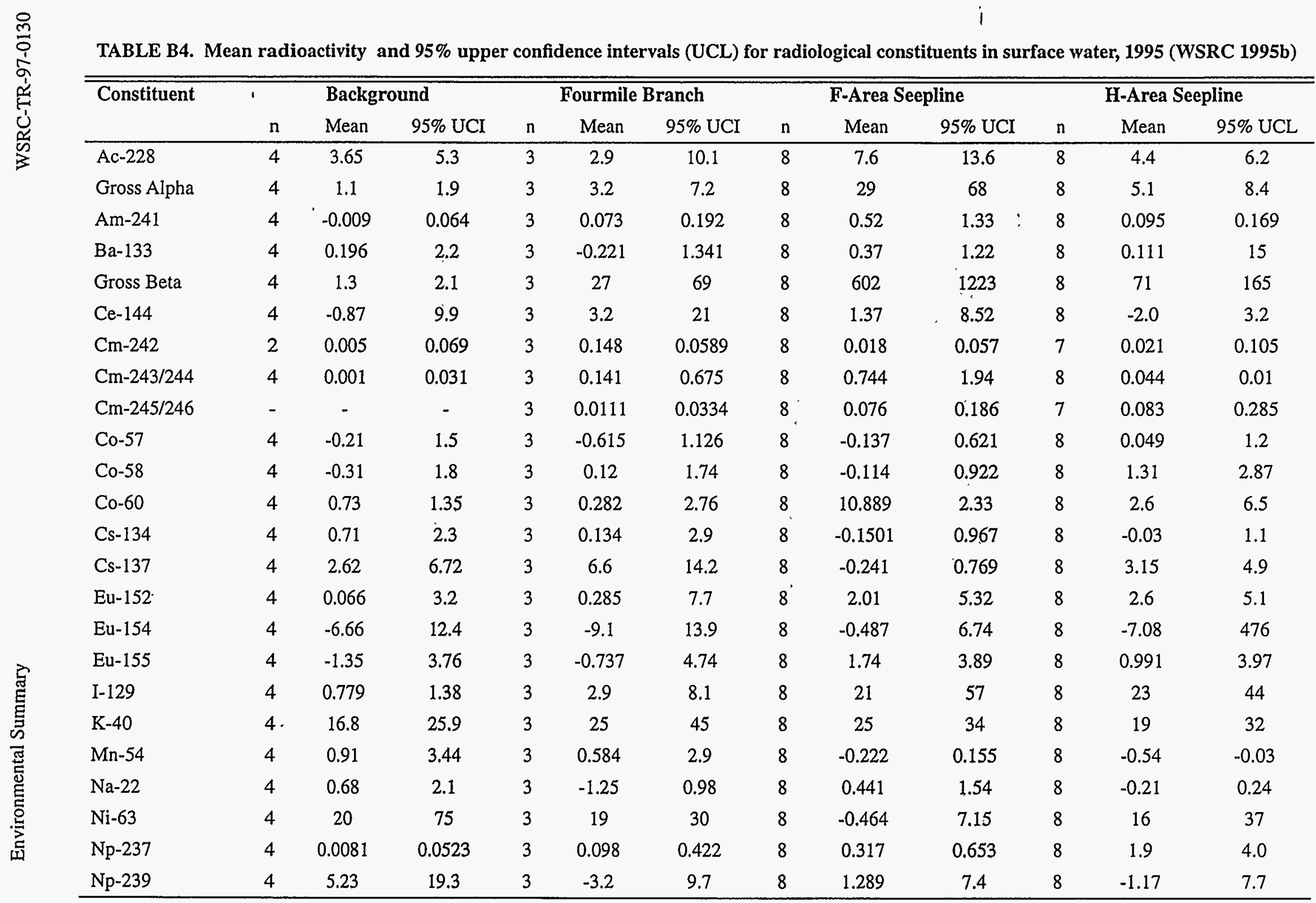


TABLE B4. (Continued)Mean radioactivity and 95\% upper confidence intervals (UCL) for radiological constituents in surface water, 1995 (WSRC

\begin{tabular}{|c|c|c|c|c|c|c|c|c|c|c|c|c|}
\hline \multirow[t]{2}{*}{ Constituent } & \multicolumn{3}{|c|}{ Background } & \multicolumn{3}{|c|}{ Fourmile Branch } & \multicolumn{3}{|c|}{ F-Area Seepline } & \multicolumn{3}{|c|}{ H-Area Seepline } \\
\hline & $\mathrm{n}$ & Mean & $95 \%$ UCI & $\mathrm{n}$ & Mean & $95 \% \mathrm{UCI}$ & $\mathrm{n}$ & Mean & $95 \%$ UCI & $\mathrm{n}$ & Mean & 95\% UCL \\
\hline $\mathrm{Pb}-212$ & 4 & 1.54 & 4.86 & 3 & 2.3 & 7.9 & 8 & 4.2 & 5.8 & 8 & 1.4 & 2.6 \\
\hline Pm-144 & 4 & 0.289 & $1.51^{\prime}$ & 3 & 0.16 & 1.77 & 8 & -0.186 & 0.69 & 8 & -0.246 & 0.25 \\
\hline$P m-146$ & 4 & 0.472 & 3.1 & 3 & -0.566 & 0.531 & 8 & -0.162 & 1.38 & 8 & 0.322 & 1.724 \\
\hline $\mathrm{Ra}-226$ & 4 & 0.626 & 1.267 & 3 & 0.496 & 1.5 & 8 & 5.4 & 13.3 & 8 & 0.5 & 0.8 \\
\hline $\mathrm{Ra}-228$ & 4 & -1.05 & -0.16 & 3 & -0.45 & 0.03 & 8 & 4.8 & 13.3 & 8 & -0.066 & 0.60 \\
\hline Ru-106 & 4 & 2.42 & 11.7 & 3 & 3.27 & 33 & 8 & 1.7 & 9.9 & 8 & 3.61 & 4.0 \\
\hline Sb-124 & 4 & -2.06 & 0.747 & 3 & 0.126 & 3.07 & 8 & 0.0623 & 1.4 & 8 & -0.31 & 0.29 \\
\hline Sb-125 & 4 & 1.792 & 3.565 & 3 & 0.8 & 6.2 & 8 & 0.379 & 178 & 8 & -0.378 & 362 \\
\hline Sn-113 & 4 & 0.034 & 2.63 & 3 & -0.64 & 2.3 & 8 & 0.323 & 1.42 & 8 & 0.18 & 2.06 \\
\hline $\mathrm{Sr}-90$ & 4 & 1.89 & 5 & 3 & 13 & 36 & 8 & 490 & 1148 & 8 & 21 & 45 \\
\hline Tc-99 & 4 & -7.0 & 1.9 & 3. & -6.7 & 1.9 & 8 & 22 & 45 & 8 & 51 & 91 \\
\hline Th-228 & 4 & 0.346 & 1.02 & 3 & 0.004 & 0.271 & 8 & 0.224 & 0.381 & 8 & 0.49 & 0.76 \\
\hline Th-230 & 4 & 0.038 & 0.12 & 3 & 0.58 & 0.37 & 8 & 0.82 & 1.6 & 8 & 0.09 & 0.14 \\
\hline Th-232 & 4 & 0.036 & 0.135 & 3 & -0.011 & 0.003 & 8 & 0.076 & 0.151 & 8 & 0.013 & 0.034 \\
\hline Th-234 & 4 & 30.3 & 64.2 & 3 & 73 & 238 & 8 & 53 & 88 & 8 & 59 & 114 \\
\hline Tritium & 4 & 3695 & 7555 & 3 & 283833 & 1206165 & 8 & $2.99 E+06$ & $6.2 \mathrm{E}+06$ & 8 & $2.940 \mathrm{E}+06$ & $6.06 \mathrm{E}+06$ \\
\hline U-235 & 4 & 0.0004 & 0.05 & 3 & 0.0147 & 0.11 & 8 & 0.422 & 1.076 & 8 & 0.032 & 0.06 \\
\hline U-238 & 4 & 0.042 & 0.112 & 3 & 0.185 & 0.398 & 8 & 5.8 & 15.0 & 8 & 0.38 & 1.03 \\
\hline U-233/234 & 4 & 0.056 & 0.135 & 3 & 0.188 & 0.438 & 8 & 5.1 & 13.3 & 8 & 0.51 & 1.22 \\
\hline$Y-88$ & 4 & -1.05 & 2.32 & 3 & -0136 & 3.35 & 8 & 0.611 & 1.075 & 8 & 0.53 & 1.1 \\
\hline $\mathrm{Zn}-65$ & 4 & 1.09 & 4.27 & 3 & 0.019 & 3.8 & 8 & -1.08 & 0.91 & 8 & -2.12 & 1.24 \\
\hline Zr-95 & 4 & 2.02 & 5.17 & 3 & -1.59 & 5.9 & 8 & 1.06 & 2.6 & 8 & 0.22 & 1.61 \\
\hline
\end{tabular}


TABLE B5. Mean concentration $(\mu \mathrm{g} / \mathrm{L})$ and $95 \%$ upper confidence intervals of non-radiological constituents in surface water, 1996.

\begin{tabular}{|c|c|c|c|c|c|c|c|c|c|c|c|c|}
\hline \multirow[t]{2}{*}{ Constituent } & \multicolumn{3}{|c|}{ Background } & \multicolumn{3}{|c|}{ F-Area Seepline } & \multicolumn{3}{|c|}{ H-Area Seepline } & \multicolumn{3}{|c|}{ Fourmile Branch } \\
\hline & $\mathrm{n}$ & Mean & $95 \%$ UCI & $\mathrm{n}$ & Mean & $95 \%$ UCI & $\mathrm{n}$ & Mean & $95 \%$ UCI & $\mathrm{n}$ & Mean & $95 \% \mathrm{UCL}$ \\
\hline Antimony & 4 & 4.04 & 7.09 & 3 & - & $\overline{-}$ & 5 & - & - & 5 & - & - \\
\hline Arsenic & 4 & - & - & 3 & - & - & 5 & 4.63 & 5,65 & 5 & 5.49 & 6.84 \\
\hline Barium & 4 & 22.69 & 39.82 & 3 & 22.37 & 24.95 & 5 & 111.6 & 275.67 & 5 & 45.84 & 87.82 \\
\hline Beryllium & - & - & - & 3 & 2.03 & 6.21 & 5 & 0.84 & 2.42 & 5 & 0.08 & 0.14 \\
\hline Cadmium & 4 & 1.54 & 3.0 & 3 & 1.43 & 3.88 & 5 & 2.04 & 4,66 & 5 & 1.7 & 2.54 \\
\hline Chromium & 4 & 1.64 & 4.2 & 3 & - & - & 5 & 3.61 & 4,69 & 5 & 3.52 & 4.46 \\
\hline Cobalt & 4 & 0.89 & 1.57 & 3 & 1.8 & 6.62 & 5 & 10.53 & 35.6 & 5 & 2.2 & 4.12 \\
\hline Copper & 4 & 2.75 & 5.63 & 3 & 4.14 & 5.5 & 5 & 3.58 & 4.19 & 5 & 3.93 & $5.4 \dot{3}$ \\
\hline Cyanide & 4 & 2.26 & 2.76 & 3 & - & - & 5 & 7.12 & 12,02 & 5 & 6.59 & 10.47 \\
\hline Lead & 4 & - & - & 3 & - & - & 5 & 4.31 & 6.23 & 5 & 4.25 & 6.17 \\
\hline Mercury & 4 & 0.03 & 0.05 & 3 & 0.078 & 0.196 & 5 & 0.13 & 0.22 & 5 & 0.11 & 0.19 \\
\hline Nickel & 4 & - & - & 3 & 1.32 & 1.77 & 5 & 3.33 & 9.01 & 5 & 5.1 & 10.67 \\
\hline Selenium & 4 & - & - & 3 & 4.01 & 8.28 & 5 & - & - & 5 & - & - \\
\hline Silver & 4 & - & - & 3 & - & - & & 5 & - & - & 5 & - \\
\hline Thallium & 4 & - & - & 3 & 2.7 & 4.25 & 5 & 3.57 & 5.31 . & 5 & 4.46 & 5.97 \\
\hline Tin & 4 & - & - & 3 & - & - & 5 & - & - & 5 & - & - \\
\hline Vanadium & 4 & 3.73 & 10.52 & 3 & 3.63 & 17.34 & 5 & 7.7 & 12.69 & 5 & 8.01 & 16.89 \\
\hline Zinc & 4 & 3.58 & 5.49 & 3 & 6.29 & 18.68 & 5 & 36.7 & 112.25 & 5 & 5.26 & 7.08 \\
\hline
\end{tabular}

Note: Analytical results and statistics are preliminary. Additional results are expected in summer, 1997. 


\begin{tabular}{|c|c|c|c|c|c|c|c|c|c|c|c|c|}
\hline \multirow[t]{2}{*}{ Constituent } & \multicolumn{3}{|c|}{ Background } & \multicolumn{3}{|c|}{ F-Area Seepline } & \multicolumn{3}{|c|}{ H-Area Seepline } & \multicolumn{3}{|c|}{ Fourmile Branch } \\
\hline & $\mathrm{n}$ & Mean & $95 \% \mathrm{UCI}$ & $\mathrm{n}$ & Mean & $95 \%$ UCI & $\mathrm{n}$ & Mean & 95\% UCI & $\mathrm{n}$ & Mean & $95 \%$ UCL \\
\hline Ac- 228 & 4 & 5.12 & 8.90 & 5 & 4.13 & 7.49 & 5 & 4.97 & 8.74 & 3 & 3.08 & 5.24 \\
\hline Am-241 & - & $\therefore$ & - & - & - & - & 2 & 0.015 & 0.049 & - & - & - \\
\hline $\mathrm{Ba}-133$ & 4 & 0.059 & 2.28 & 5 & -0.17 & 0.77 & 5 & -0.92 & 0.009 & 3 & 0.98 & 4.01 \\
\hline Ce-144 & - & - & - & 5 & -1.43 & 7.99 & 5 & 2.18 & 11.66 & 3 & 5.08 & 9.81 \\
\hline $\mathrm{Cm}-242$ & - & - & - & - & - & - & 2 & -0.015 & 0.36 & - & - & - \\
\hline $\mathrm{Cm}-243 / 244$ & - & $\therefore$ & - & - & - & - & 2 & 0.11 & 0.42 & - & - & - \\
\hline $\mathrm{Cm}-245 / 246$ & - & - & - & - & - & - & 2 & -0.004 & 0.04 & - & - & - \\
\hline Co-57 & 4 & $0 . \grave{4} 8$ & 1.54 & 5 & 0.33 & 1.26 & 5 & -0.102 & 0.77 & 3 & 0.25 & 0.82 \\
\hline $\mathrm{Co}-58$ & - & - & - & 5 & 0.59 & 1.44 & 5 & -0.60 & 0.70 & 3 & 0.17 & 0.88 \\
\hline $\mathrm{Co}-60$ & 4 & 0.25 & 1.59 & 5 & 0.79 & 1.92 & 5 & 2.00 & 7.13 & 3 & 0.12 & 2.83 \\
\hline Cs- 134 & 4 & -2.10 & 1.87 & 5 & 0.36 & 1.40 & 5 & -0.05 & 1.14 & 3 & -0.56 & 2.93 \\
\hline Cs-137 & 4 & -0.17 & 1.35 & 5 & 0.94 & 3.07 & 5 & 0.12 & 0.83 & 3 & 5.46 & 15.61 \\
\hline Eu-152 & 4 & 0.62 & 9.89 & 5 & 1.13 & 3.42 & 5 & 0.29 & 3.05 & 3 & -0.26 & 5.08 \\
\hline Eu-154 & 4 & 0.90 & 8.71 & 5 & 2.00 & 5.68 & 5 & 0.62 & 3.43 & 3 & 1.62 & 2.37 \\
\hline Eu-155 & 4 & 3.32 & 10.83 & 5 & 0.07 & 3.39 & 5 & 1.95 & 5.78 & 3 & -1.78 & 4.26 \\
\hline Gross Alpha & 4 & 1.04 & 1.35 & 5 & 4.85 & 12.29 & 5 & 10.84 & 27.52 & 3 & 3.15 & 8.41 \\
\hline I -129 & - & $\therefore$ & - & 3 & 0.53 & 1.68 & 4 & 29.75 & 81.22 & - & - & - \\
\hline $\mathrm{K}-40$ & 4 & 22,9 & 34.05 & 5 & 19.08 & 32.97 & 5 & 23.98 & 34.83 & 3 & 9.47 & 8.33 \\
\hline $\mathrm{Pb}-212$ & 4 & 3.54 & 6.68 & 5 & 1.19 & 2.83 & 5 & 4.29 & 7.94 & 3 & 1.22 & 5.14 \\
\hline $\mathrm{Mn}-54$ & 4 & 0.40 & 1.88 & 5 & -0.81 & -0.48 & 5 & 0.15 & 1.02 & 3 & -0.19 & 0.59 \\
\hline $\mathrm{Na}-22$ & 4 & $0.32 !$ & 3.10 & 5 & 0.72 & 2.04 & 5 & 0.22 & 1.22 & 3 & 0.58 & 0.86 \\
\hline $\mathrm{Ni}-63$ & -- & - & - & 3 & 88.3 & 264 & 4 & 45.32 & 124.94 & - & - & - \\
\hline
\end{tabular}


TABLE B6. (Continued)Mean radioactivity ( $\mathrm{pCi} / \mathrm{L}$ ) and $95 \%$ upper confidence intervals (UCL) for radionuclides constituents in surface water

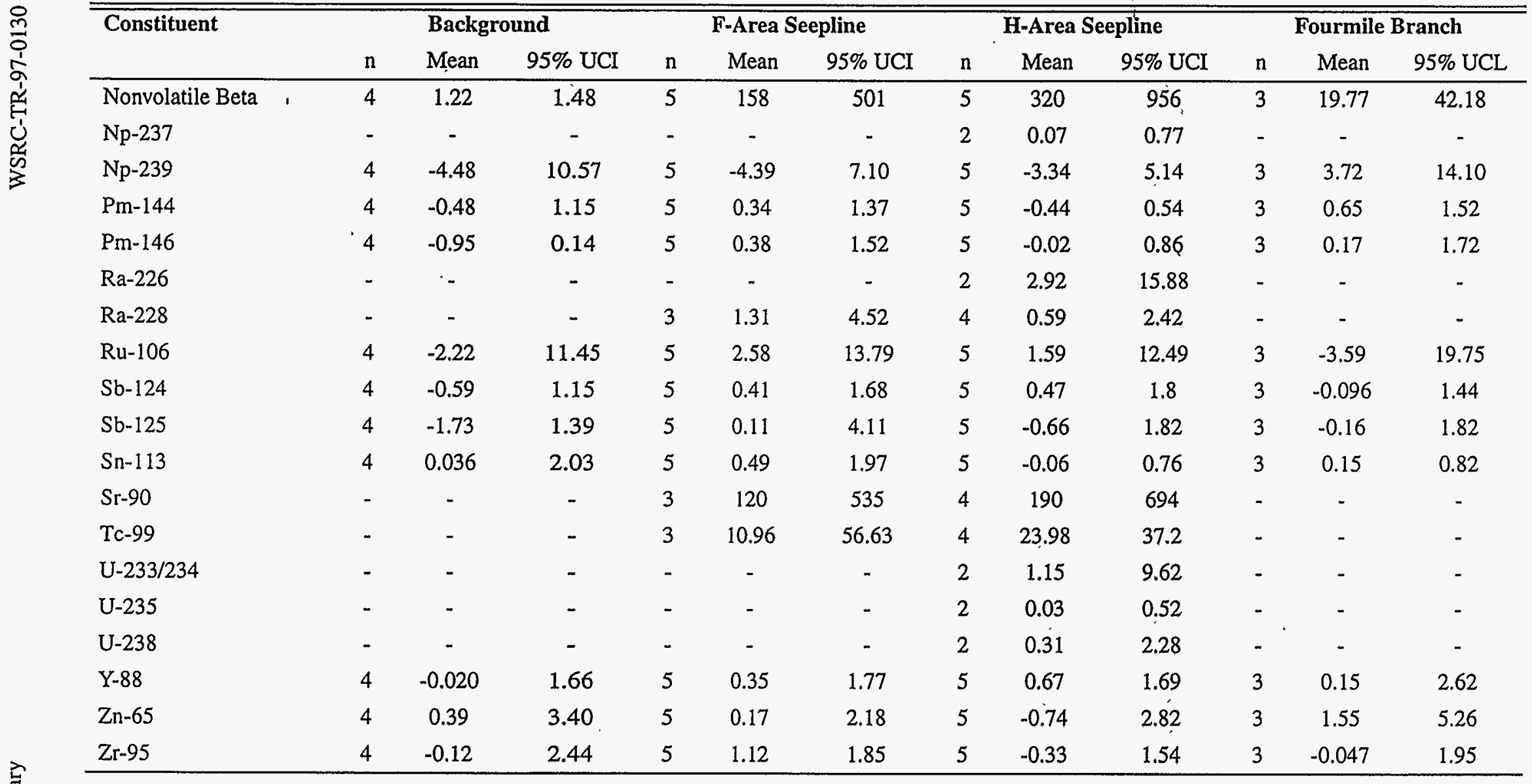

Note: Analytical results and statistics are preliminary. Additional results are expected in summer, 1997. 


\section{APPENDIX C}

Piezometer Data, January-August 1996 
TABLE C1. Construction information for the F- and H-Area wetlands piezometer network (Dixon 1996a).

\begin{tabular}{|c|c|c|c|c|c|c|c|c|c|c|c|c|c|}
\hline $\begin{array}{l}\text { Piezometer } \\
\text { No. }\end{array}$ & Latitude & Longitude & $\begin{array}{c}\text { Elevation } \\
\text { (ft) } \mathrm{msl}\end{array}$ & $\begin{array}{c}\text { Total } \\
\text { Drilled } \\
\text { Depth (ft) }\end{array}$ & $\begin{array}{c}\text { Top of } \\
\text { Casing (ft) } \\
\text { msl }\end{array}$ & $\begin{array}{c}\text { Casing } \\
\text { Height } \\
\text { (ft) }\end{array}$ & $\begin{array}{l}\text { Piczometer } \\
\text { Length (ft) }\end{array}$ & $\begin{array}{l}\text { Depth to } \\
\text { Screen (ft) }\end{array}$ & $\begin{array}{c}\text { Top of } \\
\text { Screen (f) } \\
\text { msl }\end{array}$ & $\begin{array}{c}\text { Total } \\
\text { Length of } \\
\text { Screen }^{*} \text { (ft) }\end{array}$ & $\begin{array}{l}\text { Length } \\
\text { of } \\
\text { Sump } \\
\text { Cap (ft) }\end{array}$ & $\begin{array}{l}\text { Length } \\
\text { of } \\
\text { Sump } \\
\text { (ft) }\end{array}$ & $\begin{array}{l}\text { Bottom of } \\
\text { Piczometer } \\
\text { Elevation }(\Omega)\end{array}$ \\
\hline FPZ001A & 33.26827 & 81.68141 & 197.9 & 16.31 & 200.06 & 2.16 & 18.47 & 13.39 & 184.51 & 2.5 & 0.4 & 0 & 181.59 \\
\hline FPZ002A & 33.26856 & 81.68131 & 201.2 & 12.27 & 203.41 & 2.21 & 14.48 & 9.35 & 191.85 & 2.5 & 0.4 & 0 & 188.93 \\
\hline FPZ003A & 33.26779 & 81.67972 & 194 & 21.53 & 196.97 & 2.97 & 24.5 & 6.11 & 187.47 & 15 & 0.4 & 0 & 172.47 \\
\hline FPZ004A & 33.27004 & 81.67879 & 203.1 & 11.56 & 205.94 & 2.84 & 14.4 & 8.64 & 194.46 & 2.5 & 0.4 & 0 & 191.54 \\
\hline FPZ005A & 33.2691 & 81.67832 & 190.9 & 14.72 & 192.78 & 1.88 & 16.6 & 11.8 & 179.1 & 2.5 & 0.4 & 0 & 176.18 \\
\hline FPZ005B & 33.2691 & 81.67832 & 190.9 & 6.95 & 192.88 & 1.98 & 8.93 & 1.95 & 188.95 & 5 & 0.4 & 0 & 183.95 \\
\hline FPZ006A & 33.26899 & 81.67781 & 189.4 & 14.3 & 191.54 & 2.14 & 16.44 & 11.38 & 178.02 & 2.5 & 0.4 & 0 & 175.1 \\
\hline FPZ006B & 33.26899 & 81.67781 & 189.4 & 7.7 & 191.6 & 2.2 & 9.9 & 2.7 & 186.7 & 5 & 0.4 & 0 & 181.7 \\
\hline FPZ007A & 33.26978 & 81.67679 & 194.5 & 10.67 & 196.16 & 1.66 & 12.33 & 7.75 & 186.75 & 2.5 & 0.4 & 0 & 183.83 \\
\hline FPZ007B & 33.26978 & 81.67679 & 194.5 & 5.4 & 196.4 & 1.9 & 7.3 & 0.4 & 194.1 & 5 & 0.4 & 0 & 189.1 \\
\hline FPZ008A & 33.27046 & 81.67588 & 187.4 & 16.96 & 189.54 & 2.14 & 19.1 & 14.04 & 173.36 & 2.5 & 0.4 & 0 & 170.44 \\
\hline FPZ008B & 33.27046 & 81.67588 & 187.4 & 10.5 & 189.6 & 2.2 & 12.7 & 3 & 184.4 & 7.5 & 0.4 & 0 & 176.9 \\
\hline HPZ001A & 33.27431 & 81.65869 & 202.4 & 15.37 & 204.78 & 2.38 & 17.75 & 7.45 & 194.95 & 5 & 0.4 & 2.5 & 187.03 \\
\hline HPZO02A & 33.27595 & 81.6582 & 218.8 & 12.07 & 220.88 & 2.08 & 14.15 & 6.65 & 212.15 & 5 & 0.4 & 0 & 206.73 \\
\hline HPZ003A & 33.27452 & 81.65636 & 200.4 & 17.62 & 202.53 & 2.13 & 19.75 & 14.7 & 185.7 & 2.5 & 0.4 & 0 & 182.78 \\
\hline HPZ003B & 33.27452 & 81.65636 & 200.4 & 7.43 & 202.8 & 2.4 & 9.83 & 2.43 & 197.97 & 5 & 0.4 & 0 & 192.97 \\
\hline HPZ004A & 33.27545 & 81.65605 & 210.7 & 14.09 & 213.56 & 2.86 & 16.95 & 11.17 & 199.53 & 2.5 & 0.4 & 0 & 196.61 \\
\hline HPZO05A & 33.27562 & 81.6549 & 213.8 & 9.89 & 215.66 & 1.86 & 11.75 & 6.97 & 206.83 & 2.5 & 0.4 & 0 & 203.91 \\
\hline HPZ005B & 33.27562 & 81.6549 & 213.8 & 6.21 & 215.4 & 1.6 & 7.81 & 1.21 & 212.59 & 5 & 0.4 & 0 & 207.59 \\
\hline HPZ006A & 33.27462 & 81.65424 & 201.7 & 9.41 & 205.29 & 3.59 & 13 & 3.99 & 197.71 & 5 & 0.4 & 0 & 192.29 \\
\hline $\mathrm{FMB} / \mathrm{C} 4$ & & & NA & NA & $186.55^{b}$ & NA & $\mathrm{NA}$ & NA & $\mathrm{NA}$ & $\mathrm{NA}$ & NA & NA & $\mathrm{NA}$ \\
\hline $\mathrm{FMB} / \mathrm{E} 1$ & & & $\mathrm{NA}$ & NA & 215.18 & NA & NA & $\mathrm{NA}$ & $\mathrm{NA}$ & $\mathrm{NA}$ & NA & NA & NA \\
\hline
\end{tabular}

${ }^{2}$ Slot size for all screens is 0.010 inches.

${ }^{b}$ Stream locations are marked with a steel rod. This is the elevation of the steel rod. 


\begin{tabular}{|c|c|c|c|c|c|c|c|c|c|}
\hline \multirow[t]{2}{*}{ Piezometer No. } & \multicolumn{8}{|c|}{ Water Level Elevations (ft) msl } & \multirow{2}{*}{$\begin{array}{l}\text { Ground Elevatior } \\
\text { (ft) } \mathrm{msl}\end{array}$} \\
\hline & January & February & March & April & May & June & July & August & \\
\hline FPZ001A & 198.01 & 198 & 197.99 & 197.98 & 197.94 & 197.96 & 197.96 & 198.02 & 197.9 \\
\hline FPZ002A & 201.65 & 201.47 & 201.83 & 201.6 & 201.36 & 201.35 & 201.23 & 201.8 & 201.2 \\
\hline FPZ003A & 189.52 & 189.11 & 190.41 & 188.87 & 187.35 & 187.96 & 187.07 & 190.15 & 194 \\
\hline FPZ004A & 201.59 & 201.42 & 201.72 & 201.59 & 201.36 & 201.35 & 201.26 & 201.57 & 203.1 \\
\hline FPZ005A & 191.23 & 191.24 & 191.26 & 191.19 & 191.08 & 191.12 & 191.13 & 191.18 & 190.9 \\
\hline FPZ005B & ND & ND & ND & ND & ND & 191.22 & 191.23 & 191.18 & 190.9 \\
\hline FPZ006A & 189.49 & 189.35 & 189.56 & 189.19 & 188.6 & 188.84 & 188.99 & 189.34 & 189.4 \\
\hline FPZ006B & ND & ND & ND & ND & ND & 188.5 & 188.87 & 189.04 & 189.4 \\
\hline FPZ007A & 193.19 & 193.04 & 193.2 & 192.96 & 192.66 & 192.83 & 192.94 & 193.12 & 194.5 \\
\hline FPZ007B & ND & ND & ND & ND & ND & 194.28 & 193.83 & 194.33 & 194.5 \\
\hline FPZ008A & 187.7 & 187.67 & 187.72 & 187.65 & 187.56 & 187.58 & 187.59 & 187.63 & 187.4 \\
\hline FPZ008B & ND & ND & ND & ND & ND & 187.55 & 187.58 & 187.59 & 187.4 \\
\hline HPZ001A & 202.37 & 202.35 & 202.36 & 202.35 & 202.05 & 202.23 & 202.25 & 202.3 & 202.4 \\
\hline HPZ002A & 218.58 & 218.4 & 218.89 & 218.69 & 218.17 & 218 & 217.93 & 218.5 & 218.8 \\
\hline HPZ003A & 199.07 & 201.11 & 201.23 & 201.01 & 200.42 & 200.81 & 201.23 & 201.26 & 200.4 \\
\hline HPZ003B & ND & ND & ND & ND & ND & 200.39 & 200.74 & 201.02 & 200.4 \\
\hline HPZ004A & 210.36 & 210.3 & 210.38 & 210.3 & 210.11 & 210.11 & 208.88 & 210.3 & 210.7 \\
\hline HPZ005A & 213.21 & 212.79 & 213.25 & 212.51 & 211.61 & 211.99 & 212.46 & 213.06 & 213.8 \\
\hline HPZ005B & ND & ND & ND & ND & ND & 211.91 & 213.75 & 213.05 & ' 213.8 \\
\hline HPZ006A & 201.77 & 201.74 & 201.78 & 201.7 & 201.53 & 201.76 & 201.83 & 202.09 & 201.7 \\
\hline $\mathrm{FMB} / \mathrm{C} 4$ & ND & 178.42 & 178.4 & 178.33 & 178.18 & 178.2 & 178.23 & 178.26 & NA \\
\hline FMB/E1 & ND & 214.56 & 214.7 & 214.6 & 214.37 & 214.41 & 214.3 & 214.47 & NA \\
\hline
\end{tabular}


TABLE C3. Water Level Measurements for the Period of January 1996 to August 1996 (Dixon 1996a).

\begin{tabular}{lccccc}
\hline \hline $\begin{array}{l}\text { Piezometer } \\
\text { Number }\end{array}$ & $\begin{array}{c}\text { Minimum } \\
\text { Water Level (ft) }\end{array}$ & $\begin{array}{c}\text { Maximum } \\
\text { Water Level (ft) }\end{array}$ & $\begin{array}{c}\text { Mean } \\
\text { Water } \\
\text { Level (ft) }\end{array}$ & $\begin{array}{c}\text { Standard } \\
\text { Deviation }\end{array}$ & $\begin{array}{c}\text { Water Level } \\
\text { Relative to } \\
\text { Ground } \\
\text { Elevation }\end{array}$ \\
FPZ001A & 197.94 & 198.02 & 197.98 & 0.03 & 0.08 \\
FPZ002A & 201.23 & 201.83 & 201.54 & 0.22 & 0.34 \\
FPZ003A & 187.07 & 190.41 & 188.81 & 1.24 & -5.19 \\
FPZ004A & 201.26 & 201.72 & 201.48 & 0.16 & -1.62 \\
FPZ005A & 191.08 & 191.26 & 191.18 & 0.06 & 0.28 \\
FPZ005B & 191.18 & 191.23 & 191.21 & 0.03 & 0.31 \\
FPZ006A & 188.6 & 189.56 & 189.17 & 0.33 & -0.23 \\
FPZ006B & 188.5 & 189.04 & 188.8 & 0.28 & -0.6 \\
FPZ007A & 192.66 & 193.2 & 192.99 & 0.19 & -1.51 \\
FPZ007B & 193.83 & 194.33 & 194.15 & 0.28 & -0.35 \\
FPZ008A & 187.56 & 187.72 & 187.64 & 0.06 & 0.24 \\
FPZ008B & 187.55 & 187.59 & 187.57 & 0.02 & 0.17 \\
HPZ001A & 202.05 & 202.37 & 202.28 & 0.11 & -0.12 \\
HPZ002A & 217.93 & 218.89 & 218.4 & 0.34 & -0.41 \\
HPZ003A & 199.07 & 201.26 & 200.77 & 0.74 & 0.37 \\
HPZ003B & 200.39 & 201.02 & 200.72 & 0.32 & 0.32 \\
HPZ004A & 208.88 & 210.38 & 210.09 & 0.5 & -0.61 \\
HPZ005A & 211.61 & 213.25 & 212.61 & 0.59 & -1.19 \\
HPZ005B & 211.91 & 213.75 & 212.9 & 0.93 & -0.9 \\
HPZ006A & 201.53 & 202.09 & 201.78 & 0.16 & 0.07 \\
FMB/C4 & 178.18 & 178.42 & 178.29 & 0.1 & NA \\
FMB/E1 & 214.3 & 214.7 & 214.49 & 0.14 & NA \\
\hline a Positive values indicate the water level is above ground elevation. Negative values indicate the water level is below ground elevation. \\
\end{tabular}

